Universidade de São Paulo

Escola Superior de Agricultura "Luiz de Queiroz"

Necessidade hídrica e resposta da cultura de lima ácida 'Tahiti' a diferentes níveis de irrigação

José Alves Júnior

Tese apresentada para a obtenção do título de Doutor em

Agronomia. Área de concentração: Irrigação e Drenagem

Piracicaba

2006 


\section{José Alves Júnior}

Engenheiro Agrônomo

\section{Necessidade hídrica e resposta da cultura de lima ácida 'Tahiti' a diferentes níveis de irrigação}

Orientador:

Prof. Dr. MARCOS VINÍCIUS FOLEGATTI

Tese apresentada para a obtenção do título de Doutor em Agronomia. Área de concentração: Irrigação e Drenagem

\section{Piracicaba}


Dados Internacionais de Catalogação na Publicação (CIP) DIVISÃO DE BIBLIOTECA E DOCUMENTAÇÃO - ESALQ/USP

\section{Alves Júnior, José}

Necessidade hídrica e resposta da cultura de lima ácida 'Tahiti' a diferentes níveis de irrigação / José Alves Júnior. - - Piracicaba, 2006.

100 p. : il.

Tese (Doutorado) - - Escola Superior de Agricultura Luiz de Queiroz, 2006. Bibliografia.

1. Crescimento vegetal 2. Evapotranspiração 3. Fruto - Qualidade 4. Irrigação localizada 5. Limão 6. Produção agrícola 7. Sistema radicular I. Título

CDD 634.334 
Ninguém mais duvida que para assegurar rentabilidade na fruticultura a irrigação é fundamental. Isso é especialmente verdadeiro nas regiões citrícolas do Estado de São Paulo e nas áreas de fruticultura do Vale do São Fransisco, onde se verifica um avanço espetacular de pomares com alta tecnologia. Na Flórida, Estados Unidos, quase $100 \%$ dos pomares são irrigados, apesar de a região mostrar-se tão chuvosa quanto São Paulo. Entretanto, há uns tantos pontos críticos, que devem ser atentamente observados por aqueles que planejam valer-se da irrigação para aumentar a rentabilidade de seus pomares. Por isso, este estudo foi realizado, no intuito de gerar novas informações para citricultura irrigada no Estado de São Paulo, contribuindo com a pesquisa permanente nesta área. (O Autor). 


\section{AGRADECIMENTOS}

À Deus, que me fez participante de sua filiação, inteligência, bondade e vida, nunca me abandonando nos momentos difíceis.

À meus pais, José Alves Neto e Maria José Moreira Alves, pela dedicação, inteligência, criação, fé e esforços para a formação moral e intelectual dos seus filhos, ofereço e dedico.

À meus irmãos, Rogério e Márcia, Simone e Gilmar, que me acompanharam de perto em todas as atividades, dando força e carinho; Aos meus sobrinhos, Lara Roberta, Rogério Júnior, Ana Clara e Paulo Roberto; Aos meus avós, Pedro e Isabel: Aos meus tios e primos, minha homenagem.

Ao Departamento de Engenharia Rural - e principalmente ao Programa de Pós-Gradução em Irrigação e Drenagem - ESALQ/USP, pela oportunidade concedida para realização deste trabalho.

Ao Professor Dr. Marcos Vinícius Folegatti, que além da amizade e orientação neste trabalho, proporcionou momentos fundamentais para a minha formação profissional.

Ao Professor Dr. Fernando Braz Tangerino Hernandez pela orientação na Iniciação Científica, amizade e pelos incentivos para realização deste trabalho.

A CAPES, pela concessão de bolsa de Mestrado durante 6 meses, a FAPESP, pela concessão de bolsa de Doutorado Direto durante 42 meses.

Aos Professores e Pesquisadores Dr. Cláudio Ricardo da Silva, Dr. Tonny José Araújo da Silva, Dr. Luís Fernando de Souza Magno Campeche e Ronaldo Antonio dos Santos, pela amizade e companheirismo durante toda a realização do trabalho.

Ao Grupo de Práticas em Irrigação e Drenagem - GPID, com quem sempre pude contar para a realização deste trabalho, nos momentos de avaliações.

A toda equipe do Programa de Pós-Graduação em Irrigação e Drenagem ESALQ/USP, professores, técnicos, secretárias e estudantes, que foram minha família durante a realização deste trabalho e também responsáveis pela minha formação profissional.

A todos os funcionários do Restaurante Universitário (RUCAS), Biblioteca, Sessão de Pós-Graduação e da Prefeitura do Campos "Luiz de Queiroz" em especial as secretárias, meus sinceros agradecimentos. 
Aos amigos de moradia, Gustavo, Fernando, Hector, Niceu, Juan, Miguel, Jovan, Cláudio, Moacir, Sérgio, Dolorice, Carol, Eroni e demais agregados, que assim como eu, seguirão suas vidas em busca de outras realizações; mas que levarão em suas memórias tudo que vivenciamos juntos... "Foram momentos inesquecíveis...".

A todos, que de uma forma ou de outra, direta ou indiretamente, contribuíram para a o sucesso deste trabalho, obrigado. 


\section{SUMÁRIO}

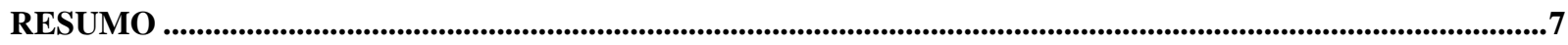

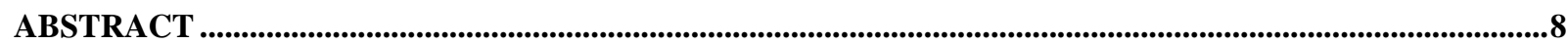

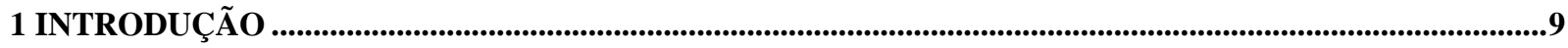

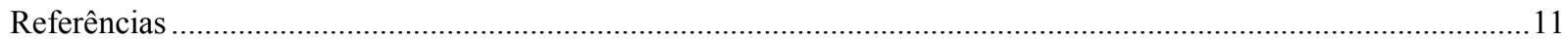

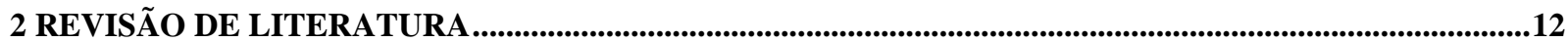

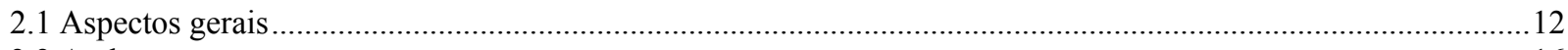

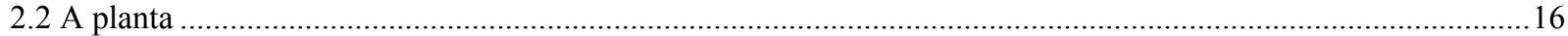

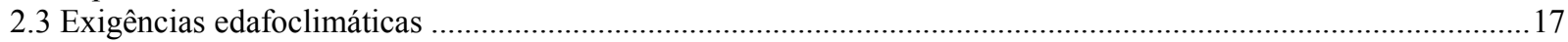

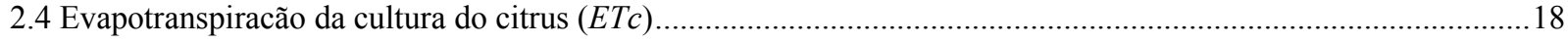

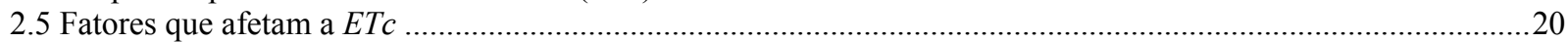

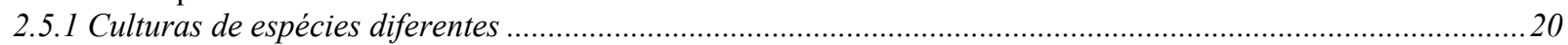

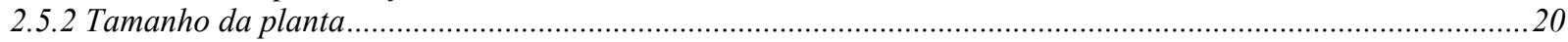

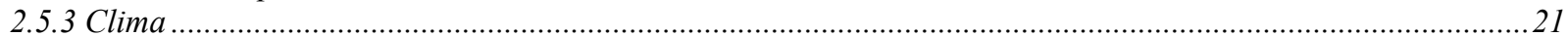

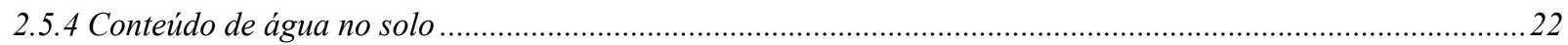

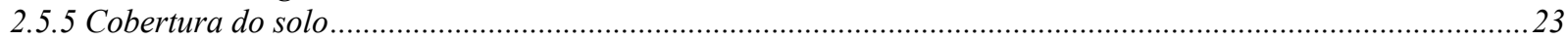

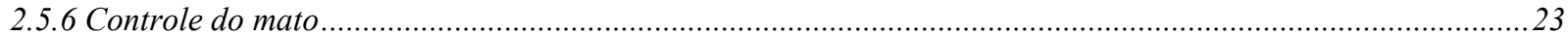

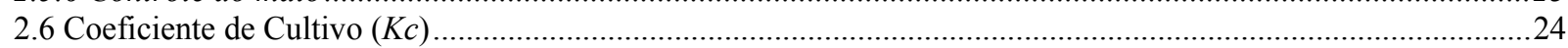

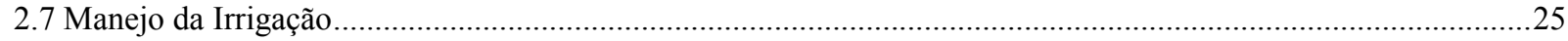

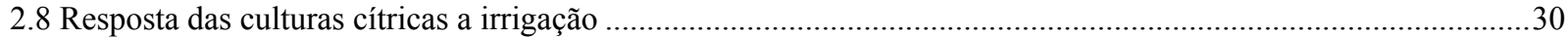

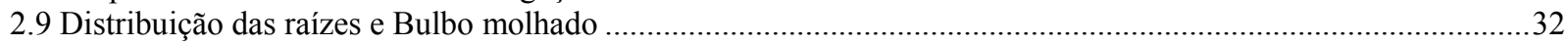

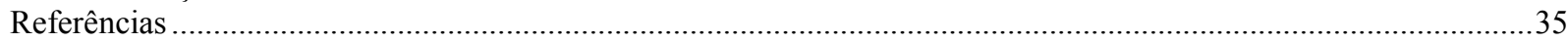

3 DETERMINAÇÃO DO COEFICIENTE DE CULTIVO PARA LIMA ÁCIDA 'TAHITI’ CULTIVADA EM

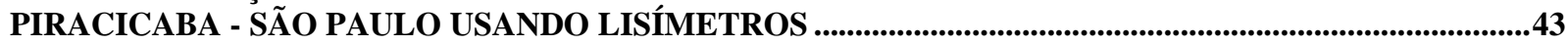

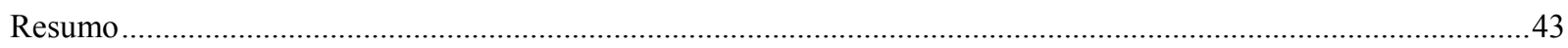

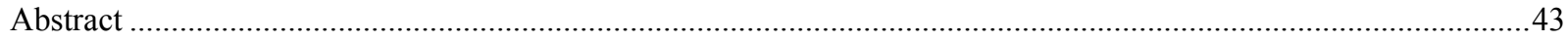

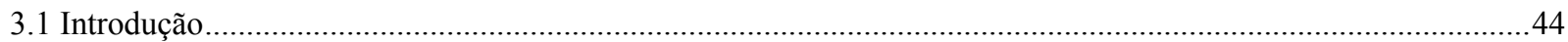

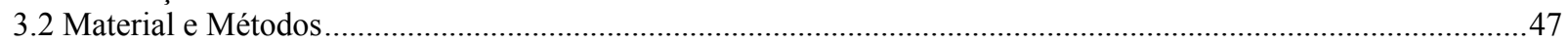

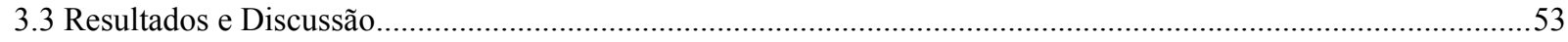

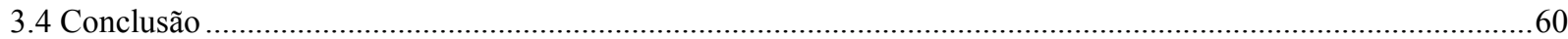

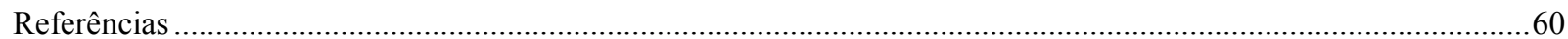

4 RESPOSTA DE PLANTAS JOVENS DE LIMA ÁCIDA 'TAHITI’ A DIFERENTES NÍVEIS DE

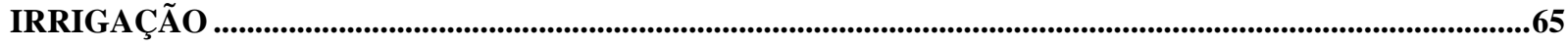

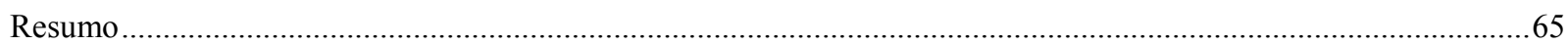

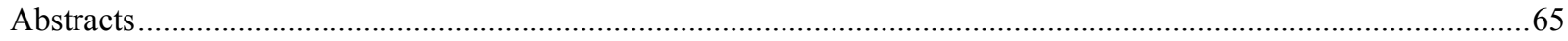

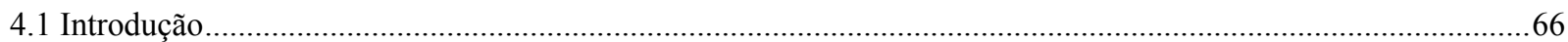

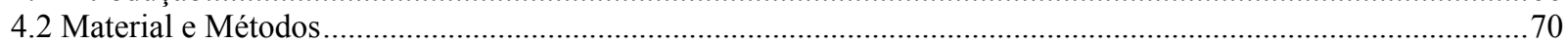

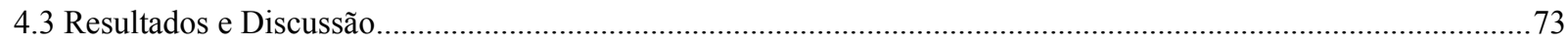

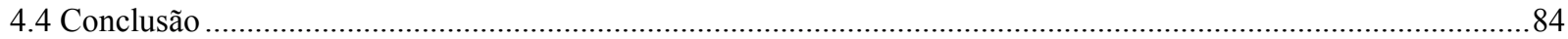

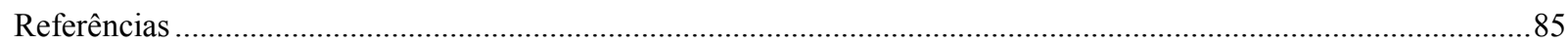

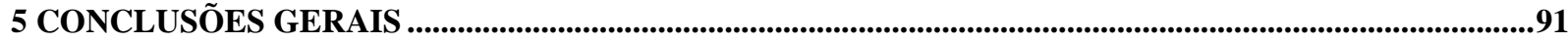

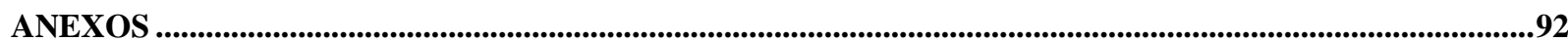




\title{
RESUMO \\ Necessidade hídrica e resposta da cultura de lima ácida 'Tahiti’ a \\ diferentes níveis de irrigação
}

\begin{abstract}
O Estado de São Paulo se destaca como uma das principais regiões produtoras de citros do mundo. Recentes estudos mostram que a área irrigada de citrus no Estado tem aumentado signicativamente nos últimos 5 anos. Porém, as limitações dos recursos hídricos e falta de informações sobre o manejo eficiênte da irrigação na cultura do citrus são os principais problemas face aos produtores. Visando atender essa necessidade, este projeto teve como objetivos determinar a evapotranspiração de uma planta jovem de limeira ácida 'Tahiti' (Citrus latifolia Tan.) e os coeficientes de cultivo durante a formação de um pomar. Considerando a independente contribuicão da evaporação do solo e transpiração da cultura pela substituição do coeficente de cultivo $(K c=E T c / E T o)$ em dois separados coeficientes; Ke, um coeficiente de evaporação de água do solo e $K c b$, um coeficiente de transpiração da cultura. Avaliar o desenvolvimento vegetativo, assim como aspectos produtivos da cultura, frente a diferentes níveis de irrigação, com o fornecimento crescente de 25 a $100 \%$ da necessidade hídrica da cultura. O experimento foi realizado na ESALQ/ USP em Piracicaba - SP, em uma área irrigada por gotejamento, com plantas espaçadas de $7 \times 4$ metros entre linhas e plantas respectivamente, sendo que cada planta foi atendida por 4 pontos de molhamento no solo distribuídos de forma eqüidistantes entre si. Foi avaliado o desenvolvimento vegetativo das plantas, com base em medidas de diâmetro do caule, altura e sistema radicular. Foi realizado o monitoramento climático utilizando estação meteorológica automatizada e a obtenção da evapotranspiração da cultura por lisímetro de pesagem. Durante o período de estudo, $K c$ variou entre 0,6 a 1,22, e $K c b$ variou entre 0,4 a 1,0. Os resultados mostraram que a independente influência da evaporação do solo e transpiração é importante para melhor compreensão sobre o consumo de água de plantas jovens de lima ácida 'Tahiti', quando comparado a plantas adultas. Os maiores consumos foram observados no verão. A reposição de $100 \%$ da água evapotranspirada resultou em melhor desenvolvimento vegetativo de plantas jovens de limeira acida 'Tahiti' em condições de campo. Os resultados mostraram também que não houve diferenças entre as lâminas quanto à distribuição das raízes, de plantas jovens (33 meses) em profundidade, concentrando-se na camada de 0,0 $0,3 \mathrm{~m}$. Entretanto, a distribuição horizontal foi maior nos níveis baixos $(0 \% ; 25 \%$ e $50 \%)$ do que nos maiores níveis $(75 \%$ e $100 \%)$. Nas plantas irrigadas com $75 \%$ e $100 \%$ houve concentração das raízes até $0,6 \mathrm{~m}$, indicando que o déficit hídrico induziu o crescimento na direção horizontal. E que a profundidade e distância horizontal efetiva das raízes, de plantas com 48 meses, localizam-se a $0,6 \mathrm{~m}$ de profundidade. Os resultados mostraram que a irrigação induziu à precocidade da produção e ao aumento da produtividade e do número de frutos nas plantas jovens de lima ácida 'Tahiti' já a partir da lâmina de $25 \%$ da evapotranspiração da cultura. Quanto à qualidade de frutos, não houve diferença significativa entre os níveis de irrigação avaliados.
\end{abstract}

Palavras-chave: Manejo da irrigacao; produtividade de citrus; qualidade de fruto; distribuicao de raizes; crescimento; evapotranspiracao; Citrus latifolia Tanaka; irrigacao; Kc; Kcb;irrigacao localizada 


\section{ABSTRACT \\ Water requirement and response of 'tahiti' acid lime trees to different irrigation levels}

The State of São Paulo is one of the most important producers of citrus of the world. Recent studies showed that during the last 5 years, there was a significant increase in the area with citrus irrigation. However, the shortage of water and the unavailability of required information for efficient irrigation scheduling are the main problems that producers face. Therefore, the objective of this work was an estimate water requirement of young 'Tahiti' lime orchards considering the independent contributions from soil evaporation and crop transpiration by splitting the crop coefficient $(K c=E T c / E T o)$ into two separate coefficients; $K e$, a soil evaporation coefficient and $K c b$, a crop transpiration coefficient. Evaluate the effect of different irrigation levels ( 0 to $100 \%$ of crop evapotranspiration by weighing lysimeter) on 'Tahiti' acid lime young tree canopy and root growth, productivity and quality of fruit, under drip irrigation in the field. The experiment was conducted during a 3-yr period (August 2002 - May 2005) in a 1.0 ha plot planted with 'Tahiti' acid lime trees, grafted on 'Swingle' citrumelo rootstock. The trees were 1-yr old at planting, spaced 7 x 4 m. The orchard was located in Piracicaba, São Paulo State, Brazil. Each treatment was assigned to different irrigation level, based on ETc as determined by a weighing lysimeter. The trunk diameter and height tree were evaluated monthly. The roots were evaluated when the trees were 30 and 48 months old. Adopted during the first root sampling were 4 horizontal distances from the tree trunk $(0.3,0.6,0.9$ and $1.2 \mathrm{~m})$ and 2 depths $(0.0-0.3$ and $0.3-$ $0.6 \mathrm{~m})$. Adopted during the second sampling were 5 horizontal distances from trunk $(0.3,0.6,0.9$, 1.2 and $1.5 \mathrm{~m})$, and 3 depths $(0.0-0.3,0.3-0.6$ and $0.6-0.9 \mathrm{~m})$. The yield was evaluated by measuring weight and number of fruits per tree in 2004 and 2005. The quality of the yield was evaluated by measuring fruit diameter, rind thickness, $\%$ of juice, total soluble solids, $\mathrm{pH}$ and total acidity. During the study period, $K c$ varied between 0.6 to 1.22 , and $K c b$ varied between 0.4 to 1.0. The independent influence of soil evaporation and transpiration is important to better understand the water consumption of young lime tree during the growth, compared to mature lime tree. The biggest ETC and $K c$ were observed on summer. The results showed that young trees irrigated with $100 \%$ ETc resulted in greater growth. The results also showed that did not happen differences in root distribution in the depths, most of them at $0-0.3 \mathrm{~m}$. However, the horizontal distribution at lower levels $(25$ and $50 \%$ ) of that in the biggest levels (75 and 100\%) that concentrated at $0.6 \mathrm{~m}$, indicating that water stress induced the root growth horizontally. The results, at the second analysis, showed that did not happen differences in root distribution soil profile, and effective depth and horizontal distance of root located to $0.6 \mathrm{~m}$ of depth and 0.6 of horizontally distant of tree. Finally, the irrigation induced precocity of production, increase of productivity and the fruits number already with irrigation of $25 \%$ of ETc. The quality of fruit, did not present difference among the treatments.

Keywords: Irrigation scheduling, citrus yield, fruit quality, root distribution, growth, Evapotranspiration; Citrus latifolia Tanaka;irrigation; Kc; Kcb; trikle irrigation 


\section{INTRODUÇÃO}

O Brasil é o maior produtor mundial de citros, respondendo pela produção de aproximadamente $35 \%$ de toda laranja obtida no mundo e de $85 \%$ das exportações de suco concentrado e congelado. Na safra de 2002/2003, foram produzidas aproximadamente 15,5 mil ton (380 milhões de caixas) de citros no Brasil, gerando uma renda de US\$ 1,5 bilhão (FNP, 2004). A irrigação de pomares de citros é uma prática cultural pouco utilizada em São Paulo, dos 651 mil hectares de citros plantados (ESTADOS UNIDOS, 2005), cerca de 15\% são irrigados (PARSONS, 2005). A tendência da citricultura brasileira é de aumento da produtividade, provocado pela forte expansão da irrigação nos pomares, prática comprovadamente vantajosa e que traz incremento importante de produtividade (FNP, 2003; DAVIES; ALBRIGO,1994). Nos poucos estudos que foram realizados, foram observados resultados econômicos significativos com a utilização da irrigação na cultura com aumento de produção de 35 a 75\% segundo citação de Vieira (1988). Além disso, a floração pode ser antecipada via irrigação diminuindo a incidência de doenças que coincidem no período chuvoso.

A irrigação pode melhorar a produtividade dos pomares, pois atende as necessidades hídricas da planta quando a quantidade média de chuvas é insuficiente a sua necessidade, a qual poderia limitar o rendimento ótimo da cultura. É comum a ocorrência de um déficit hídrico moderado no período de inverno em Piracicaba-SP, que talvez não justifica a necessidade de irrigação, entretanto as condições climáticas variam, como em 1994, onde esta ocorreu em uma intensidade maior o que prejudicou o rendimento da cultura naquele ano. Por isso, a irrigação pode ser encarada ainda como um seguro agrícola ao citricultor.

No Estado de São Paulo, maior produtor nacional, até pouco tempo atrás o interesse pelo citricultor em optar pela irrigação era pequeno, pois conseguiam a viabilidade da cultura apesar da produtividade ser baixa (ZANINI; PAVANI, 1998). No entanto, com a queda nos preços, a incidência de doenças como a Clorose Variegada dos Citros (CVC) cujo principal reflexo é a diminuição do tamanho do fruto, além da Gomose e por último a Morte Súbita do Citrus (MSC), que se manifesta em plantas 
enxertadas sobre limoeiro 'Cravo', o mais resistente às secas e por isso mais utilizado ( $85 \%$ da citricultura nacional), os novos pomares a partir de então, estão sendo feitos com uso de porta-enxertos tolerantes as essas doenças, mas menos tolerantes às secas, como a laranjeira 'Caipira' e as tangerinas 'Sunki', 'Cleópatra' e Citrumelo 'Swingle'. Com isso, a utilização da irrigação tem ganhado importância frente aos citricultores.

Entretanto, não basta apenas instalar o sistema de irrigação para o sucesso na prática da irrigação, isso está diretamente relacionado ao manejo adequado, fornecendo água ao solo no momento oportuno e na quantidade suficiente para atender as necessidades hídricas da planta. Pode-se dizer que este manejo tem os seguintes objetivos (SILVEIRA; STONE, 2001): a) maximizar a produtividade da cultura: de um modo geral, déficits de água em qualquer fase do desenvolvimento da planta, contribuem para reduzir o rendimento final da cultura e, até certos limites, tem-se verificado que este rendimento aumenta com a quantidade de água aplicada no solo; b) minimizar o uso de água e energia: há um gasto adicional de água e energia se houver irrigação além das necessidades hídricas da planta. Além disso, a água é um fator limitante e até conflitante em certas áreas de concentração de irrigação e o custo da energia mensal é proporcional à potência do conjunto moto-bomba e às horas de funcionamento; c) aumentar a eficiência de adubos: é sabido que a eficiência do adubo nitrogenado e, principalmente do fósforo, o qual se move por difusão, é maior em maiores umidades no solo; d) manter ou melhorar as condições químicas e físicas do solo: lixiviação de nutrientes, desagregação e erosão do solo podem ocorrer se a irrigação não for eficiente.

Portanto, estudos que buscam aumentar os conhecimentos técnicos da citricultura irrigada são muito importantes para manter a região como importante pólo produtor de citros.

Assim, este estudo teve como objetivos:

a) determinar a evapotranspiração de uma planta jovem de limeira ácida 'Tahiti' e estimar os coeficientes de cultivo durante a formação do pomar usando a técnica da lisimetria de pesagem; 
b) avaliar o desenvolvimento vegetativo, a partir de altura de planta e diâmetro de caule;

c) avaliar a distribuição do sistema radicular do porta enxerto citrumelo 'Swingle' sob a variedade de lima ácida 'Tahiti' IAC 5, em condições de sequeiro e irrigado sob diferentes tamanhos de bulbo molhado;

e) avaliar a produtividade e qualidade de fruto de lima ácida 'Tahiti' (Citrus latifolia Tan.), frente à níveis crescentes de irrigação, com o fornecimento de 0 a $100 \%$ da necessidade hídrica da cultura.

\section{Referências}

DAVIES, F.S.; ALBRIGO, L.G. Citrus. Wallingford: CAB International, 1994. 254 p.

ESTADOS UNIDOS. Department of Agriculture. Foreing Agriculture Service. Brazil Citrus: annual report 2005. Gain report BR5026. Global Agriculture Information Network. Disponivel em: http://www.fas.usda.gov/gainfiles/200512/146131807.doc Acesso em: 7 Mar. De 2006.

FNP CONSULTORIA \& AGROINFORMATIVOS. Agrianual 2003: anuário da agricultura brasileira. São Paulo, 2003. p. 295-331.

FNP COSULTORIA \& AGROINFORAMTIVOS. Agrianual 2004: anuário da agricultura brasileira. São Paulo, 2004. p. 496.

PARSONS, L.R. Weather and irrigation for the new year. Citrus Industry, Tampa, v.1, n.1, p.16-17, Jan./Feb. 2005

SILVEIRA, P.M.; STONE, L.F. Irrigação do feijoeiro. Goiânia: Embrapa Arroz e Feijão, 2001. 230 p.

VIEIRA, D.B. Fertirrigação e manejo de irrigação em citros. Laranja, Coordeirópolis, v. 2, n. 9, p. 369-376, 1988.

ZANINI, J.R.; PAVANI, L.C. Irrigação em citros. In: SEMINÁRIO INTERNACIONAL DE CITROS, 5., 1998, Bebedouro. Anais ... Campinas: Fundação Cargill, 1998. p. 409-442. 


\section{REVISÃO DE LITERATURA}

\subsection{Aspectos gerais}

No Brasil, em grande parte do seu território, a quantidade média de chuvas é insuficiente para atender às necessidades das plantas cítricas. Sua distribuição irregular propicia a ocorrência de longos períodos de déficit hídrico no solo e conseqüentemente estresse hídrico às plantas, gerando grandes quebras de produção (VIEIRA, 1991). Mesmo assim, apresenta-se como um dos maiores produtores mundiais de limão, apesar da citricultura brasileira ainda só explorar metade do seu potencial. A prova disto, é que nos últimos anos a importação de frutas apresentou-se 10 vezes maior que a exportação. Cerca de 850 mil toneladas de frutas saíram do país em 2004, número que cresceu 5\% em relação a 2003 e que fez o setor frutífero alcançar o recorde nas exportações, segundo informações do Instituto Brasileiro de Frutas (Ibraf). A citricultura representa quase a metade dessa produção, correspondendo 49\% do volume (NEVES et al., 2004).

As exportações brasileiras de 'Tahiti' in natura aumentaram significativamente nas últimas décadas. O volume total de limões e limas ácidas exportado, segundo a Food and Agriculture Organization (2003), saltou de apenas 0,9 mil t em 1971 para cerca de 3,8 mil t em 1991. A partir de 1999, os incrementos nessa pauta foram ainda maiores, chegando, em 2001, a um volume de 14,8 mil t de frutos, o que correspondeu a cerca de US\$ 7,6 milhões em divisas para o País, situando-o entre as dez variedades de frutas mais importantes no Brasil (IBGE, 2003).

A Lima ácida 'Tahití' (Citrus latifolia Tanaka) é, dentre as espécies cítricas, a de maior precocidade, apresentando, em geral uma produção significativa já a partir do terceiro ano, mas, só a partir do quinto em diante é que começa a expressar rendimentos econômicos. No Estado de São Paulo, essa cultura se adapta bem em quase todas as regiões, com exceção para aquelas onde a carência térmica limita o seu desenvolvimento. No total de 50 mil ha cultivado com limão no Brasil, o Estado de São Paulo detém cerca de 36 mil ha, produzindo 609 mil toneladas, aproximadamente $82 \%$ de um total de 742 mil toneladas produzidos nacionalmente (FNP, 2003). 
Essa importância expressiva da citricultura brasileira na economia do País faz com que a pesquisa, na cultura, seja realizada de forma permanente. Tudo isso, para viabilizála em novas áreas, aumentar a produtividade e qualidade da produção nas áreas já cultivadas, tornando-a cada vez mais competitiva no mundo globalizado. A produtividade de um pomar pode variar de safra para safra em função do manejo adotado pelos produtores e também pelo uso de tecnologia. Por isso, uma das alternativas que tem valorizado o setor citrícola é a irrigação, tecnologia cada vez mais necessária ao agronegócio que conta com as vantagens da modernidade favorecendo a lucratividade para o empresário rural. Entretanto, a lucratividade do pomar está ligada à competência de se produzir os frutos na época da entre safra (setembro a dezembro). Suspeita-se que com o uso da irrigação, se consiga alterar o período ou a longevidade da colheita. Mas, devido à falta ou a pouca disponibilidade de informações de estudos ligados à necessidade hídrica da cultura, que se propôs esse estudo, no intuito de obter resultados sobre a cultura irrigada na região. A falta de informações técnicas sobre limoeiro irrigado, dificulta a aceitação dessa tecnologia pelos produtores, que polpa os investimentos e isso muitas vezes os levam a um descrédito da cultura devido retornos econômicos insuficientes.

O uso da irrigação na citricultura brasileira não é uma prática nova. A novidade está no crescimento em São Paulo, região que responde por cerca de $80 \%$ da produção brasileira e é considerada a última fronteira citrícola do mundo com produção em larga escala ainda sem irrigação. A técnica da irrigação associada ao aumento de produtividade não tem sido mais o único aspecto estimulante para o produtor. $\mathrm{O}$ uso da irrigação também é uma alternativa para a diversificação de variedades de porta-enxertos principalmente nas regiões com alto déficit hídrico. A adoção de novos porta-enxertos nessas áreas, em substituição principalmente ao Limão Cravo, e o uso da subenxertia, recomendadas pelo Fundecitrus como tática para enfrentar a Morte Súbita do Citrus (MSC), são algumas das razões responsáveis pelo crescimento das áreas irrigadas. Há cinco anos, a área de citros irrigada em São Paulo não passava de 15 mil hectares. A estimativa é de que alcance 90 mil hectares e continue a crescer. O parque citrícola paulista atual é de 650 mil hectares. Estudos realizados pelo Fundecitrus e a 
Universidade de São Paulo (USP) mostraram uma expansão das áreas irrigadas no Brasil de 1,5\%, em 1999, para 10,2\%, em 2003. Muitos consultores de citros afirmam que a MSC alterou a percepção dos produtores sobre o uso da irrigação. A diversificação de porta-enxertos, com a adoção de variedades tolerantes a MSC, mas menos resistente à seca, aqueceu a demanda por sistemas de irrigação. $\mathrm{O}$ aspecto da produtividade também é muito relevante. Áreas irrigadas, com pomares adensados com 350 plantas por hectare, podem produzir mais de três caixas por planta, alcançando 40 a 50 toneladas do fruto por hectare por ano. A média de produção em São Paulo varia entre 2,2 caixas a 2,5 caixas por hectare. A irrigação se utilizada de forma correta pode assegurar boa produção, mas faz com que a citricultura entre num novo ciclo de acomodação de custos. O custo médio da irrigação localizada por hectare oscila entre US\$1,7 mil a US\$ 1,8 mil. Somado ao custo de manutenção, o prazo estimado para amortização total do sistema pode chegar a uma década. O valor de sistemas de irrigação por aspersão é menor na instalação (aproximadamente US\$ 1,1 mil/ha), mas em compensação, é maior na manutenção. No fim, ambos se equivalem em tempo de amortização. O peso, portanto, pode ser o custo econômico da água. Segundo dados do Departamento de Águas e Energia Elétrica (DAEE) o Comitê das Bacias Hidrográficas do Baixo Pardo Grande (CBH-BPG) já mediou conflitos nos municípios de Guaíra e Barretos. O avanço da citricultura irrigada na região já é fator de preocupação. O consumo é cinco vezes maior que o da indústria e das áreas residenciais juntas. O conflito pelo uso da água na região pode se acirrar no futuro por conta do avanço da irrigação. Em algumas regiões tem-se pouca água para irrigação. O próprio DAEE tem limitado a concessão de outorgas. O uso da irrigação localizada, considerada mais eficiente no consumo de água, minimiza os gastos. Estima-se que $65 \%$ das áreas irrigadas adotam sistemas de microaspersão ou gotejamento e apenas 35\% com aspersão. A escassez de água no norte de São Paulo é parte da razão que tem feito a citricultura se afastar da região Norte e se deslocar para região Sul do Estado (BRITO, 2004).

Dessa maneira, conhecer o consumo de água das plantas é um dos fatores fundamentais para se obter sucesso em investimentos na citricultura. Em cultivos de sequeiro é importante conhecer o regime pluviométrico da região para o planejamento 
agrícola. Este deve ser suficiente para suprir a demanda hídrica do pomar e tornar o empreendimento mais seguro. Em áreas irrigadas, essa informação passa a ter uma importância ainda maior, com destaque para três pontos. $\mathrm{O}$ primeiro é em relação à aquisição do direito pelo uso das águas, tanto de mananciais como de aqüíferos, através da outorga concedida pela Secretaria de Recursos Hídricos, em que só é obtida pelo irrigante mediante ao consumo de água da cultura a ser irrigada. Diante disso, em bacias já com conflito pelo uso da água, a informação do verdadeiro consumo pelas plantas ajudará em uma melhor gestão dos recursos hídricos. Ainda mais por ser a agricultura irrigada responsável pelo maior consumo de água das bacias. O segundo é quanto ao dimensionamento dos sistemas de irrigação. Essa informação é fundamental para se ter precisão nos cálculos e projetos de menor custo. A irrigação é uma técnica consagrada na agricultura por proporcionar um aumento de produtividade e qualidade da produção, além de possibilitar produção fora de época e etc. Porém, trata-se de uma técnica que aumenta o custo de produção e, em muitos casos, seu uso torna-se inviável. O conhecimento do real consumo de água pelas plantas poderá aumentar a viabilidade da irrigação por diminuir custos nos projetos (tubulações com diâmetros menores, conjuntos motobombas com menor potência etc). E, por último, o terceiro ponto, o qual permite ainda fazer um manejo correto da irrigação, proporcionando diminuição do consumo de água, energia elétrica e insumos. A prática de se determinar o consumo de água das plantas, é algo restrito à pesquisa. Sendo assim, faz-se uma estimativa do consumo, tanto para a aquisição da outorga de uso de água, como para o dimensionamento de sistemas de irrigação, assim como para o manejo correto da água aplicada. Esta estimativa, se feita de forma incorreta, pode provocar graves conseqüências (ALVES JUNIOR et al., 2004a).

A estimativa do consumo de água das plantas de uma forma geral é feita a partir da evapotranspiração de uma cultura de referência (ETo). Uma área gramada, ou melhor, uma cultura hipotética que cobre totalmente o solo, com altura constante e sem restrição hídrica. Partindo-se daí, estimam-se o consumo de água de qualquer cultura a partir da correção por fatores gerados pela pesquisa, conhecidos como coeficientes de cultivo 
$(K c)$, que transformam o consumo de referência obtido nas condições climáticas locais, em consumo da cultura nos seus diferentes estágios fenológicos (ALLEN et al., 1998).

Os coeficientes de cultivo também são divulgados pelo boletim da FAO 56 como uma aproximação para diversas culturas. O uso desses coeficientes no Brasil pode estimar o consumo de água pelas plantas de forma não satisfatória, por não terem sido obtidos nas condições edafoclimáticas locais. Portanto, estudos de consumo de água devem ser realizados em condições brasileiras no intuito de se obter dados mais confiáveis e que melhor representem a situação da cultura no Brasil.

\subsection{A planta}

A limeira ácida 'Tahiti' (Citrus latifolia Tanaka) é uma planta de tamanho médio a grande, vigorosa, expansiva, curvada, e quase sem espinhos. De origem tropical, o limão 'Tahiti' não é na verdade um limão verdadeiro, mas sim uma lima ácida, de folhagem densa, com folhas de tamanho médio, lanceoladas e com pecíolos alados. A floração ocorre durante quase todo ano, principalmente nos meses de setembro a outubro. Os frutos apresentam tamanho médio, ovais, oblongos ou levemente elípticos com a base usualmente arredondada. O suco, ácido, representa cerca de $50 \%$ do peso do fruto, com teores médios de brix $9 \%$, acidez $6 \%$, relação SST/acidez de 1,5 e o teor de ácido ascórbico varia entre 20 e $40 \mathrm{mg} / 100 \mathrm{ml}$ (PASSOS et al., 1977; FIGUEIREDO, 1986; MARCONDES, 1991).

O desenvolvimento vegetativo dos citros é influenciado pela temperatura do ar. As plantas brotam em qualquer época do ano, desde que a temperatura do solo esteja acima de $12{ }^{\circ} \mathrm{C}$ (AGUSTÍ ; ALMELA, 1991 apud MEDINA, 2003). A área foliar de uma planta adulta situa-se entre 100 e $200 \mathrm{~m}^{2}$ e o índice de área foliar (IAF) entre 1 e 4 $\mathrm{m}^{2}$, sendo maior nas regiões subtropicais, onde as plantas são mais compactas. Nas tropicais, os internódios são maiores e a folhagem, menos compactas (Grupo de Trabalho de Bioclimatologia RIAC, 2002 apud MEDINA, 2003).

O rendimento de pomares comerciais variam de acordo com a fase de produção: 8 a $15 \mathrm{~kg}$ com três anos de idade; 23 a $37 \mathrm{~kg}$ com quatro anos de idade; 64 a $86 \mathrm{~kg}$ com cinco 
anos; de 68 a $141 \mathrm{~kg}$ com seis anos. Aos 11 anos, a produtividade alcança $113 \mathrm{~kg}$ ou aproximadamente 400 mil frutos hectare. A produtividade média da Lima Ácida 'Tahiti' no Brasil situa-se por volta de $15 \mathrm{t} \mathrm{ha}^{-1}$ que está muito abaixo de $40 \mathrm{t} \mathrm{ha}^{-1}$ atingida em bons pomares do país (COELHO, 1993).

O destino da produção é o consumo in natura, nos mercados interno e externo ou para suco concentrado. O óleo essencial extraído da casca tem grande emprego industrial como aromatizante de alimentos e ingrediente de perfumaria. Além disso, apresenta propriedades medicinais, como estimulante da digestão, antioxidante e anti-séptico, tendo amplo uso nas formulações homeopáticas (LUCHETTI et al., 2003).

Em geral, as plantas cítricas desenvolvem-se em regiões de clima subtropical, quando as baixas temperaturas no inverno induzem a uma dormência e a um período de diferenciação floral seguido de um intenso florescimento na primavera. Porém, em condições de clima tropical, o florescimento é influenciado naturalmente pela sucessiva ocorrência de período de chuva e seca (PIRES et al.,1993). Estudos anatômicos e morfológicos estabeleceram que a diferenciação ocorre durante o período de estresse (NIR et al., 1972) e que neste período, ocorre um acúmulo de reservas que são rapidamente metabolizadas durante o florescimento das estruturas reprodutivas.

No caso de lima ácida 'Tahiti', Sentelhas et al. (1997), utilizando um método agrometeorológico de estimativa da época mais adequada para indução floral, identificaram diversos períodos médios de tempo de antecedência com que a indução floral deve ser feita para que a colheita ocorra com a entressafra (outubro e novembro). A duração média entre o florescimento e a maturação variou de 127 a 327 dias, para as colheitas de 15 de outubro, e de 107 a 294 dias, para as colheitas em 15 de novembro.

\subsection{Exigências edafoclimáticas}

A limeira ácida 'Tahiti', como as demais plantas cítricas, se adaptada bem a diferentes tipos de solo, desde muito arenoso a relativamente argiloso. Os solos mais adequados são os leves (areno argiloso), bem arejados, profundos e sem impedimentos. Para o Estado de São Paulo, os índices de boa fertilidade dos solos são: teor de matéria 
orgânica entre 1,5 e 4\%, pH medido em resina entre 14 e 40 ppm, potássio entre 0,2 e $0,3 \mathrm{mg} / 100 \mathrm{ml}$; cálcio entre 1,5 e 4,5 mg/100 ml e magnésio entre 0,5 e 1,5 mg/100 ml (GAYET, 1991).

No Brasil a concentração da citricultura no Estado de São Paulo deve-se, além das condições edafoclimáticas favoráveis, aos fatores culturais e bom suporte tecnológico agrícola e industrial. O clima interfere de forma decisiva em todas as etapas da cultura, influenciando na adaptação das variedades, no comportamento fenológico, na curva de maturação, na taxa de crescimento, nas características físicas e químicas da fruta e no potencial de produção. Dentre os elementos climáticos, a temperatura é o de maior importância, não apenas pela influência que exerce sobre o desenvolvimento das plantas e qualidade dos frutos, mas também por impor limites à expansão da cultura. Como a maioria das espécies do gênero Citrus, a limeira ácida 'Tahiti', sob temperaturas constantes, na faixa de 12 a $13{ }^{\circ} \mathrm{C}$, tem seu crescimento paralisado. Na faixa de 25 a $31{ }^{\circ} \mathrm{C}$, seu crescimento alcança a taxa máxima, detendo-se, contudo, sob temperatura acima de $39{ }^{\circ} \mathrm{C}$. A temperatura condiciona também o amadurecimento dos frutos (ORTOLANI et al., 1991).

\subsection{Evapotranspiracão da cultura do citrus (ETc)}

Como qualquer espécie, o fator hídrico desempenha papel fundamental no crescimento, desenvolvimento e produção vegetal dos citros.

A aplicação adequada de água às plantas cítricas é necessário para assegurar a floração, o pegamento, crescimento e qualidade dos frutos (COELHO et al., 2004). O déficit hídrico afeta o desenvolvimento radicular (SHALHEVET; LEVY, 1990), diminui a fotossíntese, promove a queda de folhas e frutos (REID, 1987 apud por MEDINA, 2003), aumento da concentração de sólidos solúveis e de acidez do suco (CRUSE et al., 1982 apud por MEDINA, 2003). Por outro lado, o excesso de água no solo ou o encharcamento do mesmo causa redução no crescimento e desenvolvimento das plantas em conseqüência dos danos às raízes. $\mathrm{O}$ efeito do encharcamento depende principalmente da temperatura do solo. Encharcamento no solo durante três dias 
consecutivos, para a temperatura na faixa de $30-35{ }^{\circ} \mathrm{C}$, é suficiente para matar as raízes dos citros que podem por sua vez sobreviverem durante meses a temperaturas do solo inferiores a $15{ }^{\circ} \mathrm{C}$ (COELHO et al., 2004).

As plantas cítricas apresentam uma capacidade de conservação de água devido à elevada resistência estomática e à cerosidade das folhas, além disso quando a demanda evapotranspirométrica aumenta, os estômatos tendem a se fechar reduzindo a transpiração (MILLS et al., 1999). Desta forma, quando ocorre uma mudança nas condições do ambiente em termos de aumento de radiação líquida e das diferenças entre a pressão de vapor nas folhas e no ar, a planta responde aumentando a resistência estomática. Assim, tem-se verificado comportamento semelhante de demanda de água por plantas cítricas em regiões úmidas e em regiões secas (COELHO et al., 2004).

As plantas mais jovens armazenam menor quantidade de água que as plantas adultas e apresentam menor capacidade de fechamento dos estômatos para reduzir a perda de água e menor cerosidade nas folhas, além de um sistema radicular menos volumoso, o que as torna mais sensíveis a déficits de água no solo (COELHO et al., 2004).

À semelhança do que ocorre com as culturas agrícolas em geral, as necessidades de água dos citros varia conforme o estádio fenológico das plantas. Na brotação, emissão de botões florais, frutificação e início de desenvolvimento dos frutos há maior demanda de água e as plantas são muito sensíveis ao déficit hídrico nesse período, sendo que o aumento no tamanho dos frutos está altamente relacionado com a absorção de água. $\mathrm{Na}$ fase de maturação, colheita e semi-dormência a demanda hídrica é menor. O período mais crítico vai da brotação até o fruto atingir $2,5 \mathrm{~cm}$ de diâmetro (COELHO et al., 2004).

Doorenbos e Kassam (1994) recomendam a lâmina entre 900 e 1200mm para maximizar a produtividade das plantas cítricas. Luchiari (2003) relata que no caso da irrigação complementar, tem-se aplicado de 400 a $600 \mathrm{~mm}$ de água por ano. Nas regiões citrícolas do Estado de São Paulo é comum à adoção de lâmina média de $120 \mathrm{~mm} / \mathrm{mês}$.

Parsons e Morgan (2004) relatam que o consumo de água das plantas cítricas depende do tamanho da planta, idade, espaçamento, podendo variar de 30 a 300 Litros 
por planta dia. Plantas adultas com baixa densidade de plantio são normalmente maiores e consome mais água. Na Flórida pomares com 355 plantas por hectare, do inverno para o verão, consomem de 53 a $148 \mathrm{~L}_{\text {planta }}{ }^{-1}$ dia $^{-1}$, enquanto que, pomares com 555 plantas por hectare consomem de 34 a 95 litros planta ${ }^{-1}$ dia $^{-1}$. As irrigações são normalmente realizadas por gotejadores que possuem vazão variando de 2 a 8 litros por hora, ou por microaspersores que variam vazão de 25 a 100 Litros por hora.

\subsection{Fatores que afetam a ETc}

\subsubsection{Culturas de espécies diferentes}

As plantas cítricas são culturas perenes e com vegetação permanente e transpiração durante todo ano. Koo (1963) e Koo e Sites (1955) relataram que o requerimento de água de grapefruit são geralmente maior quando comparado as variendades de laraja ou mandarin para plantas de igual tamanho. Wiegand e Swanson (1982 a, b, c) e Wiegand et al. (1982) relataram que a média diária de ETc de citrus em Weslaco, Texas variou de 2,2 a 3,3 mm para grapefruit 'Ruby red' e 1,9 a 2,7 mm para laranja 'Marrs' de 5 a 10 anos de idade.

Em condições climáticas similares é sabido que plantas cítricas têm menores taxas de transpiração quando comparada com outras culturas. Mahrer e Rytwo (1991) relataram estimativa média diária de ETc para milho com cobertura total do solo em Beltsville, Maryland (USA) de 3,8 a 5,0 mm e 5,2 a 8,0 mm antes e depois da chuva, respectivamente. Menores taxas de transpiração de citrus são explicados devido menor condutância da folha e copa (MILLS et al., 1999).

\subsubsection{Tamanho da planta}

Plantas adultas grandes, vigorosas e saudáveis requerem mais água quando comparado com plantas jovens (TUCKER et al., 1997). Na Florida, árvores grandes e com baixa densidade de plantido (150 a 180 árvores por ha) pode usar 62 a 94 L de água por dia durante os meses de inverno (Dezembro e Janeiro) e 189 a 219 L por dia no 
Verão (Julho e agosto) (BOMAN, 1994). Rogers e Bartholic (1976) relataram uma média anual de ETc de $1210 \mathrm{~mm}$ durante um período de 8 anos de um pomar jovem de laranja e grapefruit em solo mal drenado próximo a costa leste da Flórida. Estes valores anuais de ETc variaram de $820 \mathrm{~mm}$ no ínicio do estudo (árvores com 2 anos de idade) a $1280 \mathrm{~mm}$ no final do estudo (árvores com 10 anos de idade). Regressões lineares de ETc anual vs. anos de estudo resultaram em um significante $(\mathrm{P}>0.01)$ incremento de ETc. Média anual de ETc incrementou em uma taxa de $19 \mathrm{~mm}$ por ano ou incremento acumulado de aproximadamente 13\% em 8 anos. Fares e Alva (1999) relataram um anual valor de ETC de $920 \mathrm{~mm}$ para plantas de 'Hamlin' com 3 anos de idade cultivadas em solo arenoso na região central da Flórida. Koo e Harrison $(1965,1969)$, relataram anual valor de ETc de $1170 \mathrm{~mm}$ para plantas adultas de citrus no mesmo solo.

No período de estabelecimento da cultura, em condições de clima árido e semiárido uma recomendação de caráter geral é aplicar 10, 15, 25, 45 e $65 \mathrm{~L} /$ planta/dia durante o verão do primeiro ao quinto ano, respectivamente e do sexto ano em diante sugere-se aplicar $100 \mathrm{~L} /$ planta/dia. Essas variações no consumo de água de um pomar de laranja ocorrem dependendo da demanda de água pela atmosfera, que aumenta com a radiação solar, temperatura e com a velocidade do vento e diminui com o aumento da umidade relativa, e das variações no sistema de plantio (espaçamento) e porta-enxerto utilizado, o que afeta o tamanho e o vigor das plantas proporcionando uma maior ou menor superfície transpirante (COELHO et al., 2004).

\subsubsection{Clima}

Média anual de ETc para citrus na Flórida varia de 820 a 920 mm (ROGERS; BARTHOLIC, 1976; FARES; ALVA, 1999) para plantas jovens ( $<5$ anos), e de 1170 a 1280 mm (KOO, 1978, ROGERS; BARTHOLIC, 1976) para planta adulta (10 anos ou mais). Valores anuais de ETc relatados para plantas adultas cultivadas no Baixo Rio Grande Vally do Texas são similares aos relatados para Flórida, os quais variaram de 1044 a 1232 mm (WIEGAND et al., 1982). Hoffman et al. (1982) reportaram valores anuais de ETc para plantas cítricas bem irrigada cultivadas na reigão semi árida do 
Arizona de $1470 \mathrm{~mm}$. Menores taxas de ETc para Flórida (clima umido) quando comparado com Arizona (clima semi-árido) tem sido atribuido a menor demanda evaporativa (ROGERS et al., 1983, FARES; ALVA, 1999).

A transpiração de árvores de lima ácida 'Tahiti' estimada pelo Método do Balanço de Calor no caule nas condições de Piracicaba, SP, foi em média de $90 \mathrm{~L}_{\text {planta }}{ }^{-1}$ dia $^{-1}$ no verão e $36 \mathrm{~L}_{\text {planta }}{ }^{-1}$ dia $^{-1}$ no inverno, isso para plantas com área foliar total de $90 \mathrm{~m}^{2}$ (MARIN et al., 2002). Em condições de clima subtropical, o consumo anual de água da laranja Valência varia, conforme o ano, de 11.733 a $16.030 \mathrm{~m}^{3}$ /árvore sendo o consumo médio de plantas adultas e sadias de 50 a $90 \mathrm{~L}_{\text {planta }}{ }^{-1}$ dia $^{-1}$ no inverno e de 90 a $150 \mathrm{~L}$ planta $^{-1}$ dia $^{-1}$ na estação seca da primavera (COELHO et al., 2004).

\subsubsection{Conteúdo de água no solo}

Rogers et al. (1983) relataram que o crescimento e a produtividae das plantas cítricas foram maior durante um período de 3 anos para tratamentos mantidos em maior conteúdo de água no solo. Durante o mesmo período, a média anual de ETc foi de 900 e $1210 \mathrm{~mm}$ para o mais baixo e mais alto conteúdo de água no solo, respectivamente. Hoffman et al. (1982) relataram valores anuais de ETc 200 a $500 \mathrm{~mm}$ maior quando comparado aos valores encontrados por Erie et al. (1965) no Arizona. Os menores valores de ETc relatados por Erie et al. (1965) foram atribuido a baixa frequência de irrigação resultando em superfície de solo seca, incrementando a resistência para difusão da água para a atmosfera. Smajstrla et al. (1986) relataram uma redução no crecimento e ETc de planta, com incremento de disponibilidade de água no solo para laranja 'Valencia' de 2 anos de idade cultivada em lisímetro de drenagem. Os diferentes conteúdos de água no solo (depleções) utilizados neste estudo para o manejo das irrigações foram 28\%, 47\% e 58\%. Foi concluído que ocorreu estress hídrico no mais alto valor de depleção de água no solo devido a redução da capacidade do solo de transportar água para as raízes (redução na condutividade hidráulica do solo). Fares e Alva (1999) calcularam diariamente ETc para plantas de laranja 'Hamlin' em solo 
arenoso na Flórida Central. Relataram que valores diários de ETc decresceram com o tempo após chuva ou irrigação.

No Estado de São Paulo o consumo de água aproxima-se de $3 \mathrm{~mm} \mathrm{dia}{ }^{-1} \mathrm{em}$ pomares irrigados e de 1,5 $\mathrm{mm} \mathrm{dia}^{-1}$ nos não irrigados (COELHO et al., 2004).

\subsubsection{Cobertura do solo}

Castel et al. (1987) estimaram a evaporação de água na superfície do solo, usando lisímetros de pesagem. A evaporação média estimada foi $0,78 \mathrm{~mm}$ ou $18 \%$ maior do que ETo de 4,25 mm. Castel e Buj (1992) relataram que a percentagem de área sombreada por uma planta jovem de Clementina aumentou de 10 a $25 \%$ durante um período de 4 anos. A ETc aumentou 33\% durante o mesmo período. A este aumento foi atribuido o aumento do uso da água pela árvore e redução da superfície evaporativa.

\subsubsection{Controle do mato}

Smajstrla et al. (1986) usaram lisímetro de drenagem para determinar o efeito das plantas daninhas no crescimento e na ETc de plantas de laranja 'Valência' de 2 anos de idade. Coberturas com gramas foram instaladas no período das chuvas para cobrir completamente o solo. O lisímetro com solo (sem grama) teve o mais baixo valor mensal de ETc. Medidas anuais de ETc variaram entre 1331 a $900 \mathrm{~mm}$ para lisímetros cobertos com grama e 912 a $441 \mathrm{~mm}$ para os lisímetros com solo sem grama. A ETc anual total foi 46 a 105\% maior devido a cobertura com grama. Estes resultados foram similares aos relatados por Stewart et al. (1969). O quais estimaram a evaporação anual de água em solo sem cobertura e com 2/3 de cobertura. As ETc médias foram 68 e $92 \%$ da cobertura total, respectivamente. Tucker et al. (1997) relataram redução na ETc de pomar adulto de citros, quando as entrelinhas não foram irrigadas e as plantas daninhas controladas com contole químico. 


\subsection{Coeficiente de Cultivo (Kc)}

Uma estimativa da ETc para uma específica cultura pode ser calculado multiplicando a ETo pelo um empírico coeficente de cultivo $(K c)$. Este coeficiente é específico para cultura, estágio de cresciemento, e condições de cultivo. Resultando em estimativas de uso de água de uma cultura sob condições climáticas locais ou regionais.

De acordo com Doorembos e Pruitt (1977) e Allen et al. (1998) valores de coeficiente de cultivo $(K c)$ para pomares cítricos com plantas jovens cobrindo $20 \%$ do terreno variam de 0,45 a 0,55 (plantas em terreno limpo) e 0,85 a 0,90 (plantas em terreno com mato); plantas jovens cobrindo $50 \%$ do terreno variam de 0,55 a 0,65 (plantas em terreno limpo) e 0,75 a 0,85 (plantas em terreno com mato); 0,60 a 0,75 (plantas em terreno limpo) e 0,75 a 0,85 (plantas em terreno com mato).

Rogers et al. (1983) relataram medidas mensais da relação entre ETc medido e ETo calculado usando a média de 4 métodos de estimativa (Penman, Blaney-Criddle, Jensen-Haise, e Tanque Classe A). Os resultados de $K c$ variaram de 0,90 em Janeiro (inverno) a 1,11 em Junho (verão).

Os valores de $K c$ relatados por Doorenbos e Puitt (1977) após ajuste para condições umidas variam de 0,9 de Março até Dezembro a 0,95 em Janeiro e Fevereiro. Castel et al. (1987) estimaram $K c$ mensal para pomar de laranja 'Navel' adulto irrigado por gotejamento cultivado em Valência, Espanha. Os valores de $K c$ divulgados por eles foram calculados em função da média diária de ETc estimada por balanço hídrico onde o armazenamento de água foi determinado com o auxílio de sonda de neutrons. Valores variaram de uma média de 0,71 de Janeiro até Julho a 0,9 de Agosto até Dezembro. Castel e Buj (1992) sugeriram que estes valores diferiram dos relatados para Flórida devido ao menor demanda evaporativa da Costa Leste da Espanha, a qual tem uma média annual de ETo de 1116 mm comparado com 1400 mm na Flórida.

Valores de Kc de pomares de laranja 'Hamlin' de 3 anos de idade cultivadas em solo arenoso na região central da Flórida variou de aproximadamente 1,05 de Novembro até Março a 0,85 de Maio a Agosto (FARES; ALVA, 1999). Boman (1994) calculou valores de $K c$ para pomar de laranja 'Valência' de 5 anos de idade cultivada em área 
com água mantida a $0,6,0,75$, ou $0,9 \mathrm{~m}$ da superfície do solo. Os valores de $K c$ calculados variaram de um valor mínimo de 0,6 de Dezembro a Fevereiro (inverno) e máximo de 1,1 em Junho e Julho (verão). Martin et al. (1997) estimaram médias diárias de ETc em um pomar de Grapefruit 'Redblush' de 7 anos de idade no Arizona, com conteúdo de água no solo coletado de 1 a 2 semanas de intervalo. Valores mensais de $K c$ foram caculados pela relação da média diária de ETo estimada para o mesmo período. Os resultados de $K c$ variaram de um valor mais baixo de 0,55 a 0,66 em Dezembro e Janeiro a um valor mais alto de 1,1 a 1,2 em Julho.

A recomendação de Vieira e Ribeiro (1993) é de $K c$ igual a 0,8 para plantas adultas de lima ácida 'Tahiti'. Para laranja Pêra enxertada em limão Cravo com 4 anos e com espaçamento de 7x4 m, Bertonha (1997) recomenda o $K c$ de 0,75. Enquanto que, para laranjas 'Baianinha' e 'Hamlin' em porta-enxertos laranja Caipira e limão Cravo o $K c$ é 1,0 no outono-inverno e em condições de suprimento hídrico adequado. De acordo com Iaffe (1996) esse valor diminui até próximo de zero em condições de estiagem prolongada, e após esse período não há pronta recuperação do $K c$ com suprimento hídrico adequado.

\subsection{Manejo da Irrigação}

Há inúmeros trabalhos na literatura que avaliaram a resposta da planta cítrica em função do manejo da irrigação pelo monitoramento do solo e/ou clima. O manejo da irrigação envolve a tomada de decisão sobre quando irrigar e quanto de água aplicar. Para auxiliar na tomada de decisão mais apropriada, diferentes métodos foram desenvolvidos. Pode-se, portanto, programar a irrigação de um pomar usando-se um método ou uma combinação de dois ou mais métodos. Entre os métodos de manejo da irrigação disponíveis, os mais usados baseiam-se em: (1) turno de rega calculado; (2) medidas do teor ou estado energético da água no solo; (3) balanço hídrico diário na zona radicular e (4) instrumentos de evaporação.

O turno de rega ou freqüência de irrigação TR (dias) é dado pela razão entre a lâmina líquida de irrigação (LL) e a ETc. Onde LL é a lâmina (mm) a ser reposta a cada 
irrigação. $\mathrm{O}$ seu valor pode ser obtido pela diferença entre o teor de umidade do solo $\left(\mathrm{cm}^{3} . \mathrm{cm}^{-3}\right)$ na capacidade de campo e no ponto de murcha permanente, multiplicado pela profundidade efetiva do sistema $(z)$ radicular $(\mathrm{mm})$ e pelo fator de variação máxima permissível (f) da disponibilidade de água no solo (decimal) sem causar redução na produtividade da cultura.

Para plantas cítricas este fator de disponibilidade $(f)$ de água no solo varia em função da combinação copa-cavalo, desenvolvimento da planta, do estádio fenológico e da demanda hídrica atmosférica local. Segundo Koo (1963) para plantas cítricas de uma forma geral esse valor varia entre 0,33 a 0,66. Shavalhevet e Levy (1990) esse valor varia entre 0,30 a 0,40. Para Marler e Davies (1990) o valor está entre 0,30 e 0,45, enquanto Coelho et al. (2004) recomenda valores de $f$ de 0,30 a 0,35 durante o período crítico entre a brotação e até que o fruto atinja $2,5 \mathrm{~cm}$ de diâmetro. No restante do ano esse valor pode subir para 0,50 a 0,60 , permitindo maior $T R$ ou menor freqüência na aplicação de água. O valor máximo de $f$ deve ser em torno de 0,50 e valor máximo de $z$ deve variar de 1,2 a 1,5 m. Para fins de manejo, a escolha do valor apropriado de $z$ deve ser cuidadosa, tendo em vista a proporcionalidade entre $L L$ e $z$.

Marler e Davies (1990), manejando a irrigação com base no Turno de rega, compararam o crescimento de plantas de 'Hamlin' com 1 ano de idade usando $f$ de 0,20; 0,45 e 0,65 a 0,3 m de profundidade, através de medidas de umidade com uma sonda de nêutrons. $\mathrm{O}$ crescimento das raízes e da copa das plantas foi o mesmo quando utilizado $f$ de 0,20 e 0,45 embora as plantas com 0,45 receberam menos irrigações e menos água do que a 0,20 . As plantas irrigadas $\operatorname{com} f$ de 0,65 tiveram significativamente menos raízes e crescimento de ramos do que nos outros tratamentos.

Em um trabalho posterior, com a mesma variedade, porém enxertadas em citromeleiro 'Swingle', Davies e Zalman (2000) verificaram que não houve diferenças significativas quanto ao diâmetro do tronco em plantas manejadas com alta freqüência de irrigação (três dias) comparativamente as que foram irrigadas usando $f$ de 0,30 no primeiro e segundo fluxo de crescimento e $f$ de 0,50 no restante do ciclo.

Tignor et al. (1998) irrigaram plantas de 'Hamlin' com 1 ano de idade baseado no turno de rega (conteúdo de água disponível) em vários fluxos de crescimento. Eles não 
encontraram efeito significativo no crescimento do tronco, mas os altos níveis de esgotamento do solo atrasaram o desenvolvimento do segundo fluxo.

O manejo da irrigação também pode ser realizado por medidas do teor ou estado energético da água no solo. Nesse caso, o momento da irrigação é determinado pelo estado atual da água do solo, por meio de sensores, quer para determinação do conteúdo de umidade quer para determinação da tensão de água do solo.

O conteúdo de umidade do solo, para definição do momento de irrigar, pode ser obtido por métodos diretos, tal como o gravimétrico, e indiretos. A TDR (Reflectometria no Domínio do Tempo), a sonda de capacitância e a sonda de nêutrons permitem a obtenção direta do teor de água no solo, apesar de precisarem de calibração prévia, ou seja, estimam a umidade. Por outro lado, os blocos de resistência elétrica e o tensiômetro permitem a obtenção indireta da umidade do solo, isto é, fornecem a tensão de água no solo, do qual se estima a umidade pela curva de retenção de água do solo. Conhecendose a umidade atual do solo $(\theta a)$ por meio de qualquer um dos métodos acima, e comparando-a com a umidade do solo crítica $(\theta c)$ para a cultura, decide-se irrigar quando $\theta a \geq \theta c$. Conhecendo-se $\theta a$ então $L L$ pode ser dada pela diferença entre o teor de umidade do solo $\left(\mathrm{cm}^{3} . \mathrm{cm}^{-3}\right)$ na capacidade de campo e no ponto atual, multiplicado pela profundidade efetiva do sistema radicular $(\mathrm{mm})$.

Algumas pesquisas têm mostrado que níveis de umidade do solo na faixa de $66 \%$ da água disponível são adequados para produtividades ótimas para as culturas cítricas (COELHO et al., 2004).

Existe uma relação direta entre umidade e potenciais da água no solo, sendo que o potencial matricial, para irrigação, é o principal componente do potencial total, representando o estado energético em que a água está retida no solo. Quanto mais seco o solo menor (mais negativos) serão os potenciais.

Os potenciais críticos para cultura irão variar em função do método de irrigação utilizado e do tipo de solo. Para irrigação localizada, como existe alta freqüência e manutenção de elevados níveis de umidade na zona de irrigação, os potenciais são utilizados basicamente como referência para checar se a umidade está adequada na zona de extração de água pelo sistema radicular e também se está havendo perda de água 
abaixo dessa zona. No caso da irrigação por aspersão, os potenciais são, também, usados na tomada decisão sobre o momento de irrigar, pois nesse método as freqüências de irrigação não são elevadas comparadas às adotadas em gotejamento e microaspersão.

De maneira geral os potenciais matriciais para as culturas cítricas devem ser mantidos entre -15 e $-30 \mathrm{kPa}$ a $0,30 \mathrm{~m}$ de profundidade, apesar de existir recomendações para manutenção de valores entre -30 e $-45 \mathrm{kPa}$. De maneira geral os valores adotados em irrigação localizada podem ser maiores que os adotados em aspersão (COELHO et al., 2004).

$\mathrm{Na}$ literatura encontramos vários trabalhos citando níveis de tensão crítica para citros, como recomendação na determinação do momento das irrigações, como: -0,01 a 0,02 MPa (Taylor, 1965), -0,06 a -0,07 MPa (HILGEMAN, 1977), -0,09 $\mathrm{MPa}$ (COHEN, 1991), -0,01 a -0,035 MPa (BIELORAI et al.1984), -0,02 a -0,03 MPa (POGUE; POOLEY 1985), -0,05 a -0,07 MPa (SHALHEVET; LEVY, 1990).

Smajstrla et al. (1985) avaliaram o crescimento de plantas de 'Valência' em formação na Flórida, irrigadas em função de diferentes tensões de água no solo. Verificaram que o crescimento do primeiro ano no campo foi maior a $20 \mathrm{kPa}$ de tensão no solo comparativamente com 10 ou $40 \mathrm{kPa}$, mostrando que o crescimento ótimo da planta está relacionado com a manutenção de um nível adequando de umidade no solo, mostrando que o excesso e o déficit de umidade retardaram o crescimento da planta.

González-Altozano e Castel (2000), na Espanha, constataram que tensões no solo de $45 \mathrm{kPa}$, no perfil de $0,4 \mathrm{~m}$ de produndidade, praticamente cessaram o alongamento dos ramos de tangerina 'Clementina' na fase de florescimento e pegamento dos frutos. Enquanto que, Paramasivam et al. (2000) relatam que, na Flórida, tem sido recomendado valores de tensão de 10 a $15 \mathrm{kPa}$ durante os meses de Janeiro a Maio (período seco) e Julho a Dezembro (período chuvoso), respectivamente.

Um ponto importante a ser observado é quanto à localização dos sensores no perfil do solo. Como regra geral, deve-se instalar os sensores no centro de atividade do sistema radicular, ou numa região do sistema radicular representativa do cenário geral de extração de água. 
Sensores que monitoram níveis de tensão da água no solo devem ser instalados na metade da profundidade efetiva das raízes para indicar o momento de irrigação e também na profundidade efetiva para controle da frente de molhamento (PIRES, 1992).

No caso de plantas cítricas, $80 \%$ da extração de água ocorre entre 0 e $60 \mathrm{~cm}$ de profundidade no perfil do solo. Santos (2002) em estudos sobre a absorção de água pelas raízes de lima ácida 'Tahiti', sob microaspersão em condições semi-áridas mostrou que, no sentido longitudinal à fileira de plantas a mesma ocorreu a distâncias horizontais da planta, inferiores a 1,5 $\mathrm{m}$ e profundidade até $0,5 \mathrm{~m}$. Para distâncias horizontais à planta, inferiores a 0,5 m, a absorção de água pelas raízes foi até a profundidade de $1,1 \mathrm{~m}$. No perfil ortogonal à fileira de plantas, a extração de água pelas raízes se localizou na região de profundidade de 0 a $0,5 \mathrm{~m}$ e na distância horizontal da planta de 0 a 1,2 m

Para fins de manejo da irrigação de um pomar de plantas cítricas, o balanço entre evapotranspiração e chuvas pode ser usado.

A evapotranspiração da cultura é a soma do que o pomar perde na forma de evaporação da água no solo e transpiração das plantas. Portanto, de maneira simplista, a lâmina de água aplicada no pomar é baseada no balanço entre a evapotranspiração da cultura ( $\mathrm{mm} / \mathrm{dia})$ e os totais de chuvas $(\mathrm{mm} / \mathrm{dia})$ para um período de secamento do solo entre duas irrigações. Na prática, a evapotranspiração da cultura $(E T c)$ é determinada indiretamente por metodologias com base nos elementos meteorológicos importantes para esse processo (temperatura, umidade relativa, radiação solar e velocidade de vento).

A ETo pode ser estimada também com o uso de evaporímetros, como o conhecido Tanque Classe A, a partir da lâmina d'água evaporada no tanque e de um fator de correção denominado Coeficiente do Tanque $K p$. O $K p$ varia de acordo com a velocidade do vento, a exposição do tanque, a bordadura e a umidade relativa média do ar.

Castel e Buj (1992) compararam o crescimento de plantas de 'Clementine' na Espanha, com 1 ano de idade a duas freqüências de irrigação e a quatro diferentes taxas de aplicação. A quantidade de água aplicada foi baseada de $40 \%$ a $130 \%$ da evaporação do Tanque Classe A. Quanto à freqüência de irrigação, uma versus duas vezes por semana, não houve efeito significativo no crescimento, enquanto que a taxa de irrigação 
afetou o crescimento. O diâmetro do tronco e o índice de área foliar foram significativamente menores na menor taxa (40\%). O crescimento ótimo para os dois primeiros anos ocorreu com a aplicação da água a 70\% do tanque e uma vez por semana. Durante o terceiro ano do estudo, a taxa de $130 \%$ proporcionou maior diâmetro do tronco e maior volume da copa.

Castel (1993) aplicou quatro níveis de irrigação por gotejamento em plantas jovens de 'Nules Clementine' baseado na evaporação de 30 a 200\% do tanque Classe 'A'. Mostrando uma relação linear do aumento no diâmetro do tronco com o aumento na taxa de aplicação de água, ainda que os dados indicavam que o tamanho inicial teve mais efeito sobre o tamanho final do que a taxa de aplicação.

Castel (1994) estudando a resposta de plantas jovens de tangerina 'Clementina' irrigada por gotejamento a 50, 80, 110 e 140\% da evapotranspiração da cultura (ETc) determinada via lisímetro de pesagem, verificou que a irrigação a $50 \%$ produziu alto estresse hídrico, reduziu o crescimento da planta e diminuiu o número de frutos por planta. O crescimento ótimo foi obtido com irrigação de $110 \%$ da ETc.

Swietlik (1992) compararam irrigações baseadas no Tanque Classe A, tensão do solo e conteúdo de água disponível e verificaram que e a quantidade de água aplicada foi maior quando baseada no Tanque Classe A do que por tensiômetros e na maioria dos anos o crescimento dos ramos foi similar.

\subsection{Resposta das culturas cítricas a irrigação}

Dentre as técnicas agrícolas de importância para a citricultura, o manejo da água é uma prática que pode influenciar diretamente na produtividade dessa cultura. A alternância de período seco durante o inverno e chuvoso no início da primavera induz o florescimento das plantas cítricas. No entanto, a ocorrência de déficit hídrico, durante a floração e início da frutificação, provoca queda de flores e de frutos, reduzindo sua produtividade. 
Dependendo da região de cultivo as necessidades de irrigação serão maiores ou menores. É esperado, portanto, que as necessidades e respostas à irrigação sejam maiores em regiões semi-áridas, quando a viabilidade do pomar só é possível com a prática da irrigação; menores em regiões sub-úmidas onde a prática de irrigação será realizada para complementar a deficiência hídrica em períodos específicos do ano; e inviáveis economicamente em regiões úmidas, com pequena ou sem apresentar deficiência hídrica ao longo de um ano.

Um experimento realizado em um pomar de laranja 'Pêra' com quatro anos de idade no município de Inhambupe/BA, região sub-úmida do litoral norte da Bahia foi avaliado a aplicação de cinco níveis de irrigação correspondentes às lâminas anuais de $174 \mathrm{~mm}, 261 \mathrm{~mm}, 347 \mathrm{~mm}, 487 \mathrm{~mm}$ e $608 \mathrm{~mm}$ usando por microaspersão. A deficiência hídrica no solo acumulada chegou a $521 \mathrm{~mm}$. Nestas condições, a curva de resposta mostrou que a produtividade da laranja aos níveis de irrigação teve um comportamento quadrático, com um máximo de produtividade de $35,1 \mathrm{t}$ para a lâmina de irrigação de $442 \mathrm{~mm} / \mathrm{ano}$. O número de frutos por planta seguiu a mesma tendência da produtividade, com um máximo de 351 frutos por planta para a lâmina de $462 \mathrm{~mm} / \mathrm{ano}$. A produtividade obtida foi altamente satisfatória, levando em conta que o rendimento médio da citricultura baiana situa-se abaixo de 200 frutos por planta ano. Neste estudo, verificou-se que a taxa de aumento da produtividade foi mais alta até a faixa de 250-350 $\mathrm{mm} / \mathrm{ano}$, reduzindo-se em seguida, com menores incrementos de produtividade por milímetro aplicado, o que mostra que para tais condições a aplicação de $250 \mathrm{~mm}$ é suficiente para uma aumento relevante na produtividade (COELHO et al., 2004).

Bertonha et al. (2004), no município de Maringá -PR, em região subtropical úmida, avaliando níveis de irrigação $(10,15,20$ e $25 \mathrm{~mm})$ complementar em laranjeira 'Pêra, irrigadas por gotejamento, encontraram que a produção, produtividade, peso médio dos frutos e a quantidade de sólido solúvel produzido por árvore apresentaram uma relação quadrática em função das lâminas aplicadas.

Em um estudo realizado em Pratânia-SP, em uma área comercial de laranja Valência irrigada por microaspersão, obteve resultados que mostraram que a irrigação proporcionou um aumento de $11,3 \%$ na produtividade (DUENHAS et al., 2000). 
Segundo Vieira (1988), mediante adequado suprimento de água às plantas cítricas, a irrigação pode aumentar o pegamento de flores e frutos e melhorar a qualidade de frutos.

Parsons e Morgan (2004) relatam que a uso da irrigação é essencial no sistema de produção de citrus na Flórida. Estudos mostram que a irrigação proporciona um aumento de produção de 39 a 64\% em relação a pomares sem irrigação.

\subsection{Distribuição das raízes e Bulbo molhado}

Diferentes métodos de irrigação e manejo tem mostrado influência na distribuição e/ou concentração de raízes. Em um estudo na Califórnia com árvores recebendo diferentes níveis de irrigação, a produtividade não correlacionou com densidade de raízes (CAHOON et al., 1964), pois árvores em baixas taxas de irrigação diminuiu a produtividade enquanto manteve quantidades similares de raízes quando comparado a plantas irrigadas com altos níveis de irrigação. Concluiram que o conteúdo de água no solo foi o fator mais importante a influenciar a distribuição do sistema radicular do citrus.

Em um estudo na Flórida, densidades de raízes, com base no peso seco, foram estimadas sob a copa, na linha de gotejamento, e na entre linha de plantas de laranja 'Hamlin' enxetada em citrumelo 'Swingle' e citrange 'Carrizo' até a profundidade de $180 \mathrm{~cm}$ (MENOCAL-BARBERENA, 2000). Plantas que receberam irrigação em uma taxa de $400 \mathrm{~mm} \mathrm{ano}^{-1}$ teve significantemente maior densidade de raízes do que plantas que receberam $2500 \mathrm{~mm}$ ano $^{-1}$. As diferenças foram na ordem de 1,3 a 2,3 vezes maior para o tratamento irrigado com $400 \mathrm{~mm}$ noo $^{-1} \mathrm{em}$ todas as profundidades.

Vários autores relatam, que um dos principais problemas da irrigação por gotejamento em pomares, consiste em decidir o número de gotejadores por planta ou por fileira de plantas, pois isso irá determinar o preço do sistema por unidade de área, e em muitos casos, a própria produção e rentabilidade. Somente conhecendo as dimensões do bulbo molhado formado no solo em função da emissão de água, assim como o conhecimento das dimensões do sistema radicular da cultura a ser irrigada, pode-se definir o número de emissores por planta. 
Em testes realizados em laboratório e no campo, Bresler et al. (1971) chegaram à conclusão de que um aumento na taxa de vazão por gotejador resulta um aumento na extensão horizontal do bulbo e um decréscimo na extensão vertical, isto para um mesmo tipo de solo e um mesmo volume de água aplicado. Isso foi confirmado por Vermeiren e Jobling (1997) afirmando que para um mesmo tempo de irrigação, quanto maior for a vazão do emissor, maior é a extensão horizontal do bulbo.

Segundo Parsons e Morgan (2004), a definição do tamanho do bulbo molhado é um dos aspectos importantes para maximizar a produção de citrus cultivado em solos arenosos na Flórida. As raízes de árvores adultas estendem-se horizontalmente por toda área do solo por causa das chuvas abundantes que ocorrem naturalmente. Diversos estudos mostraram que a produtividade aumenta diretamente com o aumento do bulbo molhado na região do sistema radicular. A vazão e o espaçamento dos gotejadores no tubo, deveria ser especificados de acordo com textura do solo e o espaçamento entre plantas, pois a frente de molhamento de um gotejador não se expande muito horizontalmente em solos arenosos. Em plantas jovens é recomendado um ou dois gotejadores por planta. Enquanto que em plantas adultas o bulbo molhado deve ser incrementado. Quando a opção for a utilização de microaspersor ou spray jet, estes possuem a vantagem de proporcionar maior bulbo molhado em relação ao gotejador. A pesquisa tem mostrado que a utilização de um microaspersor por planta tem apresentado maior produção em relação a dois ou quatro gotejadores por planta.

Souza et al. (2003) avaliaram a influência do tamanho do bulbo molhado (porcentagem de área molhada de 15, 31 e 46\%) sobre a produção de lima ácida 'Tahiti'. Constataram que a porcentagem de área molhada não afetou significativamente a produção. Porém o valor absoluto da produção foi $27 \%$ maior no tratamento com maior bulbo molhado.

Quanto ao desenvolvimento do sistema radicular, Moreira (1983) afirma que embora as condições de solo, cultivo e espécie possam modificar a arquitetura radicular, seus estudos verificaram que, para laranjeiras 'Baianinha' e 'Pêra', cerca de 46\% das radicelas encontram-se nos primeiros $15 \mathrm{~cm}$ de profundidade, $45 \%$ estão até $30 \mathrm{~cm}$ e 
$73 \%$ até $60 \mathrm{~cm}$. Horizontalmente, as raízes desenvolvem-se até 4,2 $\mathrm{m}$ de distância a partir do tronco, com pequena redução entre 3,5 e 4,2 m.

Além da baixa condutividade das raízes, que varia em função da temperatura e do porta-enxerto utilizado, o sistema radicular pode ser considerado superficial. Rodriguez et al., (1978) fizeram amostragens de raízes aos 3, 6, 12, 24 e 36 meses de idade de portaenxertos: Limoeiro Cravo, laranja Caipira e Poncirus trifoliata, e verificaram que 80 a $90 \%$ das raízes se encontravam até $0,5 \mathrm{~m}$ de profundidade. Enquanto que para plantas adultas, Montenegro (1960) verificou que 90\% das raízes atingem até 0,6 $\mathrm{m}$ de profundidade para árvores de 10 anos e até $0,9 \mathrm{~m}$ em plantas de 23 anos. Moreira (1983) em um estudo de sistema radicular em plantas de 7 anos, constatou que $60 \%$ das raízes se encontram a $0,3 \mathrm{~m}$ de profundidade, e $73 \%$ das raízes até 0,6 m. Pires (1992), para fins de irrigação, recomenda considerar $0,6 \mathrm{~m}$ como profundidade efetiva das raízes em pomares em produção.

No entanto, como ressalva deve-se observar que o domínio e a distribuição do sistema radicular das culturas cítricas, da mesma forma que de outras culturas, depende das características físicas do solo, em especial da textura e estrutura, dos fatores genéticos, do teor de água do solo, que atua na resistência do solo à penetração das raízes (GREGORY, 1987; KLEPPER, 1987).

Coelho et al. (2002) estudando o comportamento do sistema radicular de laranja 'Pera' sob irrigação por microaspersão e sequeiro sob solo arenoso, encontraram que a distribuição das raízes em profundidade mostrou-se mais uniforme na microaspersão do que nas áreas não irrigadas $(0-0,7 \mathrm{~m})$ que concentrou a maior parte das raízes na camada de $0-0,3 \mathrm{~m}$, pois a irrigação melhorou a umidade do solo no perfil, em especial no período seco, contribuindo para uma maior expansão em profundidade e em distância radial do tronco do que sob condições não-irrigadas.

Mattos Jr. et al. (2003) avaliando a distribuição do sistema radicular de laranja 'Hamlin' enxertada em citrumelo 'Swingle' de 6 anos de idade, encontraram a densidade

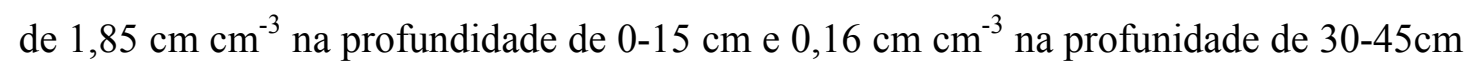
distante $50 \mathrm{~cm}$ do tronco. A $150 \mathrm{~cm}$ do tronco, a dendidade de raízes foi $48 \%$ menor que a $50 \mathrm{~cm}$ distante do tronco na camada de $15 \mathrm{~cm}$. 
Santos et al. (2002) avaliando a distribuição do sistema radicular da lima ácida 'Tahiti' enxertada com citrumelo 'Swingle' sob microaspersão no semi-árido Baiano e em solo de textura média, encontraram que a profundidade efetiva das raízes foi de $0,25 \mathrm{~m}$, com distância efetiva de 1,0 m, sugerindo serem estas as medidas mais adequadas para a instalação de sensores para monitoramento d'água do solo, visando o manejo da irrigação.

As maiores produtividades em citros nos cerrados, em áreas de pesquisa do Centro Nacional de Pesquisa Agropecuária dos Cerrados (CPAC), foram obtidas sob o sistema de gotejamento a cada metro, aplicando 120 litros de água por planta a cada 4 dias (COELHO et al., 1994).

\section{Referências}

ALLEN, R.G.; PEREIRA, L.S.; RAES, D.; SMITH, M. Crop evapotranspiration: guindelines for computing crop water requirements. Rome: FAO, 1998. 300 p. (Guideline, 56)

ALVES JUNIOR, J.; SILVA, C.R.; SILVA, T. J.A.; FOLEGATTI, M.V. Consumo de água das plantas cítricas. Citricultura Atual, Cordeirópolis, v. 1, n. 39, p. 14-15, 2004.

BERTONHA, A. Funções de resposta da laranja à aplicação de água e nitrogênio. 1997. 62 p. Tese (Doutorado em Irrigação e Drenagem) - Escola Superior de Agricultura "Luiz de Queiroz", Universidade de São Paulo, Piracicaba, 1997.

BIELORAI, H. The effect of partial wetting of the root zone on yield and water use efficiently in a drip and sprinkler-irrigated mature grapefruit grove. Irrigation Science, Berlin, v. 3, n. 2, p. 89-100, 1982.

BOMAN, B.J. Evapotranspiration from young Florida flatwoods citrus trees. Journal of Irrigation and Drainage Engineering, New York, v. 120, n. 1, p. 81-88, 1994.

BRESLER, E. Infiltration from a trickle source. II Experimental data and theoretical predictions. Soil Science Society of America Proceeding, Madison, v. 35, n. 5, p. 683689, 1971. 
BRITO, A. Avança a irrigação na citricultura paulista. Gazeta Mercantil, Finanças \& Mercados, Campinas, 16 jun. 2004.

CAHOON, G.A.; STOLZY, L.H.; GARBER, M.J.; MORTON. E.S. Influence of nitrogen and water on the root density of mature Washington Navel orange trees. Journal of the American Society for Horticultural Science, Geneva, v. 85, p. 224$231,1964$.

CASTEL, J.R. Response of young Clementine citrus trees to drip irrigation. Acta Horticulturae, Leuven, n. 335, p. 313-324. 1993.

CASTEL, J.R. Response of Young clementine citrus trees to drip irrigation. I. Irrigation amount and number of drippers. Journal of Horticultural Science, Kent, v. 69, n. 3, p. 481-489, 1994.

CASTEL, J.R.; BUJ, A. Growth and evapotranspiration of young, drip-irrigated Clementine trees. Proceedings of the International Society of Citriculture, Acireale, v. 2, p. 651-656, 1992.

CASTEL, J.R.; BAUTISTA, I.; RAMOS C.; CRUZ, G. Evapotranspiration and irrigation efficiency of mature orange orchards in 'Valencia' (Spain). Irrigation Drainage Systems, Netherlands, v. 3, p. 205-217, 1987.

COELHO, E.F.; MAGALHAES, A.F.J.; COELHO FILHO, M.A. Irrigação e fertirrigação em citros. Cruz das Almas: Embrapa, CNPMF, 2004. 16 p. (Embrapa. CNPMF. Circular Técnica, 72.). Disponível em: http://www.cnpmf.embrapa.br/publicacoes/circulares/circular 72.pdf. Acesso em: 23 mar. 2006

COELHO, E.F.; OLIVEIRA, F.C.; ARAÚJO, E.C.E.; VASCONCELOS, L.F.L. Distribuição de raízes de laranja 'Pera' sob sequeiro e irrigação por microaspersão em solo arenoso. Pesquisa Agropecuária Brasileira, Brasília, v. 37, n. 5, p. 603-611, 2002.

COELHO, Y.S. Lima ácida 'Tahiti'. Aspectos da produção. Brasília: EMBRAPA, SPI, 1993. 35 p. (Série Didática FRUPEX, 1).

COELHO, Y.S.; SOBRINHO, A.P.C.; MAGALHÃES, A.F.J.; PASSOS, O.S.; NASCIMENTO, A.S.; SANTOS, H.P.; SOARES FILHO, W.S. A cultura do limão 'Tahiti'. Cruz das Almas: Embrapa, CNPMF; Brasília: Embrapa, SPI, 1994. 46 p. (Embrapa. SPI. Coleção Plantar, 18).

COEN, Y. Determination of orchard water requeriment by a combinedy trunk sap flow and meteorological approach. Irrigation Science, Berlin, 12. 1991. p.93-98. 
DAVIES, F.S.; ZALMAN, G. R. Irrigation scheduling and growth of young 'Hamlin' orange trees. Proceedings of the Florida State for Horticultural Society, Washington, v. 113, p. 53-57, 2000.

DOOREMBOS, J.; KASSAM, A.H. Efeito da água no rendimento das culturas.

Tradução de H.R. Gheyi et al. Campina Grande: Universidade Federal da Paraíba; FAO, 1994. 306 p. (FAO. Irrigação e Drenagem, 33).

DOOREMBOS, J.; PRUITT, W.O.. Guidelines for predicting crop water

requirements. $2^{\text {nd }}$ ed. Rome: FAO, 1977. 179 p. (FAO. Irrigation and Drainage, 24).

DUENHAS, L.H.; VILLAS BOAS, R.L.; SOUZA, C.M.P.; RAGOZO, C.R.A. Efeitos da Irrigação e do modo de Aplicação de Fertilizantes na produção e qualidade de frutos de laranja (Citrus sinensis) variedade 'Valência'. In: CONGRESSO BRASILEIRO DE ENGENHARIA AGRÍCOLA, 29., 2000, Fortaleza. Anais ... Fortaleza: UFC; SBEA, 2000. 1 CD-ROM.

ERIE, L.J.; FRENCH, O.F.; HARRIS, K. Consumptive use of water by crops in Arizona. Tucson: University of Arizona , 1965. 44 p. (Agricultural Experiment Station Technical Bulletin, 169).

FARES, A.; ALVA, A.K. Estimation of citrus evapotranspiration by soil water mass balance. Soil Science, New Brunswick, v. 164, p. 302-310, 1999.

FIGUEIREDO, J.O. Variedades-copa de citros. In: ENCONTRO PARANAENSE DE CITRICULTURA, 1.,1986, Londrina. Anais ... Londrina: Associação dos Engenheiros Agrônomos do Paraná, 1986. p. 59-78.

FNP CONSULTORIA \& AGROINFORMATIVOS. Agrianual 2003: anuário da agricultura brasileira. São Paulo, 2003. p. 295-331.

GAYET, J.P. Cultura, volheita, beneficiamiento, transporte e comercializacização de lima ácida 'Tahiti’ (Citrus latifalia Tan.) Conchal: Frutal Agrocomportadora, 1991. $42 \mathrm{p}$.

GONZÁLEZ-ALTOZANO, P.; CASTEL, J.R. Effects of regulated déficit irrigation on 'Clementina de Nules' citrus trees growth, yield and fruit quality. Acta Horticulturae, The Hague, n.537, p. 749-758, 2000.

GREGORY, P.J. Development and growth of root systems. In: GREGORY, P.J.; LAKE, J.V.; ROSE, D.A. Root development and function. New York: Cambridge University Press, 1987. p. 146-166.

HILGEMAN, R.H. Response of citrus trees to water stress in Arizona. Proceedings of the International Society of Citriculture, Acireale, v. 1, p. 70-74, 1977. 
HOFFMAN, G.J.; OSTER, J.D.; ALVES, W.J. Evapotranspiration of mature orange trees under drip irrigation in an arid climate. Transactions of the ASAE, St. Joseph, v. 25, p. 992-996, 1982.

IAFFE, A. Avaliação da disponibilidade hídrica no solo na produção de laranjas 'Baianinha' e 'Hamlim' em Pindorama, SP. 1996. 109 p. Dissertação (Mestrado em Água e Solos) - Faculdade de Engenharia Agrícola, Universidade de Estadual de Campinas, Campinas, 1996.

INSTITUO BRASILEIRO DE GOGRAFIA E ESTATÍSTICA. Banco de dados agregados 2003. Disponível em: http://www.sidra.ibge.gov.br. Acesso em: $13 \mathrm{fev}$. 2003.

KLEPPER, B. Origin, branching and distribution of root systems. In: GREGORY, P.J.; LAKE, J.V.; ROSE, D.A. Root development and function. New York: Cambridge University Press, 1987. p. 103-123.

KOO, R.C.J. Effects of frequency of irrigation on yield of orange and grapefruit. Proceedings of the Florida State for Horticultural Society, Tallahasse, v. 74, p. 1-5, 1963.

KOO, R.C.J. Response of density planted 'Hamlin' orange on two rootstocks to low volume irrigation. Proceedings of the Florida State for Horticultural Society, Tallahasse, v.95, p.10-13, 1973

KOO, R.C.J.; HARRISON, D.S. Summary of irrigation research in Florida.

Gainesville: Florida Agricultural Extension Service, 1965. p.180-190. (Memoirs Report, 65-8).

KOO, R.C.J.; HURNER JUNIOR, G.T. Irrigation requirements of citrus grown on Lakewood fine sand. Proceedings of the Florida State for Horticultural Society, Tallahasse, v. 82, p. 69-72, 1969.

KOO, R.C.J.; SITES, J.W. Results of research and response of citrus to supplemental irrigation. Soil Science Society of America Proceedings, Madison, v. 15, p. 180-190, 1955.

LUCHETTI, M. A., MATOS Jr., D., DE NEGRI, J. D., FIGUEIREDO, J. O., Lima Ácida Tahiti: Aspectos gerais e distribuição de cultivo. In: MATOS Jr., D.; DE NEGRI, J. D.; FIGUEIREDO, J. O. (Ed.). Lima ácida Tahiti. Campinas: Instituto Agronômico, 2003. p. 1-12.

MAHRER, Y.; RYTWO, G. Modeling and measuring evapotranspiration in a daily drip irrigated cotton field. Irrigation Science, Berlin, v. 12, n. 1, p. 13-20, 1991 
MARCONDES, P.T.S. Manejo do florescimento e da produção da lima ácida 'Tahiti' com reguladores de crescimento e derriça. 1991. 120 p. Dissertação (Mestrado em Fruticultura Tropical) - Escola de Agronomia, Universidade Federal da Bahia, Cruz das Almas, 1991.

MARIN, F.R.; ANGELOCCI, L.R.; PEREIRA, A.R.; VILLA NOVA, N.A.; SENTELHAS, P.C. Balanço de energia e consumo hídrico em pomar de lima ácida 'Tahiti'. Revista Brasileira de Meteorologia, São Paulo, v. 17, n. 2, p. 219-228, 2002.

MARLER, T.E.; DAVIES, F. Microsprinkler irrigation and growth of young 'Hamlin' orange trees. Journal of American Society of Horticultural Science, Alexandria, v. 115, n.1, p. $45-51,1990$.

MARTIN, E.C.; HLA, A.K.; WALLER, P.M.; SLACK, D.C. Heat unit-based crop coefficient for grapefruit trees. Applied Engineering in Agriculture, St. Joseph, v. 13, p. 485-489, 1997.

MATTOS JUNIOR, D.; GRAETZ, D.A.; ALVA, A.K. Biomass Distribution and nitrogen-15 partitioning in citrus trees on a sandy entisol. Soil Science Society of America Journal, Madison, v . 67, p. 555-563, 2003.

MEDINA, C.L. Lima ácida Tahiti: fisiologia da produção. In: MATOS JUNIOR, D.; DE NEGRI, J.D.; FIGUEIREDO, J.O. (Ed.). Lima ácida Tahiti. Campinas: Instituto Agronômico, 2003. p.13-30.

MENOCAL-BARBERENA, O. A. Effect of rootstock on root distribution of citrus. 2000. 196p. Thesis (M.S. in Horticultural Science) Institute of Food and Agricultural Science - University of Florida, Gainesville, 2000.

MILLS, T.M.; MORGAN, KT.; PARSONS, L.R. Canopy position and leaf age affect stomatal response and water use in citrus. Journal of Crop Production, Kansas City, v. 2 , n. 2, p. $163-179,1990$

MONTENEGRO, H.W.S. Contribuição ao estudo do sistema radicular das plantas cítricas. 1960. 143 p. Tese (Cátedra) - Escola Superior de Agricultura "Luiz de Queiroz”, Universidade de São Paulo, Piracicaba, 1960.

MOREIRA, C.S. Estudo da distribuição do sistema radicular da laranjeira Pêra (Citrus sinensis Osbeck) com diferentes manejos de solo. 1983. 97 p. Tese (Livre Docência) - Escola Superior de Agricultura “Luiz de Queiroz", Universidade de São Paulo, Piracicaba,1983. 
NEVES, M.F.; LOPES, F.F.; ROSSI, R.M.; NEVES, E.M.; MARINO, R.K.; FERNANDES, W.B.; SCARE, R.F.; CAMPOS, E.M.; TEIXEIRA, L. Mapeamento e qualificação do sistema agroindustrial citrícola em 2004: Projeto do Programa de estudos dos negócios do sistema agroindustrial. Ribeirão Preto: USP, 2004. Disponível em http://www.pcarp.usp.br/acsi/anterior/808/newpage6.htm. Acesso em: 26 mar. 2006.

NIR, I.; GOREN, R.; LESHEM, B. Effects of water stress, gibberellic acid and CCC on flower differentation in 'Eureka' lemon trees. Journal of the American Society for Horticultural Science, Geneva, v. 97, n. 6, p. 774-778, 1972.

ORTOLANI, A.A.; PEDRO JÚNIOR, M.J.; ALFONSI, R.R. Agroclimatologia e o cultivo dos citros. In: RODRIGUEZ, O.; VIÉGAS, R.; POMPEU JUNIOR, J.; AMARO, A.A.(Ed.). Citricultura brasileira. 2.ed. Campinas: Fundação Cargill, 1991. v. 1, p. 153-195.

PARAMASIVAM, S.; ALVA, A.K.; FARES, A. Na evaluation of soil water status using tesniometers in a sandy soil profile under citrus production. Soil Science, Baltimores, v. 165, n. 4, p. 343-353, 2000.

PARSONS, L.R.; MORGAN, K.T. Management of microsprikler systems for Florida citrus. Florida: University of Florida, IFAS Extension, 2004. 4 p.

PASSOS, O.S.; COELHO, Y.S.; CUNHA SOBRINHO, A.P. Variedades de copa e porta-enxertos de citros. In: ENCONTRO NACIONAL DE CITRICULURA, 4., Aracajú, 1977. Anais... Aracajú: Sociedade Brasileira de Fruticultura, 1977. p. 21-41.

PIRE, R.; BAUTISTA, D.; ROJAS, E. The influence of soil moisture on the vegetative and reproduvtive growth of orange trees under tropical conditions. Acta Horticulturae, The Hague, n.335, p.527-534, 1993.

PIRES, R.C.M. Manejo da água na irrigação dos citros. Laranja, Cordeirópolis, v. 1, n.13, p. 237-260, 1992.

POGUE, W.R.; POOLEY, S.G. Tensiometric management of soil water. In:

INTERNATIONAL DRIP/TRICKLE IRRIGATION CONGRESS, 3., 1985, St. Joseph. Proceedings ... St. Joseph: ASAE, 1985. p. 761-766. (Publication, 10-85).

RODRIGUEZ, O.; INFORZATO, R.; TEÓFILO SOBRINHO, J. Estudo do sistema radicular de três porta-enxertos para citros em viveiro. Revista Brasileira de Fruticultura, Cruz das Almas, v. 1, n. 1, p. 23-30, 1978.

ROGERS, J.S.; BARTHOLIC, J.F. Estimated evapotranspiration and irrigation requirements for citrus. Soil \& Crop Science Society of Florida Proceedings, Madison, v.35, p.111-117, 1976. 
ROGERS, J.S.; ALLEN , L.H. Jr.; CALVERT, D.V. Evapotranspiration from a humidregion developing citrus grove with grass cover. Transactions of the ASAE, St. Joseph, v. 83, p. 1778-1792, 1983.

SANTOS, D.B.; COELHO, E.F.; SILVA, T.S.M. Distribuição espacial do sistema radicular do limão 'Tahiti' enxertado com citrumelo 'Swingle' sob microaspersão no semi árido Baiano. In: CONGRESSO BRASILEIRO DE ENGENHARIA AGRÍCOLA, 31., 2002, Salvador. Anais ... Jaboticabal: SBEA. 2002. 1 CD-ROM.

SENTELHAS, P.C.; COELHO FILHO, M.A.; PEREIRA, A.R. Método agrometeorológico de estimativa da época mais adequada para indução floral do limão 'Tahiti', no Estado de São Paulo. In: CONGRESSO BRASILEIRO DE AGROMETEOROLOGIA, 10., 1997, Piracicaba. Anais ... Piracicaba: SBA; ESALQ, 1997. p. 41-43.

SHALHEVET, J.; LEVY, Y. Citrus trees. In: STEWART, B.A.; NIELSEN, D.R. Irrigation of agricultural crops. Madison: American Society of Agronomy; Crop Science Society of America; Soil Science Society of America, 1990. p. 951-986.

SMAJSTRLA, A.G.; PARSONS, K.A.; VELLEDIS, G. Response of yong citrus trees to irrigation. Proceedings of the Florida State for Horticultural Society, Tallahasse, v. 98 , p. 25-28, 1985.

SMAJSTRLA, A.G.; PARSONS, L.R.; ZAZUETA, F.S.; VELLIDIS, G.; ARIBI, K. Water use and growth of young citrus trees. St. Joseph: ASAE, 1986. (ASAE. Paper, 86-2069).

SOUZA, M.J.H.; RAMOS, M.M.; SIQUEIRA, D.L.; COSTA, L.C.; LHAMAS, A.J.M.; MANTOVANI, E.C.; CECON, P.R.; SALOMÃO, L.C.C. Produção e qualidade dos frutos da limeira ácida 'Tahiti' submetida a diferentes porcentagens de área molhada. Revista Brasileira de Engenharia Agrícola e Ambiental, Campina Grande, v. 7, n. 2, p. 245-250, 2003.

STEWART, E.H.; BROWNING, J.E.; BURT, E.O. Evapotranspiration as affected by plant density and water-table depth. Transactions of the ASAE, St. Joseph, v. 12, n. 5 , p. 646-647, 1969.

SWIETLIK, D. Growth, yield and mineral nutrition of young 'Ray-Ruby' grapefruit trees under trickle or flood irrigation and various nitrogen rates. Journal of American Society of Science, Alexandria, v. 117, p. 22-27, 1992.

TAYLOR, S.A. Managing irrigation water on the farm. Transaction of the ASAE, St. Joseph, v. 8, p. 433-436, 1965. 
TIGNOR, M.E.; DAVIES, F.S.; SHERMAN, W.B. Irrigation and nutrient application frequency effects on freeze hardiness and growth of 'Hamlin' orange trees. Proceedings of the Florida State for Horticultural Society, Tallahasse, v. 111, p. 121-125, 1998.

TUCKER, D.P.; ERICKSON, C.G.; MORGAN, K.T. Middles management methods in citrus affect soil moisture retention and vegetation species. Proceedings of the Florida State for Horticultural Society, Tallahasse, v. 110, p. 39-43, 1997.

VERMEIREN, G.A.; JOBLING, G.A. Irrigação localizada. Tradução de H.R.Gheyi et al. Campina Grande: UFPB, 1997. 184 p. (Estudos FAO. Irrigação e Drenagem, 36).

VIEIRA, D.B. Fertirrigação e manejo de irrigação em citros. Laranja, Coordeirópolis, v. 2, n. 9, p. 369-376, 1988.

VIEIRA, D.B. Irrigação de citros. In: RODRIGUEZ, O.; VIEGAS, F.; POMPEU JUNIOR, J.; AMARO, A.A Citricultura brasileira. 2.ed. Campinas: Fundação Cargill, 1991. p.519-541.

VIEIRA, D.B.; RIBEIRO, T.A.P. Estudo de parâmetros básicos de irrigação do limão 'Tahiti' (Citrus limonia OSBECK) sob micro-aspersão. In: CONGRESSO BRASILEIRO DE ENGENHARIA AGRÍCOLA, 19., 1993, Ilhéus. Anais ... Ilhéus: SBEA; CEPLAC, 1993. v. 4, p. 2328-2339.

WIEGAND, C.L.; SWANSON, W.A. Citrus responses to irrigation. I. Irrigation requirements; daily, monthly, and annual evapotranspiration amounts; and water management recommendations. Journal of the Rio Grande Valley Horticultural Society, Weslaco,v. 35, p. 73-85, 1982a

WIEGAND, C.L.; SWANSON, W.A. Citrus responses to irrigation. II. Fruit yield, size, and number. Journal of the Rio Grande Valley Horticultural Society, Weslaco, v. 35, p. $87-95,1982 b$

WIEGAND, C.L.; SWANSON, W.A. Citrus responses to irrigation. III Tree trunk and canopy growth Journal of the Rio Grande Valley Horticultural Society, Weslaco, v. 35 , p. $97-107,1982$ c.

WIEGAND, C.L.; SWANSON, W.A.; CRUSE, R.R. Marrs, 'Valencia', and Ruby red juice quality as affected by irrigation plus rainfall. Journal of the Rio Grande Valley Horticultural Society, Weslaco, v. 35, p. 109-120, 1982. 


\section{DETERMINAÇÃO DO COEFICIENTE DE CULTIVO PARA LIMA ÁCIDA 'TAHITI' CULTIVADA EM PIRACICABA - SÃO PAULO USANDO LISÍMETROS}

\section{Resumo}

A expansão permanente de sistemas de irrigação localizada na citricultura paulista tem mudado o foco de manejo da irrigação, na determinação do tempo e na quantidade de água de irrigação. O requerimento de água de um pomar cítrico é difícil de estimar, pois este é influenciado por fatores de heterogenidade tais como idade, densidade de plantio e sistema de irrigação. Neste estudo, foi estimado o requerimento de água de um pomar jovem de lima ácida 'Tahiti' considerando a independente contribuicão da evaporação do solo e transpiração da cultura pela substituição do coeficente de cultivo $(K c=E T c / E T o)$ por dois coeficientes; $K e$, um coeficiente de evaporação de água do solo e $K c b$, um coeficiente de transpiração da cultura. Daí o requerimento de água de uma planta jovem de lima ácida 'Tahiti' $\left(E T_{J}\right)$ é $E T_{j}=(K e+K c b)$.ETo onde ETo é a evapotranspiração de referência. O requerimento de água de uma planta adulta $\left(E T_{m}\right)$ é $E T_{A}=K c b . E T o$, assumindo nenhuma evaporação do solo. Dois lisímetros foram utilizados, um que tinha $1,6 \mathrm{~m}$ de diâmetro e $0,7 \mathrm{~m}$ de profundidade, e o outro que tinha $2,7 \mathrm{~m}$ de diâmetro e $0,8 \mathrm{~m}$ de profundidade. O primeiro foi usado para calcular a evaporação e o segundo foi usado para transpiração. ETo foi estimada pelo modelo de Penman-Monteith (FAO-56). As medidas foram realizadas durante o período compreendido entre Agosto de 2002 e Abril de 2005 em Piracicaba, São Paulo. Os lisímetros foram instalados no centro de uma área de 1,0 ha cultivado com plantas de lima ácida 'Tahiti' enxertadas em citrumelo 'Swingle'. As plantas estavam com 1 ano de plantio, espaçadas de $7 \times 4 \mathrm{~m}$, e irrigadas por um sistema de gotejamento. Durante o período de estudo, $K c$ variou entre 0,6 a 1,22, e $K c b$ variou entre 0,4 a 1,0. Os resultados sugeriram que para plantas jovens, o volume de água por planta calculado por $K e+K c b$ é cerca de $80 \%$ maior que o volume calculado usando $K c$. Para plantas adultas, o volume de água por planta calculado usando somente $K c b$ pode ser $15 \%$ menor do que usando $K c$. A independente contribuição da evaporação e transpiração é importante para melhor entender o consumo de água de uma planta jovem de lima ácida 'Tahiti' durante a fase de crescimento, comparado a uma planta adulta.

Palavras-chave: Evapotranspiração; Citrus latifolia Tanaka; irrigação; $K c ; K c b$; irrigação localizada;

\section{Abstract}

The expansion of permanent trickle irrigation systems in Sao Paulo citrus has changed the focus of irrigation scheduling from determining irrigation timing to quantifying irrigation amounts. Water requirement of citrus orchards are difficult to estimate, since they are influenced by heterogeneous factors such as age, planting 
density and irrigation system. In this study, we estimated water requirement of young 'Tahiti' lime orchards considering the independent contributions from soil evaporation and crop transpiration by splitting the crop coefficient $(K c=E T c / E T o)$ into two separate coefficients; $K e$, a soil evaporation coefficient and $K c b$, a crop transpiration coefficient. Hence the water requirement in young 'Tahiti' lime $\left(E T_{y}\right)$ is $E T_{y}=(K e+K c b)$.ETo where $E T o$ is reference crop evapotranspiration. Mature tree water requirement $\left(E T_{m}\right)$ is $E T_{m}=K c b . E T o$, assuming no soil water evaporation. Two lysimeters were used, one that was $1.6-\mathrm{m}$ diameter and $0.7-\mathrm{m}$ deep, and the other that was $2.7-\mathrm{m}$ diameter and $0.8-\mathrm{m}$ deep. The first one was used to calculate evaporation and the second one was used for transpiration. ETo was estimated by the Penman-Monteith method (FAO-56). The measurements were conducted during a period between August 2002 and April 2005 in Piracicaba, Sao Paulo State, Brazil. The lysimeters were installed at the center of a 1.0ha plot planted with 'Tahiti' acid lime trees grafted on 'Swingle' citrumelo rootstock. The trees were 1 -yr old at planting, spaced $7 \times 4-\mathrm{m}$, and were irrigated by a drip irrigation system. During the study period, $K c$ varied between 0.6 to 1.22 , and $K c b$ varied between 0.4 to 1.0. The results suggested that for young lime trees, the volume of water per tree calculated by $K e+K c b$ is about $80 \%$ higher than the volume calculated using $K c$. For mature tree, the volume of water per tree calculated using just $K c b$ can be $15 \%$ less than using $K c$. The independent influence of soil evaporation and transpiration is important to better understand the water consumption of young lime tree during the growth, compared to mature lime tree.

Keywords: Evapotranspiration; Citrus latifolia Tanaka; irrigation; $K c$; $K c b$; trikle irrigation

\subsection{Introdução}

O Estado de São Paulo é um dos mais importantes produtores de citros do mundo. São Paulo tem 651 mil hectares de citrus cultivado (USDA, 2005), correspondendo a cerca de $82,4 \%$ do total da área de citrus cultivado no país (FNP, 2004). É estimado que cerca de $15 \%$ desse total esta sobre irrigação (PARSONS, 2005). Cerca de $65 \%$ da área de citrus irrigada usa irrigação localizada e os outros 35\% usa sistema de aspersão (NEVES et al., 2004). Recentes estudos indicam que houve um significante incremento na área irrigada durante os últimos 5 anos. Como consequência, a competição pelos recursos hídricos, que é limitado, esta aumentando. A irrigação localizada é prefedida dentre os outros métodos, devido a escasses de água. Informações sobre requerimento de água de plantas cítricas é limitado na região. Portanto, aumentar o conhecimento sobre 
os fatores que afetam o consumo de água de citrus é essencial para otimizar o volume e o tempo de irrigação, usando a água mais eficientemente nesta área.

A expansão permanente sob sistema de irrigação localizada na citricultura Paulista tem mudado o foco da determinação do tempo e quantidade de irrigação. Os coeficientes de cultivo para estimar a evapotranspiração da cultura (ETc) são portanto importantes nos processos de manejo da irrigação. Maior número de pesquisa tem sido para determinar o requerimento de água em culturas anuais e um menor número, em culturas perenes. Por exemplo, a aproximação da FAO (DOORENBOS; PRUITT, 1977), a qual apresenta o requerimento de água para as principais culturas tem sido extremante utilizado em todas as partes do mundo por causa do bom nível de precisão combinado com o fácil uso e transferibilidade para os irrigantes. Entretanto, informações específicas para culturas de plantas isoladas é limitado na publicação da FAO. Mesmo a recente revisão de Allen et al. (1998), a qual apresentou melhoraria na estimativa da evapotranspiração de referência (ETo), não adicionou muita informação em coeficientes de cultivo $(K c)$ para culturas perenes.

Há algumas diferenças fundamentais entre $K c$ de culturas anuais (herbaceas) e culturas de árvores. No caso de culturas herbaceas, $K c$ varia somente sazonalmente e esta variação está ligada a facilidade de detectar as variações dos estágios fenológicos. $K c$ é bem definido pelo valor inicial, máximo e final. O $K c$ em árvores descontinuas também varia sazonalmente, mas isto é afetado por adicionais fatores tais como: arquitetura da copa, densidade de árvores, sistema de poda, colheita, método de irrigação, e manejo da superfície do solo (FERERES; GOLDHAMER, 1990; GOODWIN et al., 2006). Além disso, mesmo em plantas adultas, manejo intensivo de pomar, a cobertura total da área não é nunca atingida por razões horticulturais, então o $K c$ é sempre influenciado pela evaporação de água no solo. Um máximo valor de $K c$ (cobertura total do solo), é muito útil em culturas herbaceas, e o mesmo nao é preciso em pomares.

Uma estimative de ETc para uma cultura específica é calculado pela multiplicação da evapotranspiração de referência $(E T o)$ pelo coeficiente de cultivo $(K c)$ específico para uma determinada cultura, estágio de crescimento, e condições de cultivo. A ETc 
resultará a estimativa do uso de água de uma cultura sob condições climáticas locais ou regionais (ALLEN et al., 1998).

Muitos pesquisadores (ROGERS et al., 1983; CASTEL et al., 1987; VIEIRA; RIBEIRO, 1993; BOMAN, 1994; MARTIN et al., 1997; BERTONHA, 1997; SILVA et al., 2005; MORGAN et al., 2006) estabeleceram uma relação entre ETc de citrus e Kc. Entretanto, os valores de $K c$ destes estudos foram determinados considerando um pomar cítrico como um campo cultivado com cultura herbacea.

$\mathrm{O}$ ajuste do $K c$ de um pomar para uso em irrigação localizada sob copa da planta foi empiricamente desenvolvido no passado por Keller e Karmeli (1975). Eles propuseram uma equação que ajusta a taxa de uso de água em área total para área de cobertura da copa. Entretanto, para plantas jovens com baixa cobertura da copa, o Kc é estremamente afetado pelas condições que influenciam a evaporação da superfície do solo (RITCHIE, 1972; VILLALOBOS et al., 2000). Portanto, Allen et al. (1998) considerou a independente contribuição da evaporação do solo e a transpiração da cultura pela substituição do coeficiente de cultivo $(K c)$ por dois coeficentes distintos; $K e$, um coeficiente de evaporação do solo e $K c b$, um coeficiente de transpiração (referido como basal coeficente de transpiração da cultura). Por esta formulação, o requerimento de água da cultura é dado por $(E T c)=(K c b+K e)$.ETo onde ETo é a evapotranspiração de referência. A aproximação foi originalmente desenvolvida para melhorar a estimativa diária de uso de plantas cultivadas em renque (WRIGHT, 1982), mas isto pode ser igualmente aplicado para pomares sob condições onde o udo de água da planta é estimado pela transpiração $(T)(T=K c b . E T o)$ e a evaporacao do solo $(E s)(E s=K e . E T o)$. A aproximação de Allen et al. (1998) é uma simplificação do complexo físico onde o uso de água de copas descontínuas é considerado em termos de duas partes independentes. Shuttleworth e Wallace (1985) apresentaram uma formal análise do uso da água para estes dois separados sistemas. O componente transpiração de um pomar pode ser relatado pela ETo usando a área efetiva de sobreamento do solo pela copa da planta (GOODWIN, et al., 2006). Orgaz et al. (2006) descreveu que ETc de pomar sob irrigação localizada tem 4 componentes básicos: (a) transpiração da planta como uma função do tamanho da planta e período do ano; (b) chuva interceptada e diretamente 
evaporada da foliagem, como uma função da cobertura do solo e frequência de molhamento da copa; (c) evaporação da superfície do solo, a qual é função principalmente do tempo médio que a superfície total do solo mantém-se molhada e o sombreamento da copa; e (d) evaporação da área molhada pelos emissores, a qual depende da fração da superfície de solo molhada e da frequência de irrigação. Devido a dificuldade de quantificar cada um destes componente separadamente, muitos estudos indicam o método de lisímetria de pesagem como um modo de integrar todos estes componentes, Castel (1997) e Yang et al. (2003).

Dentre os métodos diretos de medir a evapotranspiração, o método de lisímetria de pesagem é o de maior acurácia (HOWEL et al., 1985; SILVA et al., 1999). Informações sobre dimensinamento e operação deste equipamento pode ser obtido em Aboukhaled et al. (1982); Allen et al. (1991); e Campeche (2002).

Portanto, o objetivo deste estudo foi obter ETc e $K c$ de uma planta de lima ácida 'Tahiti' em Piracicaba, São Paulo, usando o método tradicional, considerando citrus como uma cultura herbacea (copa continua), e obter o $K c b$ como recomendado por Allen et al. (1998), considerando citrus como um cultura de copas descontinuas utilizando o método de lisimetria de pesagem. Um Segundo objetivo foi comparar a estimativa da água requerida estimada pelos dois métodos.

\subsection{Material e Métodos}

\section{Área Experimental}

O estudo foi consuzido durante um período de 3 anos (Agosto de 2002 a Maio de 2005) em uma área de aproximadamente 1,0 ha (Anexo B, Figura 1) com plantas de lima ácida 'Tahiti' [Citrus latifolia (Yu. Tanaka) Tanaka cv. IAC 5], enxertada em citrumelo 'Swingle' [Poncirus trifoliata (L.) Raf. $\times$ Citrus paradisi Macf.]. As plantas estavam com 1 ano de idade após o plantio e espaçadas a $7 \times 4 \mathrm{~m}$ (Anexo B, Figura 2), e irrigadas por gotejamento usando 4 gotejadores com taxa de vazão de $4 \mathrm{~L} \mathrm{~h}^{-1}$ para cada planta (Anexo A, Tabela 1). O pomar foi localizado em Piracicaba, São Paulo (22 $41^{\circ} 58^{\prime}$ 'S $47^{\circ} 38^{\prime} 42^{\prime}$ 'W; altitude $\left.511 \mathrm{~m}\right)$. Média anual de temperature na área foi de 
$21,4^{\circ} \mathrm{C}$ e total annual de chuva foi $1257 \mathrm{~mm}$. O solo foi um Nitossolo Vermelho (Embrapa, 1999), textura argilosa, com 5\% de declividade média. A disponibilidade de água para planta foi $125 \mathrm{~m}^{3} \mathrm{~m}^{-3}$. A densidade média do solo entre $0,2 \mathrm{~m}$ a $1 \mathrm{~m}$ de profundidade foi $1,3 \mathrm{Mgm}^{-3}$. Os tratos culurais consistiram de pulverizações com inseticidas, roçagem nas entrelinhas, capinas manuais intercaladas com aplicação de herbicidas na linha de plantio. A adubação (Anexo A, Tabela 1) foi feita de acordo com a recomendação de Raij et al. (1992).

\section{Medidas do lisímetro e Evapotranspiração de referência (ETo)}

Um lisímetro de pesagem (2,7 $\mathrm{m}$ de diâmetro x $0,8 \mathrm{~m}$ de profundidade) com $0,268 \mathrm{~kg}$ de exatidão contendo uma planta, foi instalado próximo ao centro da área experimental (Anexo B, Figura 1). Maiores detalhes sobre a construção e calibração deste equipamento podem ser obtidos em Campeche (2002). A massa do lisimetro foi continuamente medida a cada segundo e valores médios foram registrados a cada hora. Para o cálculo da evapotranspiração da cultura $(E T c)$ diária foi considerado apenas o valor instantâneo, registrado a meia noite de cada dia, quando o elemento meteorológico vento era nulo ou fraco $\left(<1,5 \mathrm{~m} \mathrm{~s}^{-1}\right)$. Além disso, valores inconsistentes foram detectados e descartados especialemente em dias com chuva, sugerindo que a quantidade de chuva efetivamente coletada pelo lisímetro foi diferente da registrada pelo pluviômetro, distante $70 \mathrm{~m}$ do lisimetro. Problemas similares na determinação da ETc ocorreram com Castel (1997). A planta no lisímetro foi irrigada e manejada como o restante das plantas na área experimental.

A evapotranspiração de referência (ETo) foi estimada pelo modelo de PenmanMonteith (ALLEN et al., 1998). Os dados meteorológicos para o período foram coletados por uma estação meteorológica automatizada (Campbell Scientific, Logan, USA) localizada a $70 \mathrm{~m}$ distante do pomar.

\section{Transpiração (T) e coeficiente basal de transpiração da cultura (Kcb)}

Diariamente variações no peso do lisímetro foram registradas e $T$ e $K c b$ foram estimados (Equações de 1 a 6) considerando a individual contribuição da evaporação do 
solo e transpiração da cultura pela substituição do coeficiente de cultivo $(K c)$ por dois coeficientes; Ke (Equação 1), um coeficiente de evaporação do solo e Kcb (Equação 2), um coeficiente de transpiração da planta (ALLEN et al., 1998).

$$
K e=\frac{E s}{E T o}
$$

Onde,

Es: Evaporação do solo

ETo: evapotranspiração de referência $(\mathrm{mm})$;

$$
K c b=\frac{T}{E T o}
$$

Onde,

$T(\mathrm{~mm})$ é a água transpirada da planta (Equação 3).

$$
T=\frac{\left[\left(M_{i}-M_{i-1}-D+P^{*} A+I\right)-E s\right]}{A_{c}}
$$

Onde, $M_{i}$ é a massa do lisímetro (kg); $M_{i-1}$ é a massa do lisímetro no dia anterior $(\mathrm{kg}) ; D$ é a Drenagem $(\mathrm{kg}) ; P$ é a chuva $(\mathrm{mm}) ; I$ é a irrigação $(\mathrm{kg}) ; A_{c}$ é área da copa $\left(\mathrm{m}^{2}\right)$ e $E s$ é a água evaporada da superfície do solo.

A transpiração foi obitida por diferença entre medidas de massas do lisímetro, deduzido a chuva, irrigação, drenagem e a evaporação do solo e dividido pela área sombreada pela copa como descrito por Goodwin et al. (2006).

Estimativa de Es é como segue (Equação 4). 


$$
E s=\frac{(E w+E d)}{A}
$$

Onde $E w(\mathrm{~mm})$ é a água evaporada da área molhada, $E d(\mathrm{~mm})$ é a água do solo seco, e $A$ é área do lisímetro $\left(5.72 \mathrm{~m}^{2}\right)$;

Ew da Equação 5 foi estimada por uma curva de evaporação de água do solo (Figura 1) obtida separadamente para o inverno e verão como uma função de dias após a irrigação. Esta foi estimada usando um segundo lisímetro de pesagem $(1,6 \mathrm{~m}$ de diâmetro e $0,7 \mathrm{~m}$ de profundidade) contendo solo e localizado no pomar como descrito por Silva (2005). Para a frequência de irrigação de 2 dias, a área molhada de cada gotejador $(A w)$ foi $0,28 \mathrm{~m}^{2}$, para um total de área molhada de $1,13 \mathrm{~m}^{2}$ por planta $(4$ gotejadores por planta). Ed (Equação 6) foi estimado usando a curva de evaporação do solo (Figura 1) como uma função da frequência de chuva de cada mês (Figura 2), considerando a área seca $(A d)$ dentro do lisímetro ser de $4,59 \mathrm{~m}^{2}(A-A w)$. Foi considerado como dia de chuva uma preciptação de $\geq 5 \mathrm{~mm}$ por dia.

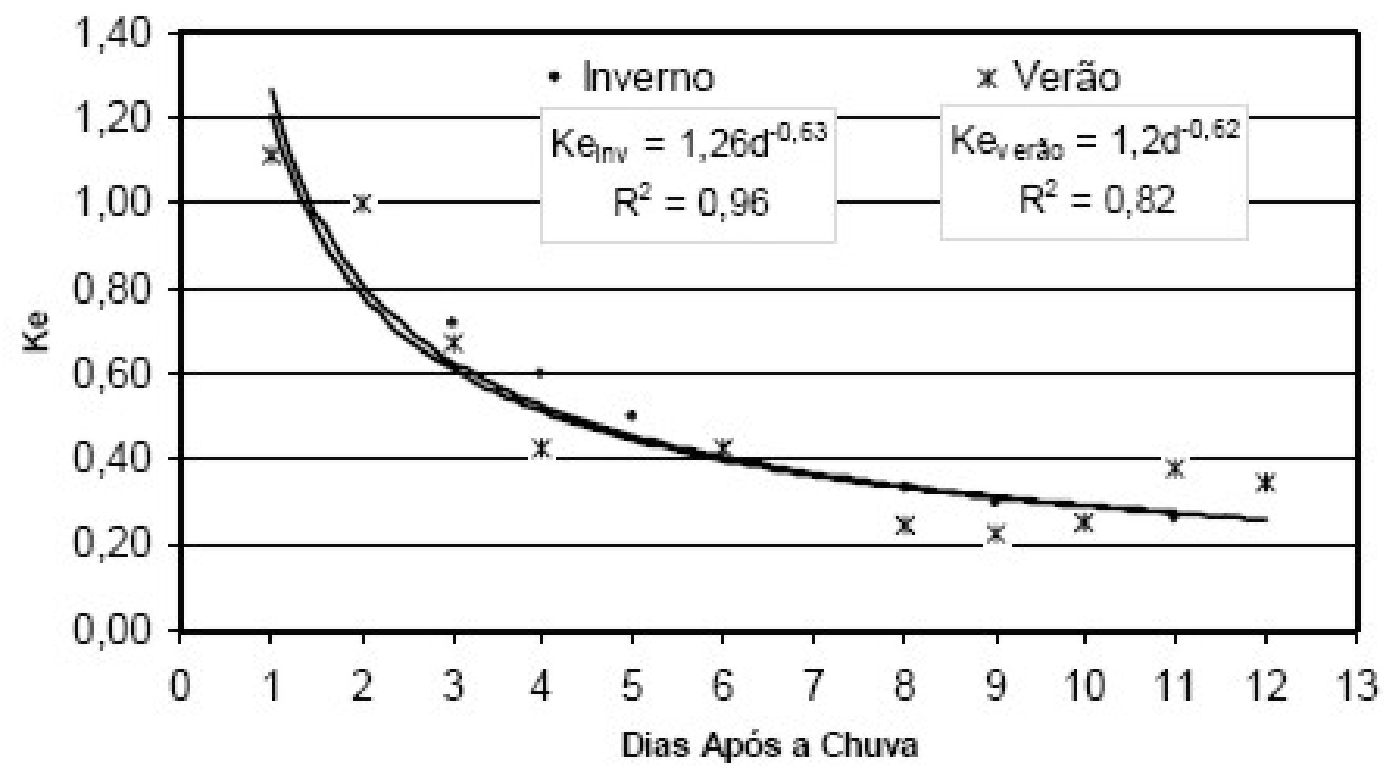

Figura 1 - Curvas de evaporação de água no solo, $K e$, em um Nitossolo Vermelho, textura argilosa, no inverno e verão de Piracicaba, São Paulo. d: Dias após chuva ou irrigação 


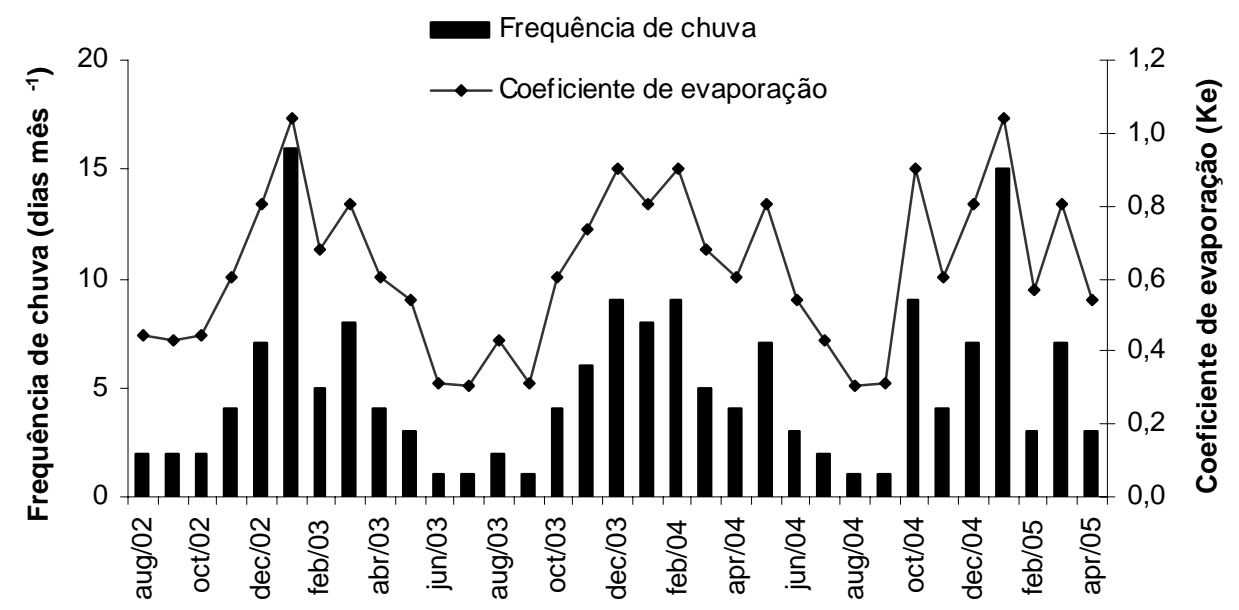

Figura 2 - Frequência de chuva e coeficiente de evaporação estimado $(K e)$ por mês, durante Agosto de 2002 e Abril de 2005 em Piracicaba, São Paulo. Foi considerado como dia de chuva preciptacões $\geq 5 \mathrm{~mm}$ por dia

$$
\begin{aligned}
& E w=K e_{1} * E T o * A w \\
& E d=K e_{2} * E T o * A d
\end{aligned}
$$

$K e_{1}=1,0$ é o coeficiente de evaporação para uma frequência de irrigação de 2 dias. Valores obtidos para média de $\mathrm{Ke}$ do primeiro e segundo dia após a irrigação (Figura 1); $\mathrm{Ke}_{2}$ é o coeficiente de evaporação em função da frequência de chuva em cada mês (Figura 2); ETo é a evapotranspiração de referência $(\mathrm{mm}) ; \mathrm{Aw}=1,13 \mathrm{~m}^{2}$ é a área molhada, e $A d=4,59 \mathrm{~m}^{2}$ é área seca dentro do lisímetro. 


\section{Evapotranspiração da cultura (ETc) e coeficiente de cultivo (Kc)}

A evapotranspiração da cultura $(E T c)$ foi estimado dividindo o consumo total de água da planta (TWC) pela área $28 \mathrm{~m}^{2}$ (7 $\mathrm{m} \mathrm{x} 4 \mathrm{~m}$ ) alocada para cada planta (Equação 7) e Kc pela ralação ETc/ETo (ALLEN et al., 1998).

$$
E T c=\frac{T W C}{A_{t}}
$$

Onde, ETc é a evapotranspiração da cultura (mm); TWC é o consumo total de água da planta (Litros) e $A_{t}$ é a área alocada para cada planta $\left(28 \mathrm{~m}^{2}\right)$.

TWC é a diferença entre duas consecutivas medidas de massa do lisímetro, subtraído a chuva, irrigação e drenagem ocorrida durante o mesmo período no lisímetro $\left(5,72 \mathrm{~m}^{2}\right)$ e somado a evaporação da água no solo da área externa ao lisímetro $\left(22,28 \mathrm{~m}^{2}\right)$ complementar a área do lisímetro $\left(5,72 \mathrm{~m}^{2}\right)$, (Equação 8$)$ totalizando área alocada para cada planta de $28 \mathrm{~m}^{2}(7 \mathrm{~m} \times 4 \mathrm{~m})$.

$$
\mathrm{TWC}=\left[\left(M_{i}-M_{i-1}-D+P . A+I\right)+\left(E d^{*} A_{e}\right)\right]
$$

Onde, $T W C$ é o consumo total de água de uma planta (L), $M_{i}$ é a massa do lisímetro $(\mathrm{kg})$; $M_{i-1}$ é a massa do lisímetro do dia anterior $(\mathrm{kg}) ; D$ é a Drenagem $(\mathrm{kg}) ; P$ é a chuva (mm); $A$ é a área do lisímetro $\left(5,72 \mathrm{~m}^{2}\right) ; I$ é a irrigação $(\mathrm{kg}) ; E d(\mathrm{~mm})$ é a água evaporada da solo seco e $A_{e}$ é a área externa do lisímetro $\left(22,28 \mathrm{~m}^{2}\right)$ complementar a área do lisímetro $\left(5,72 \mathrm{~m}^{2}\right)$, totalizando a área alocada para cada planta de $28 \mathrm{~m}^{2}(7 \mathrm{~m} \times 4 \mathrm{~m})$.

$\mathrm{O}$ ajuste do $K c$ foi feito empiricamente como recomendado por Keller e Karmeli (1975). Eles propuseram uma equação (Equação 9) que ajusta a taxa de uso da água para copas de baixa cobertura do solo.

$$
K c=\left(\frac{E T c}{E T o}\right) *\left(\frac{D C}{0.85}\right)
$$


Onde, $D C$ é o grau de cobertura da área pela cultura. $D C$ é a relação $A_{c} / A_{t}$ (decimal). $A_{c}$ é a área de cobertura da copa $\left(\mathrm{m}^{2}\right)$ e $A_{t}$ é área $28 \mathrm{~m}^{2}(7 \mathrm{~m} \mathrm{x} 4 \mathrm{~m})$ alocada para cada planta.

\subsection{Resultados e Discussão}

\section{Evapotranspiração da cultura (ETc) e coeficiente de cultivo (Kc)}

As médias diárias de ETo (Tabela 1) variaram de um valor baixo de 2,2 $\mathrm{mm} \mathrm{dia}^{-1}$ em Maio de 2004 a um valor alto de 5,2 $\mathrm{mm} \mathrm{dia}^{-1}$ em Novembro de 2003. A ETc diária (Tabela 1) foi menor que a ETo no inverno (período de seca) e igual, ou maior no verão (período úmido). ETc aproximou ou superou ETo entre Outubro e Abril durante o período de avaliação (2002 a 2005). Isto é provavelmente devido a alta ocorrência de chuva e radiação durante o período de verão (período chuvoso). $\mathrm{Na}$ média ( 3 anos), o total de chuva e radiação global média de Outubro a Abril foram de 1071,7 mm e $579,6 \mathrm{MJ} \mathrm{m}^{-2} \mathrm{mes}^{-1}$. 
Tabela 1 - Estimativa diária da evoptranspiração de referência (ETo) e da tradicional evapotranspiração da cultura (ETc) de lima ácida 'Tahiti', por mês

\begin{tabular}{|c|c|c|c|c|c|c|c|c|c|c|}
\hline \multirow{3}{*}{\multicolumn{2}{|c|}{$\begin{array}{l}\text { Idade do } \\
\text { Pomar } \\
\text { Meses }\end{array}$}} & \multicolumn{3}{|c|}{$\begin{array}{c}\text { ET de Referência } \\
(E T o)\end{array}$} & \multirow[b]{2}{*}{ DevPd } & \multicolumn{3}{|c|}{ ET da Cultura (ETc) } & \multirow{3}{*}{ DevPd } & \multirow{3}{*}{$(K c)$} \\
\hline & & Máx. & Mín. & Média & & Máx. & Mín. & Média & & \\
\hline & & \multicolumn{7}{|c|}{$\mathrm{mm} \mathrm{d}^{-1}$} & & \\
\hline & 2002 & & & & & & & & & \\
\hline 14 & Ago & 4,16 & 1,82 & 3,34 & 0,63 & 2,14 & 1,03 & 1,54 & 0,34 & 0,46 \\
\hline 15 & Set & 5,57 & 1,33 & 3,70 & 1,16 & 2,52 & 0,74 & 1,64 & 0,51 & 0,44 \\
\hline 16 & Out & 6,27 & 3,89 & 5,12 & 0,90 & 3,22 & 0,97 & 2,45 & 0,49 & 0,48 \\
\hline 17 & Nov & 5,83 & 2,46 & 4,70 & 0,97 & 3,80 & 1,80 & 3,00 & 0,61 & 0,64 \\
\hline \multirow[t]{2}{*}{18} & Dez & 6,38 & 2,38 & 4,46 & 1,19 & 5,03 & 2,44 & 3,77 & 0,82 & 0,85 \\
\hline & 2003 & & & & & & & & & \\
\hline 19 & Jan & 5,96 & 2,76 & 4,15 & 1,06 & 5,72 & 3,34 & 4,23 & 0,86 & 1,02 \\
\hline 20 & $\mathrm{Fev}$ & 5,90 & 1,72 & 4,80 & 1,10 & 4,63 & 1,67 & 3,77 & 0,77 & 0,78 \\
\hline 21 & Mar & 5,57 & 3,73 & 4,45 & 0,53 & 4,83 & 3,50 & 4,02 & 0,39 & 0,90 \\
\hline 22 & $\mathrm{Abr}$ & 4,55 & 2,72 & 3,59 & 0,56 & 3,25 & 2,11 & 2,67 & 0,32 & 0,74 \\
\hline 23 & Mai & 3,69 & 1,53 & 2,90 & 0,51 & 2,59 & 1,09 & 1,95 & 0,34 & 0,67 \\
\hline 24 & Jun & 3,25 & 2,10 & 2,71 & 0,38 & 1,64 & 0,98 & 1,31 & 0,16 & 0,48 \\
\hline 25 & Jul & 4,21 & 1,93 & 3,04 & 0,68 & 1,81 & 1,08 & 1,43 & 0,22 & 0,47 \\
\hline 26 & Ago & 4,46 & 1,53 & 3,07 & 0,75 & 2,13 & 0,94 & 1,67 & 0,32 & 0,54 \\
\hline 27 & Set & 5,29 & 1,53 & 3,57 & 1,15 & 2,34 & 0,88 & 1,68 & 0,45 & 0,47 \\
\hline 28 & Out & 5,56 & 3,44 & 4,74 & 0,63 & 3,96 & 2,43 & 3,45 & 0,45 & 0,73 \\
\hline 29 & Nov & 6,33 & 4,48 & 5,23 & 0,66 & 5,03 & 3,57 & 4,28 & 0,43 & 0,82 \\
\hline \multirow[t]{2}{*}{30} & Dez & 5,90 & 3,17 & 4,34 & 1,01 & 6,33 & 3,57 & 4,90 & 1,01 & 1,13 \\
\hline & 2004 & & & & & & & & & \\
\hline 31 & Jan & 6,69 & 1,87 & 4,75 & 1,23 & 5,80 & 1,99 & 4,70 & 1,05 & 0,99 \\
\hline 32 & $\mathrm{Fev}$ & 6,00 & 3,15 & 4,61 & 0,87 & 6,16 & 3,46 & 4,85 & 0,83 & 1,05 \\
\hline 33 & Mar & 5,29 & 3,85 & 4,62 & 0,52 & 4,57 & 3,07 & 3,87 & 0,57 & 0,84 \\
\hline 34 & Abr & 3,47 & 1,44 & 2,82 & 0,85 & 2,75 & 1,24 & 2,29 & 0,63 & 0,81 \\
\hline 35 & Mai & 3,72 & 1,18 & 2,24 & 0,61 & 3,15 & 1,17 & 2,10 & 0,49 & 0,94 \\
\hline 36 & Jun & 3,16 & 0,88 & 2,34 & 0,53 & 1,99 & 1,20 & 1,63 & 0,23 & 0,70 \\
\hline 37 & Jul & 3,29 & 0,79 & 2,48 & 0,64 & 1,91 & 0,67 & 1,47 & 0,33 & 0,59 \\
\hline 38 & Ago & 4,52 & 1,35 & 3,32 & 0,68 & 2,33 & 1,00 & 1,65 & 0,36 & 0,50 \\
\hline 39 & Set & 5,49 & 1,95 & 4,30 & 0,86 & 3,00 & 1,26 & 2,43 & 0,39 & 0,56 \\
\hline 40 & Out & 5,36 & 0,32 & 3,35 & 1,59 & 6,12 & 1,09 & 3,79 & 1,38 & 1,13 \\
\hline 41 & Nov & 6,19 & 1,18 & 4,23 & 1,49 & 5,35 & 1,25 & 3,80 & 1,15 & 0,90 \\
\hline \multirow[t]{2}{*}{42} & Dez & 6,19 & 1,71 & 4,03 & 1,25 & 7,01 & 2,69 & 5,05 & 1,06 & 1,25 \\
\hline & 2005 & & & & & & & & & \\
\hline 43 & Jan & 6,14 & 1,20 & 3,49 & 1,49 & 7,95 & 1,83 & 4,99 & 1,70 & 1,43 \\
\hline 44 & $\mathrm{Fev}$ & 6,31 & 2,87 & 4,94 & 0,79 & 5,58 & 3,45 & 4,70 & 0,59 & 0,95 \\
\hline 45 & Mar & 5,40 & 1,59 & 3,60 & 1,15 & 6,49 & 2,07 & 5,04 & 1,09 & 1,40 \\
\hline 46 & Abr & 4,82 & 0,88 & 3,68 & 1,01 & 5,10 & 2,44 & 4,06 & 0,78 & 1,10 \\
\hline
\end{tabular}


Média diária de ETc (Tabela 1) variou de um valor baixo de $1,3 \mathrm{~mm} \mathrm{dia}^{-1} \mathrm{em}$ Junho de 2003 e 1,5 mm dia ${ }^{-1}$ em Julho de 2004 (inverno) a um valor maior de 4,9 mm dia $^{-1}$ em Dezembro de 2003 e 5,0 $\mathrm{mm} \mathrm{dia}^{-1}$ em Janeiro e Março de 2005 (verão). Média de $K c$ (Tabela 1) variou de um baixo valor de 0,57 quando a planta estava com 14 a 18 meses de idade (Agosto a Dezembro de 2002), 0,77 quando 19 a 24 meses de idade (Janeiro a Junho de 2003), 0,69 quando 25 a 30 meses de idade (Julho a Dezembro de 2003), 0,89 quando 31 a 36 meses de idade (Janeiro a Junho de 2004), 0,82 quando 37 a 42 meses de idade (Julho a dezembro de 2004), e a um alto valor de 1,22 quando estava com 43 a 47 meses de idade (Janeiro a Abril de 2005).

Os valores de $K c$ determinados aqui são similares aos medidos em clima úmido por outros pesquisadores (ROGERS et al., 1983; BOMAN, 1994; DOORENBOS; PRUITT, 1977; CASTEL et al., 1987). Por exemplo na Flórida-EUA, Rogers et al. (1983) reportaram medidas mensais de ETc/ETo usando a média de 4 métodos de estimativa de ETo (Penman, Blaney-Criddle, Jensen-Haise, and Tanque Classe 'A'). Os resultados mensais da relação variou de 0,9 em Janeiro (inverno) a 1,11 em Junho (verão). Boman (1994) calculou valores de $K c$ para plantas de laranja 'Valencia' de 5 anos cultivas em taboleiros com água mantida a $0,6,0,75$, ou $0,9 \mathrm{~m}$ da superfície do solo. Valores de $K c$ calculados foram de um mínimo de 0,6 durante Dezembro a Fevereiro (inverno) e máximo de 1,1 em Junho e Julho (verão). Castel et al. (1987) estimou mensalmente $K c$ para plantas adultas de laranja navel cultivada em Valência, Espanha. Estes valores de $K c$ foram calculados da média diária de ETc estimada mensalmente por medidas de água no solo por sonda de nêutros. Os valores variaram de 0,71 de Janeiro a Julho a 0,90 de Agosto a Dezembro. No Mediterrâneo, os valores de $K c$ de citros reportados por Doorenbos e Pruitt (1977) após ajuste para condições úmidas variou de 0,9 de Março até Dezembro a 0,95 para Janeiro e Fevereiro. Este atual estudo está em concordância com Martin et al. (1997), que estimou valores médios diários de ETc para grapefruit 'Redblush' de 7 anos de idade no Arizona sob condições áridas. Valores mensais de $K c$ foram calculados pela relação destas estimativas com valores diários de ETo para o mesmo período. Resultando valores de $K c$ que variaram de 0,550,6 em Dezembro e Janeiro (inverno) a 1,1-1,2 em Julho (verão). 
Em contraste ao atual estudo, em São Paulo, Vieira e Ribeiro (1993) mostraram $K c=0,8$ para planta adulta de lima ácida 'Tahiti' enxertada em limão 'cravo'. Isto foi provavelmente devido as diferenças entre variedades, porta-enxerto, espaçamento, idade, solo e método de medida. Bertonha (1997) estimou $K c=0,75$ para plantas de laranja 'Pera' enxertada em limão 'Cravo' de 4 de idade, e $K c=1.0$ para laranja 'Baianinha' e 'Hamlin' enxertada em laranja 'Caipira' e limao 'Cravo', respectivamente. Os dados do presente estudo diferem do $K c$ de laranja estimado por Bertonha (1997) provavelmente porque plantas de limão apresentam maior ETc (cerca de 10 a 20\%) quando comparado a outros citros, porque estas apresentam crescimento e produção durante todo o ano, como descrito por Doorenbos e Pruitt (1977), Morton (1987) e Wright (2000).

\section{Transpiração (T) e coeficiente basal de transpiração da cultura (Kcb)}

Figura 1 mostra duas curvas de evaporação de água do solo, uma para o inverno $\left(K e=1,26 d^{-0,63}\right.$ e $\left.R^{2}=0,95\right)$ e o outro para o verão $\left(K e=1,2 d^{-0,62}\right.$ e $\left.R^{2}=0,82\right)$. As curvas mostraram alta similaridade em evaporação de água na superfície do solo em ambos os períodos. Baixos e altos coeficientes de evaporação $(\mathrm{Ke})$ concidiram com a magnitude da chuva. Por exemplo, no período de pouca chuva o Ke foi baixo e no período de grande quantidade de chuvas o coeficiente foi alto. Na Figura 2 estão apresentados os valores mensais de chuva e Ke. O Ke variou de 0,31 (Julho de 2003 e Agosto de 2004) a 1,04 (Janeiro de 2003 e 2005). Estes valores de $K e$ coincidem com a baixa frequência de chuva (inverno) com somente um dia de chuva por mês, e alta frequência de chuva (verão) com 16 dias de chuva por mês, respectivamente.

Média diária de transpiração (T) (Tabela 2) variou de $0,87 \mathrm{~mm} \mathrm{~d}^{-1}(K c b=0,26) \mathrm{em}$ Agosto de 2002 (planta jovem) e $0,86 \mathrm{~mm} \mathrm{~d}^{-1}(K c b=0,38)$ em Maio de 2004 (inverno) a $4,39 \mathrm{~mm}^{-1}(K c b=1,09)$ em Dezembro de 2004 (verão) e 4,43 $\mathrm{mm} \mathrm{d}^{-1}(K c b=1,21)$ em Abril de 2005 (planta adulta). Resultados similares de sazonalidade da evapotranspiração de citros também foram observadas por Castel (1997), Yang et al. (2003) e Silva et al. (2005). 
Tabela 2 - Área da copa e estimativa diária da transpiração do citros por mês

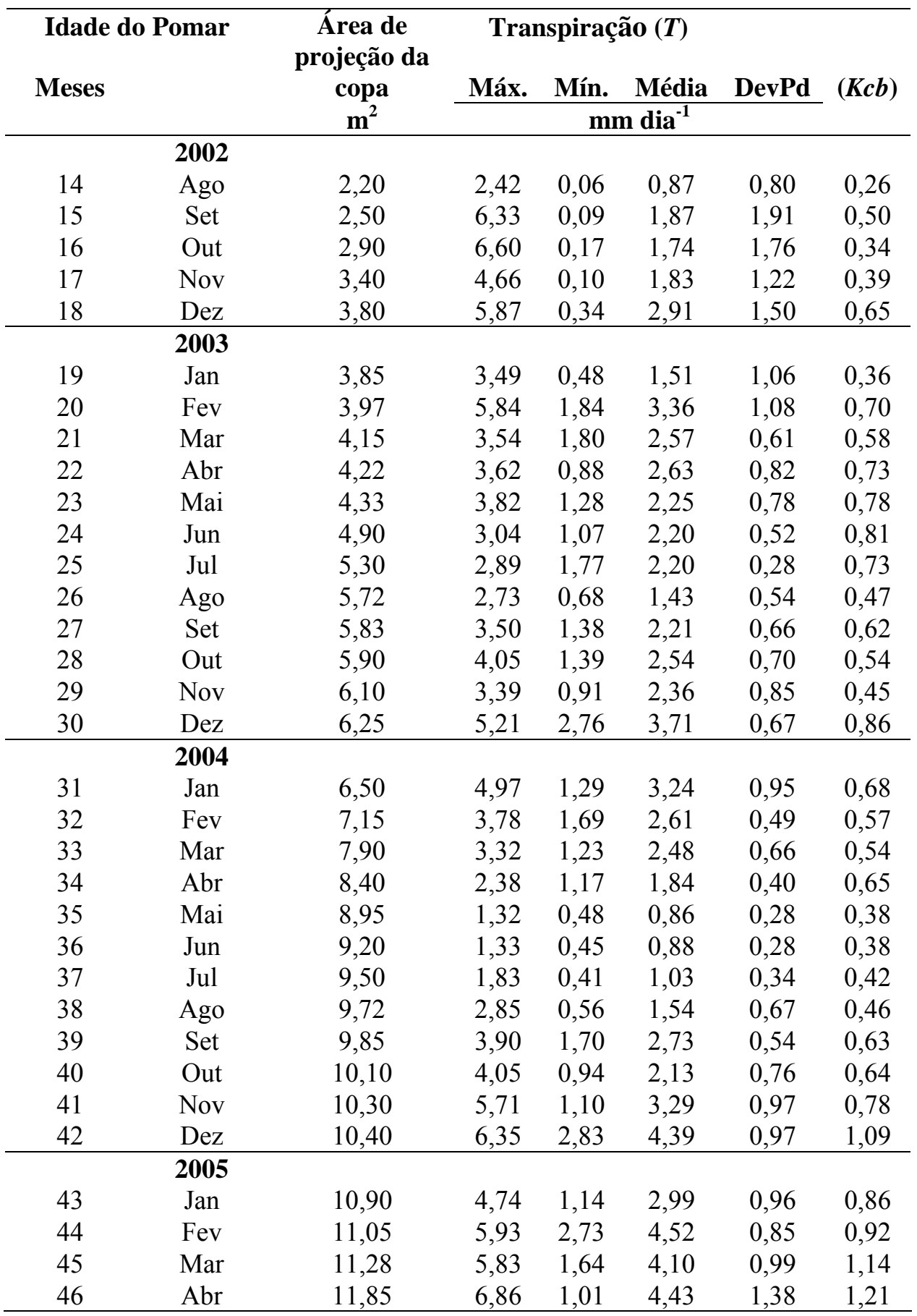

A média de $K c b$ (Tabela 2) variou de 0,43 quando plantas estavam com 14 a 18 meses de idade (Agosto a Dezembro de 2002), 0,66 quando a planta estava entre 19 e 24 
meses (Janeiro a Junho de 2003), 0,61 quando a planta estava com 25 a 30 meses (Julho a Dezembro de 2003), 0,53 quando planta estava com 31 a 36 meses (Janeiro a Junho de 2004), 0,67 quando a planta estava com 37 a 42 meses de idade (Julho a Dezembro de 2004), e de 1,03 guando a planta estava com 43 a 47 meses de idade (Janeiro a Abril de 2005).

Castel (1994) encontrou que $K c b$ para planta jovem de 'Clementina de Nules' (Citrus Clementina, Hort ex Tan.) enxertada em Citrange Carrizo (Citrus sinensis, Osb. X Poncirus trifoliata, Raf.) cultivada em Valência-Espanha pode ser de 0,25 e 0,31. Boman (1994) na Flórida-EUA encontrou que $K c b$ foi 0,26 para plantas jovens de citros. Allen et al. (1998) no Boletin FAO-56 recomendaram valores de $K c b$ entre 0,40 e 0,50. Estes Kcb relatados por Castel (1994), Boman (1994) e Allen et al. (1998) estão em concordância com valores de $K c b$ encontrados no presente estudo (Tabela 2).

Boman et al. (2002) relataram que o uso de água para uma planta de citros durante os dois primeiros anos após o plantio no campo pode ser cerca de $3,8 \mathrm{~L} \mathrm{dia}^{-1}$. Quando comparado com os resultados do presente estudo (Tabela 2), o volume de água estimado estimado acima é suficiente para satisfazer a demanda de transpiração da planta. $\mathrm{O}$ volume de água estimado por Boman et al. (2002) está de acordo com o os valores de transpiração medidos no atual estudo (Tabela 2). A Tabela 3 mostra que a média diária de transpiração de planta foram 4,7, 11,4, 20,1 e 46,5 $\mathrm{L} \mathrm{dia}^{-1}$ durante o segundo, terceiro, quarto e quinto ano das plantas no campo. Resultados similares são relatados por Marin et al (2002). Eles encontraram transpiração diária para planta adulta de $36 \mathrm{~L} \mathrm{dia}^{-1}$ durante o inverno. Portanto, os resultados sugerem que o uso de $K c$ em 0,6-0,7 (Tabela 3) obtida neste estudo (pelo tradicional método) e também relatado por Doorenbos e Pruit (1977) ou o uso do volume de água de $3,8 \mathrm{~L} \mathrm{dia}^{-1}$ por planta como descrito por Boman et al. (2002), não é suficiente para satisfazer o requerimento de água de plantas jovens de citros, durante os primeiros anos no campo. A cobertura do solo por plantas jovens não é suficiente para sombrear o total de área molhada. Daí, a evaporação do solo é alta. Um adicional volume de água deveria ser adicionado para suplementar a evaporação do solo. Este adicional volume de água depende da área molhada e da frequência de irrigação (Figura 1). Tabela 3 mostra que o volume de água para plantas 
jovens como calculado por $K c b+K e$ (considerando alta evaporação do solo em área molhada) é cerca de $80 \%$ maior do que o volume de irrigação calculado usando o tradicional $K c$. O volume de água calculado (Tabela 3) considerando alta evaporação de água do solo $(\mathrm{Kcb}+\mathrm{Ke})$ está em concordância com o volume de água calculado para plantas jovens usando $K c_{\text {adjusted }}$ (Tabela 3), como descrito por Keller e Karmelli (1975).

Tabela 3 - Área média da copa, coeficiente de transpiração da cultura $(K c b)$ e tradicional coeficiente da cultura $(K c)$, transpiração e estimativa do volume de irrigação por $K c b+K e, K c, K c_{a d j u s t e d}$ e $K c b$

\begin{tabular}{|c|c|c|c|c|c|c|c|c|c|}
\hline \multirow[b]{2}{*}{$\begin{array}{c}\text { Idade } \\
\text { Ano } \\
\end{array}$} & \multirow[b]{2}{*}{ Kcb } & \multirow[b]{2}{*}{ Kc } & & \multirow[b]{2}{*}{$\begin{array}{c}\text { Área da } \\
\text { Copa } \\
\text { m²}^{2}\end{array}$} & \multicolumn{4}{|c|}{ Volume de água para irrigação localizada } & \multirow[t]{2}{*}{ Transpiração } \\
\hline & & & & & $(K c b+K e)^{*}$ & $K c^{* *}$ & $\begin{array}{l}\text { Kc } * * * \\
\text { (ajustado) } \\
\text { L planta }^{-1}\end{array}$ & $\begin{array}{l}K c b^{* * * *} \\
\text { lia }\end{array}$ & \\
\hline 1 & 0,43 & 0,57 & 4,26 & 2,96 & 16,08 & 7,83 & 15,15 & 5,78 & 4,75 \\
\hline 2 & 0,63 & 0,73 & 3,88 & 5,04 & 27,96 & 14,83 & 23,13 & 12,23 & 11,44 \\
\hline 3 & 0,60 & 0,86 & 3,59 & 9,00 & 45,82 & 27,72 & 37,56 & 20,28 & 20,12 \\
\hline 4 & 1,03 & 1,22 & 3,93 & 11,27 & 80,71 & 52,82 & 52,01 & 45,34 & 46,53 \\
\hline
\end{tabular}

* Volume $(\mathrm{V})=\left[\left(\mathrm{Ke}^{*} \mathrm{Aw} * \mathrm{ETo}\right)+\left(\mathrm{Kcb}^{*} \mathrm{ETo} * \mathrm{Ac}\right)\right] ; * * \mathrm{~V}=\mathrm{Kc} * \mathrm{ETo} * \mathrm{Ac} ; * * * \mathrm{~V}=\mathrm{Kc} * \mathrm{ETo} * \mathrm{At} ; * * * \mathrm{~V}=\mathrm{Kcb} * \mathrm{ETo} * \mathrm{Ac}$ Aw é a área molhada; Ac é a área de cobertura da copa; $\mathrm{V}$ foi calculado considerando $\mathrm{Aw}=\mathrm{Ac}$; At é área da superfície $28 \mathrm{~m}^{2}(7 \mathrm{~m} \mathrm{x} 4 \mathrm{~m})$ alocado para cada planta; ETo é a evapotranspiração de referência; Kc é o coeficiente de cultivo; $\mathrm{Kcb}$ é o coeficiente de transpiração; $\mathrm{Ke}=0.8$ é o coeficiente de evaporação do solo com 4 dias de frequência de irrigação. $\mathrm{O}$ valor de Ke foi obtido pela média de Ke do primeiro, segundo, terceiro e quarto dia após a irrigação (Figura 1).

Volumes de água similares são recomendados por Coelho et al. (2004). Eles recomendam volumes de $10,15,25,45$ e $65 \mathrm{~L} \mathrm{dia}^{-1}$ por planta de citrus, durante o primeiro, segundo, terceiro, quarto e quinto ano, respectivamente. Crescimento de plantas jovens é estremamente afetados pelo défict hídrico durante os primeiros anos após o plantio (CASTEL; BUJ, 1992; CASTEL, 1993; ALVES Jr. et al., 2004). Portanto, os resultados mostraram que considerando a independente contribuição de evaporação do solo e transpriração em plantas jovens é um importante modo de satisfazer o real requerimento de água da planta.

Boman et al. (2002) estimou que, na Flórida, o requerimento de água de uma planta de laranja 'Valencia' de 6 anos de idade foi cerca de $40 \mathrm{~L} \mathrm{dia}^{-1}\left(57\right.$ e $20 \mathrm{~L} \mathrm{dia}^{-1}$ no verão e inverno, respectivamente). Resultados similares foram encontrados por Coelho 
et al. (1994) no Brasil. Ele relatou que a alta produtividade foi obtida, quando plantas adultas de lima ácida 'Tahiti' foram irrigada por gotejamento com cerca de $30 \mathrm{~L} \mathrm{dia}^{-1}$. Os resultados relatados por Coelho et al. (1994) estão de acordo com o volume de água calculado por Kcb (Tabela 3) estimado neste atual estudo. Portanto, os resultados sugerem que o uso de somente $K c b$ em plantas adultas pode ser suficiente para satisfazer o requerimento de água da planta. Os volumes de água de plantas adultas calculados por $K c$ e $K c_{\text {adjusted }}$ mostraram valores similares (cerca de $52 \mathrm{~L} \mathrm{planta}^{-1} \operatorname{dia}^{-1}$ ). Menor volume de água foi obtido quando calculado por $K c b$ (cerca de $45 \mathrm{~L} \mathrm{planta}^{-1} \mathrm{dia}^{-1}$ ) (Tabela 3). Tabela 3 mostra que o volume de água por planta adulta calculado por $K c b$ pode ser

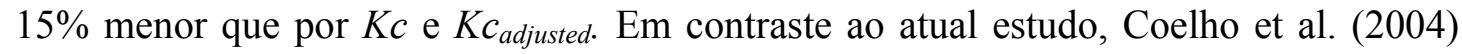
recomendam o volume de água para planta adulta de citros de $100 \mathrm{~L} \mathrm{dia}^{-1}$. Provavelmente, Coelho et al. (2004) consideraram alta evaporação de água sob copa, similar ao volume calculado considerando $K c b+K e$ mostrado na Tabela 3. Portanto, os resultados mostraram que considerando a independente contribuição da evaporação do solo e transpiração de planta adulta pode ser uma ótima alternativa para salvar água em pomares de citros irrigados por irrigação localizada.

\subsection{Conclusão}

A independente influência isolada da evaporação do solo e transpiração é importante para melhor entender o consumo de água de uma planta de Lima ácida 'Tahiti' durante os primeiros estágios de desenvolvimento e em plantas adultas. Para plantas de lima ácida, o volume de água por planta calculado por $K c b+K e$ é cerca de $80 \%$ maior que o volume calculado usando $K c$. Para plantas adultas, o volume de água por planta calculado usando somente $K c b$ pode ser $15 \%$ menor que usando $K c$.

\section{Referências}

ABOUKHALED, A.; ALFARO, A.; SMITH, M.. Lysimeters. Rome: FAO, 1982. 68 p. (FAO. Irrigation and Drainage, 39). 
ALLEN, R.G.; PEREIRA, L.S.; RAES, D.; SMITH, M. Crop evapotranspiration: guindelines for computing crop water requirements. Rome: FAO, 1998. 300 p.

(Guideline, 56)

ALLEN, R.G.; FISCHER, D.K. Direct load cell-based weighing lysimeter system. In: ALLEN, R.G.; HOWELL, T.A.; PRUITT, W.O. (Ed.). Lysimeter for evapotranspiration and environmental measurements. New York: American Society of Civil Engineers, 1991. p. 114-124.

ALVES JUNIOR, J.; SILVA, C.R.; RIBEIRO, R.V.; SILVA, T.J.A.; FOLEGATTI, M.V. Growth of young 'Tahiti' acid lime trees under irrigation levels. Engenharia Agrícola, Botucatu, v. 25, n. 1, p. 170-178, 2005.

BERTONHA, A. Funções de resposta da laranja à aplicação de água e nitrogênio. 1997. 62 p. Tese (Doutorado em Irrigação e Drenagem) - Escola Superior de Agricultura "Luiz de Queiroz", Universidade de São Paulo, Piracicaba, 1997.

BOMAN, B.; PARSONS, L.R. Evapotranspiration. In: BOMAN, B. Water and Florida citrus: use, regulation, irrigation systems and management. Florida: University of Florida, Institute of Food and Agricultural Sciences, 2002. p.163-174.

BOMAN, B.J. Evapotranspiration from young Florida flatwoods citrus trees. Journal of Irrigation and Drainage Engineering, New York, v. 120, n. 1, p. 81-88, 1994.

CAMPECHE, L.F.S. Construção, calibração e análise de funcionamento de lisímetros de pesagem para determinação da evapotranspiração da cultura da lima ácida 'Tahiti' (Citrus latifolia Tan.). 2002. 62 p. Tese (Doutorado em Irrigação e Drenagem) - Escola Superior de Agricultura "Luiz de Queiroz, Universidade de São Paulo, Piracicaba, 2002.

CASTEL, J.R. Response of young Clementine citrus trees to drip irrigation. Acta Horticulturae, Leuven, n. 335, p. 313-324. 1993.

CASTEL, J.R. Response of Young clementine citrus trees to drip irrigation. I. Irrigation amount and number of drippers. Journal of Horticultural Science, Kent, v. 69, n. 3, p. 481-489, 1994.

CASTEL, J.R. Evapotranspiration of a drip-irrigated clementine citrus trees in a weighing lysimeter. Acta Horticulturae, Leuven, n. 449, p. 91-98, 1997.

CASTEL, J.R.; BUJ, A. Growth and evapotranspiration of young, drip-irrigated Clementine trees. Proceedings of the International Society of Citriculture, Acireale, v. 2, p. 651-656, 1992. 
CASTEL, J.R.; BAUTISTA, I.; RAMOS C.; CRUZ, G. Evapotranspiration and irrigation efficiency of mature orange orchards in 'Valencia' (Spain). Irrigation Drainage Systems, Netherlands , v. 3, p. 205-217, 1987.

COELHO, E.F.; MAGALHAES, A.F.J.; COELHO FILHO, M.A. Irrigação e fertirrigação em citros. Cruz das Almas: Embrapa, CNPMF, 2004. 16 p. (Embrapa. CNPMF. Circular Técnica, 72.). Disponível em:

http://www.cnpmf.embrapa.br/publicacoes/circulares/circular 72.pdf. Acesso em: 23 mar. 2006

COELHO, Y.S.; SOBRINHO, A.P.C.; MAGALHÃES, A.F.J.; PASSOS, O.S.; NASCIMENTO, A.S.; SANTOS, H.P.; SOARES FILHO, W.S. A cultura do limão 'Tahiti'. Cruz das Almas: Embrapa, CNPMF; Brasília: Embrapa, SPI, 1994. 46 p. (Embrapa. SPI. Coleção Plantar, 18).

DOOREMBOS, J.; PRUITT, W.O.. Guidelines for predicting crop water requirements. $2^{\text {nd }}$ ed. Rome: FAO, 1977. 179 p. (FAO. Irrigation and Drainage, 24).

ESTADOS UNIDOS. Department of Agriculture. Foreing Agriculture Service. Brazil Citrus: annual report 2005. Gain report BR5026. Global Agriculture Information Network. Disponivel em: http://www.fas.usda.gov/gainfiles/200512/146131807.doc Acesso em: 5 Mar. 2006.

FERERES, E.; GOLDHAMER, D.A. Deciduous fruit and nut trees. In: STEWART, B.A.; NIELSEN, D.R. (Ed.). Irrigation of agricultural crops. Madison: American Society of Agronomy; IRRI, 1990. p. 987-1017. (Monograph ,30).

GOODWIN, I.; WHITFIELD, D.M.; CONNOR, D.J. . Effects of tree size on water use of peach (Prunus persica L. Batsch). Irrigation Science, Berlin, v. 24, n.1, p. 59-68, 2006.

HOWELL, T.A.; MCCORMICK, R.L.; PHENE, C.J.. Design and instalation of large weighing lysimeters. Transactions of the ASAE, St. Joseph, v. 28, n. 117, p. 106-112, 1985.

KELLER, J.; KARMELI, D. Trickle irrigation design. Glendora: Rain Bird Sprinkler Manufacturing Corporation, 1975. $133 \mathrm{p}$.

MARIN, F.R.; ANGELOCCI, L.R.; PEREIRA, A.R.; VILLA NOVA, N.A.; SENTELHAS, P.C. Balanço de energia e consumo hídrico em pomar de lima ácida 'Tahiti'. Revista Brasileira de Meteorologia, São Paulo, v. 17, n. 2, p. 219-228, 2002.

MARTIN, E.C.; HLA, A.K.; WALLER, P.M.; SLACK, D.C. Heat unit-based crop coefficient for grapefruit trees. Applied Engineering in Agriculture, St. Joseph, v. 13, p. $485-489,1997$ 
MORGAN, K.T.; OBREZA, T.A.; SCHOLBERG, J.M.S.; PARSONS, L.R.;

WHEATON, T.A. Citrus water uptake dynamics on a sandy Florida entisol. Soil Science Society of America Journal, Madison, v. 70, p. 90-97, 2006.

MORTON, J.F 'Tahiti' Lime. In: . Fruits of warm climates. 1987. p. 172-175. Disponível em: http://www.hort.purdue.edu/newcrop/morton/tahiti_lime.html. Acesso em: 10 fev. 2006.

NEVES, M.F.; LOPES, F.F.; ROSSI, R.M.; NEVES, E.M.; MARINO, R.K.; FERNANDES, W.B.; SCARE, R.F.; CAMPOS, E.M.; TEIXEIRA, L. Mapeamento e qualificação do sistema agroindustrial citrícola em 2004: Projeto do Programa de estudos dos negócios do sistema agroindustrial. Ribeirão Preto: USP, 2004. Disponível em http://www.pcarp.usp.br/acsi/anterior/808/newpage6.htm. Acesso em: 26 mar. 2006.

ORGAZ, F.; TESTI, L.; VILLALOBOS, F.J.; FERERES, E. Water requirements of olive orchards. II: Determination of crop coefficients for irrigation scheduling.

Irrigation Science, Berlin,v. 24, p. 77-84, 2006.

PARSONS, L.R. Weather and irrigation for the new year. Citrus Industry, Tampa, v.1, n.1, p.16-17, Jan./Feb. 2005

RAIJ, B. van, SILVA, N.M.; BATAGLIA, O.C.; QUAGGIO, J.A.; HIROCE, R.; CANTARELLA, H.; BELLINAZZI, J.R.; DECHEN, A.R.; TRANI, P.E.

Recomendações de adubação e calagem para o Estado de São Paulo. Campinas: IAC, 1992. 107 p. (IAC. Boletim Técnico, 100).

RITCHIE, J.T. Model for prediction evaporation from a row crop with incomplete cover. Agricultural and Forest Meteorology, Amsterdam, v. 121, n. 1/2, p. 1-18, 1972.

ROGERS, J.S.; ALLEN , L.H. Jr.; CALVERT, D.V. Evapotranspiration from a humidregion developing citrus grove with grass cover. Transactions of the ASAE, St. Joseph, v. 83 , p. $1778-1792,1983$.

SHUTTLEWORTH, W.J.; WALLACE, J.S. Evaporation from sparse canopies: an energy combination theory. Quarterly Journal of the Royal Meteorological Society, London, v. 111, p. 839-855, 1985.

SILVA, C.R. Evapotranspiração e desenvolvimento de Limeira Ácida 'Tahiti’ na ausência e presença de estresse hídrico. 2005. 85 p. Tese (Doutorado em Irrigação e Drenagem) Escola Superior de Agricultura "Luiz de Queiroz", Universidade de São Paulo, Piracicaba., 2005. 
SILVA, F.C.; FOLEGATTI, M.V.; PEREIRA, A.R.; VILLA NOVA, N.A. Uso de dispositivos lisimétricos para medida da evapotranspiração de referencia. Revista Brasileira de Agrometeorologia, Santa Maria, v. 7, n. 1, p. 19-23,1999.

VIEIRA, D.B.; RIBEIRO, T.A.P. Estudo de parâmetros básicos de irrigação do limão 'Tahiti' (Citrus limonia OSBECK) sob micro-aspersão. In: CONGRESSO BRASILEIRO DE ENGENHARIA AGRÍCOLA, 19., 1993, Ilhéus. Anais ... Ilhéus: SBEA; CEPLAC, 1993. v. 4, p. 2328-2339.

VILLALOBOS, F.J.; ORGAZ, F.; TESTI, L.; FERERES, E. Measurement and modeling of evapotranspiration of olive (Olea europaea L.) orchards. European Journal of Agronomy, Amsterdam, v. 13, n. 2/3, p. 155-163, 2000.

WRIGHT, G.C. Irrigating citrus trees 2000. University of Arizona. College of Agriculture. Cooperative Extension. 5 p. Disponível em: cals.arizona.edu/pubs/crops/az1151.pdf. Acesso em: 05 abr. 2006.

WRIGHT, J.L. New evapotranspiration crop coefficients. Journal of Irrigation and Drainage Engineering, New York, v. 108, p. 57-74, 1982.

YANG, L.S.; YANO, T.M.A.; LI, X. Evapotranspiration of orange trees in greenhouse lysimeters. Irrigation Science, Berlin, v. 21, n. 4, p. 145 -149, 2003. 


\section{RESPOSTA DE PLANTAS JOVENS DE LIMA ÁCIDA 'TAHITI' A DIFERENTES NÍVEIS DE IRRIGAÇÃO}

\section{Resumo}

Alguns anos atrás, São Paulo era considerada a única região no mundo com alta produção de citrus sem uso de irrigação. Entretanto, recentes estudos mostram que durante os últimos 5 anos, houve um significante incremento na área irrigada de citrus. Além disso, a falta de água e a indisponibilidade de informações para uso eficiente da irrigação são os principais problemas face aos produtores. Portanto, neste estudo foi avaliado o efeito de diferentes níveis de irrigação no crescimento da copa e raízes, na produtividade e qualidade de fruto de plantas jovens de lima ácida 'Tahiti', irrigadas por gotejamento. O experimento foi conduzido durante um período de 3 anos (Agosto de 2002 a Maio de 2005) em uma área de 1,0 ha de plantas de lima ácida 'Tahiti', enxertadas em citrumelo 'Swingle'. As plantas estavam com 1 ano de implantação no campo, espaçadas $7 \times 4 \mathrm{~m}$. O pomar foi localizado em Piracicaba, São Paulo. Cada tratamento foi irrigado com diferentes nívieis de irrigação, baseado na ETc como segue: T1) não irrigado, T2) $25 \%$, T3) 50\%, T4) $75 \%$ e T5) $100 \%$ da ETc determinada por um lisímetro de pesagem. Diâmetro do tronco e altura de planta foram avaliados mensalmente. As raízes foram avaliadas quando as plantas estavam com 30 e 48 meses de idade. Durante a primeira análise de raízes foram utilizados 4 distâncias horizontais do tronco $(0,3,0,6,0,9$ e $1,2 \mathrm{~m})$ e 2 profundidades $(0,0-0,3$ e $0,3-0,6 \mathrm{~m})$. Na segunda análise de raízes foram utilizados 5 distâncias horizontais do tronco $(0,3,0,6,0,9,1,2$ e $1,5 \mathrm{~m})$, e 3 profundidades $(0,0-0,3,0,3-0,6$ e $0,6-0,9 \mathrm{~m})$. A produtividade foi avaliada medindo o peso e o número de frutos por planta em 2004 e 2005 . A qualidade da produção foi avaliada pela medida de diâmentro de fruto, espessura da casca, \% de suco, sólidos soluveis totais, $\mathrm{pH}$ e acidez total. Os resultados mostraram que plantas jovens irrigadas com $100 \%$ da ETc resultaram em maior crescimento. Em plantas com 33 meses de idade, a irrigação não influenciou na distribuição de raízes em profundidade. Entretanto, a irrigação influenciou na distribuição horizontal de raízes. Plantas irrigadas com 75 e 100\% ETc mostraram distribuição horizontal de raízes concentradas a $0,6 \mathrm{~m}$ do tronco. Em plantas com 48 meses de idade, irrigação teve nenhum efeito na distribuição de raízes no perfil do solo. Irrigação não aumentou a qualidade dos frutos. Produtividade foi incrementada em todos os tratamentos irrigados, mas a maior eficiência média de produção por unidade de água aplicada foi obtida nas plantas irrigadas com $25 \%$ da ETc.

Palavras-chave: Manejo da irrigação, citrus, produtividade, qualidade de fruto, distribuição de raízes, crescimento

\footnotetext{
Abstracts

A few years ago, Sao Paulo State in Brazil was considered the only region in the world with the highest production of citrus under no irrigation. However, recent studies
} 
showed that during the last 5 years, there was a significant increase in the area under citrus irrigation. In addition, the shortage of water and the unavailability of required information for efficient irrigation scheduling are the main problems the producers face. Therefore, we evaluated the effect of different irrigation levels on canopy and root growth, productivity and quality of fruit of young 'Tahiti' acid lime trees, under drip irrigation. The experiment was conducted during a 3 yr period (August 2002 - May 2005) in a 1.0-ha plot planted with 'Tahiti' acid lime trees, grafted on 'Swingle' citrumelo rootstock. The trees were 1 -yr old at planting, spaced $7 \times 4 \mathrm{~m}$. The orchard was located in Piracicaba, Sao Paulo State, Brazil. Each treatment was assigned to different irrigation level, based on ETc as follows: T1) non-irrigated, T2) 25\%, T3) 50\%, T4) $75 \%$ and T5) $100 \%$ of ETc as determined by a weighing lysimeter. Trunk diameter and height tree were evaluated monthly. The roots were evaluated when the trees were 30 and 48 months old. Adopted during the first root sampling were 4 horizontal distances from tree trunk $(0.3,0.6,0.9$ and $1.2 \mathrm{~m})$ and 2 depths $(0.0-0.3$ and 0.3-0.6 m). Adopted during the second sampling were 5 horizontal distances from trunk $(0.3,0.6$, $0.9,1.2$ and $1.5 \mathrm{~m})$, and 3 depths $(0.0-0.3,0.3-0.6$ and $0.6-0.9 \mathrm{~m})$. The yield was evaluated by measuring weight and number of fruits per tree in 2004 and 2005 . The quality of the yield was evaluated by measuring fruit diameter, rind thickness, \% of juice, total soluble solids, $\mathrm{pH}$ and total acidity. The results showed that young trees irrigated with $100 \%$ ETc resulted in greater growth. With trees that were 33 months old, irrigation did not influence root distribution in depth. However, irrigation influenced root distribution horizontally. Trees irrigated at 75 and $100 \%$ ETc showed horizontal root distribution concentrated at $0.6 \mathrm{~m}$ from the trunk. With 48 month old trees, irrigation had no effect on root distribution in the soil profile. Irrigation did not improve the quality of fruit. Yield increased in all irrigated treatment, but the most efficient yield mean per unit of water applied was the $25 \%$ ETc treatment.

Keywords: Irrigation scheduling, citrus yield, fruit quality, root distribution, growth

\subsection{Introdução}

O Brasil é o maior produtor mundial de citrus, produzindo cerca de $35 \%$ da produção mundial, e responsável pela exportação de $85 \%$ de todo suco concentrado exportado. Em 2003, o Brasil produzil aproximadamente 15,5 milhões de toneladas (380 milhões de caixas de 40,8 kg cada), correspondendo a US\$ 1,5 bilhões. Estima-se que $82,4 \%$ da produção de citrus do país está concentrada no Estado de São Paulo (FNP, 2004). Há um total de 36 mil hectares de limão em São Paulo, produzindo 609 mil tons, dos quais cerca de $82 \%$ do total produzido no Brasil (FNP, 2003). As exportacões de limão 'Tahiti' foram incrementadas significativamente nas recentes décadas. Em 2001, 
14,8 mil tons foram exportadas, correspondendo a US\$ 7,6 milões (FAO, 2003), colocando o limão como uma das 10 frutas mais importantes para o Brasil (IBGE, 2003). Portanto, permanentes pesquisas são necessárias com o objetivo de incrementar a produtividade e a área cultivada com limão em São Paulo.

A lima ácida 'Tahiti' (Citrus latifolia Tanaka) é dentre as espécies cítricas, a de maior precocidade, apresentando, em geral uma produção significativa já a partir do terceiro ano, mas só a partir do quinto em diante é que começa a expressar rendimentos econômicos (FNP, 2003). Esta espécie se adapta aos diferentes tipos de solo (GAYE, 1991). No Estado de São Paulo a lima ácida pode ser cultivada em todas as regiões, exceto em áreas onde temperaturas do ar (T) são extremas $\left(12{ }^{\circ} \mathrm{C}<\mathrm{T}>39{ }^{\circ} \mathrm{C}\right)$ (ORTOLANI et al., 1991). Por causa do desenvolvimento vegetativo e produção durante todo ano, as plantas de lima ácida demandam cerca de 10-20\% mais irrigação do que as laranjas. Em pomares com grama nas entrelinhas devem receber cerca de 20\% mais água do que em condições sem presença de grama ou qualquer outro tipo de cobertura (DOORENBOS; PUITT, 1977; MORTON, 1987; WRIGHT, 2000).

Até alguns anos atrás, o Estado de São Paulo era considerado a única região no mundo com alta produção de citrus sobre condições não irrigadas. Entretanto, recentes estudos mostram que nos últimos 5 anos, houve um significante aumento da área com irrigação em citrus.

Atualmente, estima-se que $15 \%$ dos 651 mil hectares cultivados em São Paulo (ESTADOS UNIDOS, 2005) recebem irrigação (PARSONS, 2005). Vieira (1988) e Zanini et al. (1998) confirmaram que o uso da irrigação na produção de citrus em São Paulo pode aumentar substancialmente a produtividade e a qualidade de fruto. Em adição, muitos novos pomares estão usando porta-enxertos que são menos tolerantes ao extress hídrico. Esses porta-enxertos são usados principalmente para o controle da Morte Subita do Citrus principamente na região Norte de São Paulo, onde o déficit hídrico é mais severo (FUTCH et al., 2005). Embora o Estado de São Paulo receba anualmente chuvas entre 1200 a $1600 \mathrm{~mm}$, cerca de $80 \%$ das chuvas ocorrem de Outubro a Abril, não coincidindo com os períodos críticos da cultura que vai do florescimento ao pegamento dos frutos. Bustan e Goldschmidt (1998) relatam que no período reprodutivo, 
$70 \%$ do carbono assimilado pela planta é usado para produção de flores e frutos. Estudos mostraram que inadequado quantidade de chuvas durante estes periodos podem significativamente reduzir a produção (VIEIRA, 1991). Por causa das razões acima, a área de citrus irrigada em São Paulo esta aumentando. Entretanto, a falta de água e a indisponibilidade de informações para o manejo eficiente da irrigação são os principais problemas face aos produtores. $\mathrm{O}$ uso excessivo de irrigação resulta na perda de água por percolação profunda e escorrimento superficial, podendo diminuir a qualidade dos frutos, além de promover a lixiviação de nutrientes e aumentar o risco de doenças de raízes. Técnicas que garatem a máxima eficiência do uso da água deve ser usado (BOLLER et al., 2004). Aumentar a eficiência da irrigação reduzindo o desperdício é um importante modo de economizar água sem afetar a produtividade. A água economizada poderá ser utilizada para expandir a área irrigada.

Em regiões chuvosas, irrigação não era considerada ser necessário ou economicamente justivicada para produção de citrus até 1955. Desde 1960, trabalhos na Flórida-USA tem mostrado que a irrigação pode beneficiar crescimento e produtividade do citrus mesmo em clima úmido. As razões para isso inclue variabilidade de chuva, solo com baixa capacidade de retenção de água, e o desenvolvimento de novas tecnologias de irrigação e manejo (PARSONS; WHEATON, 2000). Koo e Hurner (1969) mostraram que irrigando após o esgotamento de um terço de depleção da água disponível no solo de Janeiro a Junho e com dois terços durante o restante do ano atingiu a maior produtividade com menor consumo de água. Durante os primeiros anos após o plantio, há geralmente uma boa realação entre aumento da lâmina de irrigação e o aumento do volume da copa e produtividade (PARSONS et al., 2001). Entretanto, árvores grandes, com excessivo crescimento induzido pela irrigação e adubação em excesso pode decrescer a produtividade por causa do sombreamento e a necessidade de poda removendo grande quantidade de material vegetativo e reprodutivo (WHEATON et al., 1991). O déficit hídrico normalmente aumenta a concentração de ${ }^{\circ}$ Brix no suco, enquanto excessiva chuva ou irrigação resulta em diluição dos açúcares ou total de sólidos solúveis no suco. Ao contrário dos açúcares, maiores níveis de irrigação normalmente aumenta o tamanho do fruto. Em muitos casos, altos níveis de irrigação na 
primavera pode aumentar o número de frutos por planta suficientemente para causar um decrescimo no tamanho dos frutos devido a uma maior carga na planta. A falta de água aumenta a espessura da casca e a relação casca-polpa, diminuindo a percentagem de suco. O défict hídrico pode reduzir o crescimento vegetativo e iniciar a indução do florescimento. Chuva ou irrigação após um período de seca pode causar um fluxo de florecismento em qualquer época do ano. Os frutos resultantes desse florescimento fora de época são usualmente de baixa qualidade na época da colheita e pode reduzir o tamanho e a qualidade da colheita principal (MORGAN, 2003). Para lima ácida 'Tahiti', Morton (1987) e Gayet et al. (1995) relataram que quando a \% de suco no fruto é entre 42 e $50 \%$, frutos estão no ponto ideal de colheita. Frutos com percentagem de suco menor que $42 \%$ não podem ser exportados para os EUA. Tais frutos podem ser exportados para Europa para específicos usos, tais como decoração em bebidas e comidas.

A produtividade média de lima ácida 'Tahiti' em São Paulo é cerca de $15 \mathrm{t} \mathrm{ha}{ }^{-1}$, muito menor que $40 \mathrm{t} \mathrm{ha}^{-1}$ produzida em pomares com irrigação e correto controle de pragas e adubação. Em Maringá, Paraná , Bertonha et al. (2004) estudaram o efeito da irrigação em laranja 'Pera' enxertada em limão 'Cravo' com taxas de irrigação de 10, 15, 20 e $25 \mathrm{~mm}$. A produção, peso médio dos frutos, produtividade, e a quantidade de sólidos solúveis produzido por planta apresentaram uma relação quadrática em função dos níveis de irrigação. A quantidade de sólidos solúveis totais do suco apresentou uma relação linear em função dos tratamentos. O peso médio dos frutos, o número de frutos, e produtividade por planta apresentaram uma relação quadrática em função da taxa de água aplicada.

Informações sobre irrigação de citros, que foram desenvolvidas em outras regiões, ou com diferentes combinações de variedades e porta-enxertos, e diferentes tipos de solo e sistemas de irrigação, não é adequado para as condições do Estado de São Paulo. Portanto, o objetivo deste trabalho é avaliar o efeito de diferentes níveis de irrigação ( 0 a $100 \%$ da evapotranspiração da cultura obtida por lisímetro de pesagem) no crescimento da copa e das raízes de plantas jovem de lima ácida 'Tahiti', produtividade e qualidade de fruto, sob irrigação por gotejamento em condições de campo. 


\subsection{Material e Métodos}

\section{Área Experimental}

O experimento foi conduzido durante um período de 3 anos (Agosto de 2002 e Maio de 2005) em uma área de aproximadamente 1,0 ha (Anexo B, Figura 1) plantada com limas ácidas 'Tahiti'(Citrus latifolia Tanaka), enxertadas em citrumelo 'Swingle' [Poncirus trifoliata (L.) Raf. $\times$ Citrus paradisi Macf.]. As plantas estavam com 1 ano de plantio no campo e espaçadas de $7 \times 4 \mathrm{~m}$, e irrigadas por 4 gotejadores autocompesáveis de $4 \mathrm{~L} \mathrm{~h}^{-1}$ (95\% de uniformidade de distribuição de água). Os gotejadores foram distribuidos de forma equidistantes entre si localizados a $0,5 \mathrm{~m}$ do tronco, formando 2 bulbos molhados em cada lado da planta. O pomar foi localizado em Piracicaba, São

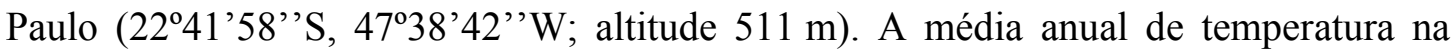
área foi de $21,4{ }^{\circ} \mathrm{C}$ e total anual de chuva foi de $1257 \mathrm{~mm}$. O solo foi um Nitossolo Vermelho (EMBRAPA, 1999), textura argilosa e 5\% de declividade média. A disponibilidade de água no solo foi de $0,125 \mathrm{~m}^{3} \mathrm{~m}^{-3}$. A média de densidade do solo medida entre $0,2 \mathrm{~m}$ e $1 \mathrm{~m}$ de profundidade foi de $1,3 \mathrm{Mg} \mathrm{m}^{-3}$. Os controles de plantas daninhas e de pragas foram realizados durante todo período experimental. O controle da adubação (Anexo A, Tabela 1) foi feito de acordo com a recomendacao de Raij et al. (1992).

$\mathrm{Na}$ área experimental (Anexo B, Figura 2), 50 plantas do mesmo tamanho foram selecionadas e divididas aleatoriamente em 5 grupos. Cada grupo foi irrigado com um diferente nível de irrigação, tratamentos baseados em ETc como segue: T1) não irrigado, T2) $25 \%$, T3) $50 \%$, T4) $75 \%$ e T5) $100 \%$ da ETc determinado por um lisímetro de pesagem (Anexo A, Tabela 2). Os níveis de irrigação foram ajustados usando diferentes números de gotejadores por planta. Em T2 $(25 \%$ ETc) um gotejador foi usado, T3 (50\% ETc) dois gotejadores, T4 $(75 \%$ ETc) três gotejadores e T5 $(100 \%$ ETc) 4 gotejadores. Os gotejadores em T2, T3 e T4 foram adaptados com divisores de descarga e microtudo (Way Multi - Outlet Dripper) para irrigar todos os tratamentos com 4 bulbos molhados (Anexo B, Figura 3). Onde T2 (25\%ETc) foi irrigado com 4 bulbos molhados de $1 \mathrm{Lh}^{-1}$, T3 (50\% ETc) com 4 bulbos molhados de $2 \mathrm{~L} \mathrm{~h}^{-1}$, T4 (75\% ETc) com 2 bulbos molhados 
de $2 \mathrm{~L} \mathrm{~h}^{-1}$ e 2 bulbos molhados de $4 \mathrm{Lh}^{-1}$ e $\mathrm{T} 5$ (100\% ETc) com 4 bulbos molhados de $4 \mathrm{~L} \mathrm{~h}^{-1}$, totalizando 4, 8, 12 e $16 \mathrm{~L} \mathrm{~h}^{-1}$ Planta $^{-1}$, em T2, T3, T4 e T5, respectivamente (Anexo B, Figura 4). O delineamento estatístico experimental utilizado foi o inteiramente casualisado, com 5 tratamentos (diferentes níveis de irrigação) e 10 repetições (uma planta cada).

\section{Medidas de Evapotranspiração}

Um lisímetro de pesagem $(2,7 \mathrm{~m}$ de diâmetro $\mathrm{x} 0,8 \mathrm{~m}$ produndidade $)$ (CAMPECHE, 2002) foi instalado no centro da área experimental com uma planta. Diferenças de massa foram monitoradas por 3 células de carga eletrônica a meia noite todos os dias quando as condições de velocidade de vento era baixa (por exemplo, média de vento $<1.5 \mathrm{~m} \mathrm{~s}^{-1}$ ) e os dados armazenados em um data logger. A exatidão das medidas foram cerca de $+/-0,25 \mathrm{~kg}$. Diariamente a evapotranspiração (ETc) foi calculada pelas variações de massa do lisímetro e convertido a $\mathrm{mm} \mathrm{dia}^{-1}$ como descrito por Folegatti et al. (2004). A planta no lisímetro foi irrigada e manejada como as demais plantas na área experimental. A evapotranspiracao de referência (ETo) foi estimada pelo modelo de Penman-Monteith (ALLEN et al., 1998). Os dados meteorológicos durante os anos em que foi conduzido o experimento foram coletados por uma estação meteorologica automática (Campbell Scientific, Logan, USA) localizada cerca de $70 \mathrm{~m}$ distante do pomar.

\section{Medidas de crescimento de planta}

$\mathrm{O}$ crescimento de planta foi avaliado mensalmente em todas as 50 plantas durante o período de Agosto de 2002 a Abril de 2005. O diâmetro do tronco foi medido a 0,05 m acima da enxertia, e a altura da árvore foi medida da superfície do solo a altura média dos galhos mais altos.

\section{Distribuição de raízes}

As raízes submetidas a diferentes níveis de irrigação foram avaliadas quando as plantas estavam com 30 meses de idade, e novamente quando as plantas estavam com 
48 meses de idade, utilizando o método descrito por Böhm (1979) e os mesmos espaçamentos de coleta de amostras adotado por Whitney et al. (1990). O delineamento experimental foi o inteiramente casualisado com 2 plantas como repetições de cada tratamento (níveis de irrigação com $0 \%, 25 \%, 50 \%, 75 \%$ e $100 \%$ de ETc). Amostras de raízes foram coletadas durante a primeira análise em 4 distâncias horizontais do tronco $(0,3,0,6,0,9$ e $1,2 \mathrm{~m})$ e 2 profundidades $(0,0-0,3$ e 0,3-0,6 m). Na segunda análise, raízes foram amostradas em 5 distâncias horizontais do tronco $(0,3,0,6,0,9,1,2$ e $1,5 \mathrm{~m})$, e 3 profundidades $(0,0-0,3,0,3-0,6$ e $0,6-0,9 \mathrm{~m})$.

As amostras de raízes foram coletadas usando um trado de boca para coletar solo, com diâmetro de $0,09 \mathrm{~m}$ e altura de $0,25 \mathrm{~m}$. As raízes foram lavadas e separadas do solo usando peneiras com $2 \mathrm{~mm}$ de abertura. Em seguida, as raízes foram secadas a $65^{\circ} \mathrm{C}$ por 72 horas e pesadas. Radicelas foram identificadas utilizando a metodologia aprasentada por Ford (1954) e Montenegro (1960), considerando radicelas, todas as raízes com diâmetro inferior a $1,5 \mathrm{~mm}$.

\section{Produtividade e qualidade de fruto}

A produtividade foi avaliada pela medida de peso e número de frutos por planta em 2004 e 2005. A qualidade da produção foi avaliada pelas medidas de diâmetro de fruto, espessura da casca, \% de suco (peso de suco por total de peso do fruto), sólidos solúveis totais, $\mathrm{pH}$ e acidez total. As colheitas foram feitas 4 vezes durante 2004 (Fevereiro, Março, Maio, Agosto), aos 18, 19, 21, 24, 32 e 38 meses após o início do experimento. Todos os frutos foram colhidos manualmente com base na coloração da casca do fruto. Os frutos foram colhidos usando o sistema brasileiro de classificação (HORTBRASIL, 2000). As duas intensidades de coloração da casca utilizados foram C3 e C4 (www.hortibrasil.org.br/classificacao/limao/arquivos/coloracao.html). Da colheita, uma sub amostra de 10 frutos por repetição foi aleatoriamente coletada para análises de qualidade de fruto. Os frutos foram lavados, colocados em sacos plástico e condicionados a $10^{\circ} \mathrm{C}$ por 12 horas. As medidas de diâmetro de fruto (equatorial), espessura da casca e \% de suco foram realizados como descrito por Bleinroth et al. (1976). Para o suco extraido, o total de sólidos solúveis ( ${ }^{\circ}$ Brix) foi medido utilizando um 
refratômetro portatil (resolução de 0,2), $\mathrm{pH}$ utilizando um potenciometro (resolução de $0,01)$, e acidez total (\%) utilizando o método da titulação, como descrito pela AOAC (1970).

\subsection{Resultados e Discussão}

\section{Crescimento de plantas}

Figura 1 (A, B, C e D) mostra a altura e diâmetro do tronco de plantas jovens de lima ácida 'Tahiti' sob diferentes tratamentos de irrigação. Após 12 e 14 meses de submissão a diferentes níveis de irrigação, a altura e diâmetro do tronco de plantas jovens mostraram uma significante diferença $(\mathrm{P}<0.05)$ entre os tratamentos (Anexo A, Tabelas 3 e 4) sem irrigação (T1) e 100\% ETc (T5). Durante Julho de 2003 a Junho de 2004, a altura média das plantas em T5 variou entre 2,63 a 3,2 m, e em T1 valores variaram entre 2,33 a 2,94 m (Figuras 1A e 1B). De Setembro de 2003 a Abril de 2005, o diâmetro do tronco em T5 variou entre 7,3 a 12,7 cm e 6,5 a 11,4 cm em T1 (Figuras $1 \mathrm{C}$ e 1D).

Estas diferenças provavelmente foram devido ao estress hídrico ocorrido (Anexo B, Figuras 5 e 6) entre Agosto e Novembro de 2002 e Março e Setembro de 2003 (Figura 2A). Os resultados deste estudo estão de acordo com Levy et al. (1978), Castel e Buj (1992). Castel (1993) mostrou que o crescimento vegetativo de plantas jovens de citrus é altamente afetado pelo estress hídrico. Maior crescimento vegetativo em plantas irrigadas, em comparação a plantas não irrigadas, também foram observadas por Castel (1993). Ele mostrou uma linear relação entre diâmetro do tronco e os níveis de irrigação.

Entre Outubro de 2002 e Abril de 2003, a taxa de crescimento do tronco (média de $0,4 \mathrm{~cm} \mathrm{mes}^{-1}$ ) foi o mais alto (Figura $1 \mathrm{~F}$ ). Este período coicidiu com a estação chuvosa onde a radiação e a temperatura do ar foram altas (Figura 3). Similarmente, a taxa de crescimento de altura de planta foi a mais alta durante Março de 2003, e este foi cerca de 4 vezes maior que a taxa de crescimento de altura de planta de Outubro de 2002 a Janeiro de 2003 (Figura 1E). Durante Novembro de 2002 e Março de 2003, o total de chuva e a média de radiação global foram $1058,3 \mathrm{~mm}$ e 593,5 $\mathrm{MJ} \mathrm{m} \mathrm{m}^{-2} \mathrm{mes}^{-1}$, 
respectivamente (Figuras 2A e 2B). Como não houve estress hídrico durante este período, os tratamentos mostraram similares taxas de crescimento de tronco e altura de planta (Figuras 1E e 1F). Portanto, durante este período, os tratamentos não mostraram diferenças significantes. Embora, a altura de planta em T5 comparado com T1 apresentou maiores valores desde o terceiro mês do início do experimento, a altura de planta em T5 não foi significativamente maior que T1 até Setembro de 2003 (Anexo A, Tabelas 3 e 4). Onde a altura de planta em T5 foi cerca de 17\% maior que T1 (Figura $1 \mathrm{~A})$. 

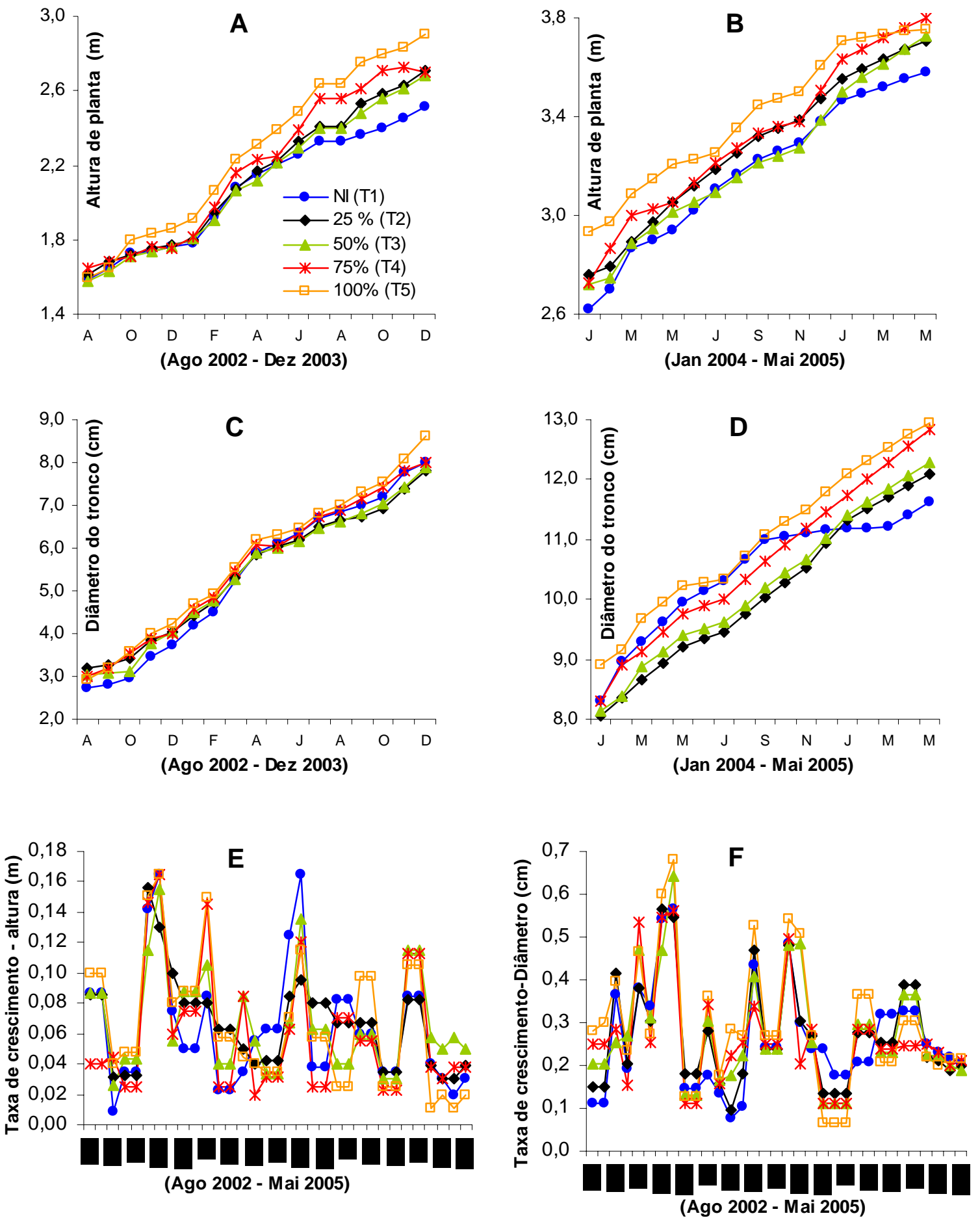

Figura 1 - Variação na altura (A, B), diâmetro do tronco (C, D), taxa de crescimento de altura (E) e diâmetro do tronco (F) em plantas de lima ácida 'Tahiti' irrigadas a $0 \%, 25 \%$, $50 \%, 75 \%$ e $100 \%$ da evapotranspiração. Pontos mostram média de 10 repetições 

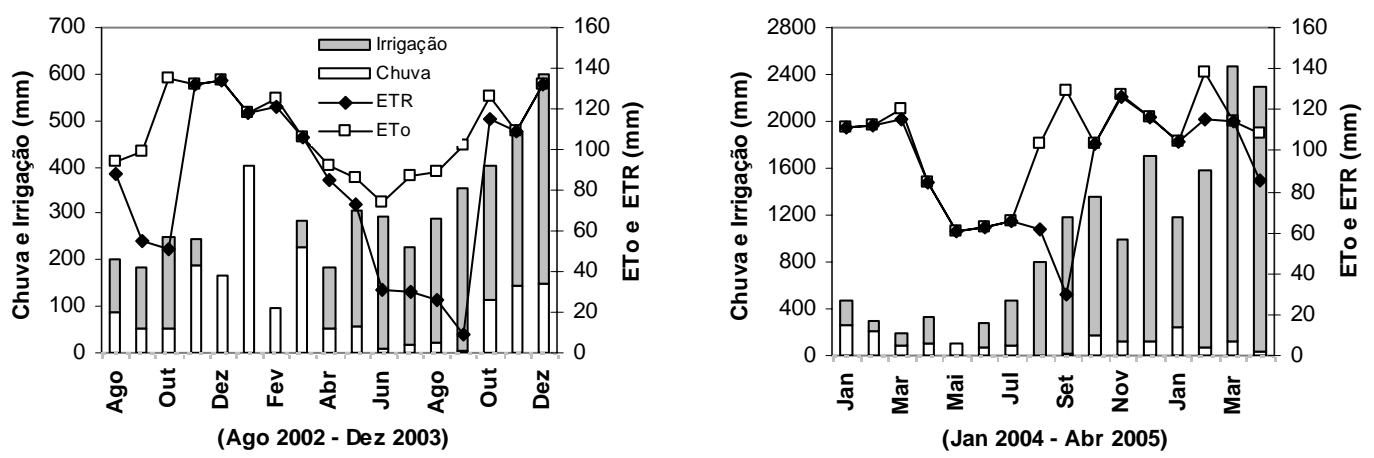

Figura 2 - Total de chuva mensal, irrigação de $100 \% E T c$, evapotranspiração de referência (ETo) e real (ETR) (Thornthwaite \& Mather, 1955) (A) e (B), durante o período experimental (Agosto de 2002 a Abril de 2005) em Piracicaba - São Paulo

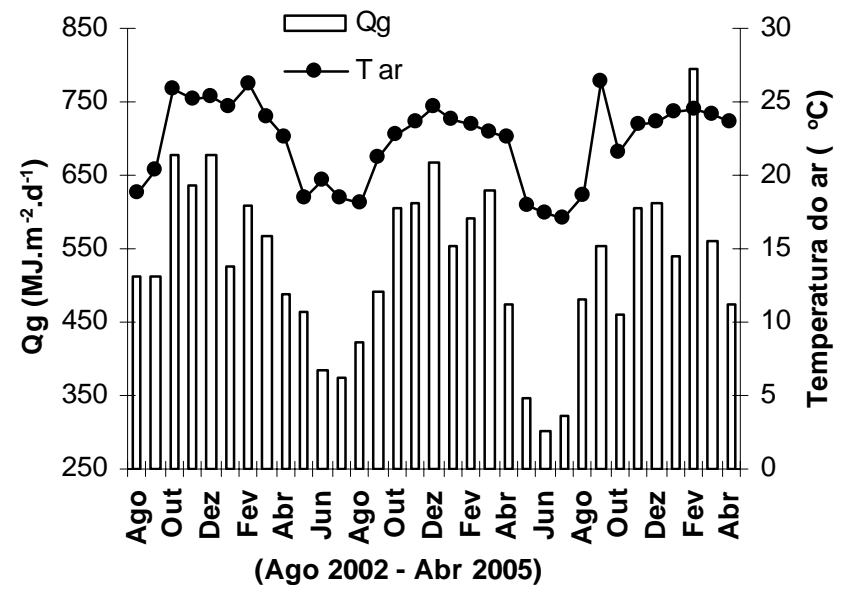

Figura 3 - Média de temperature do ar ( $\mathrm{T}$ ar) e total de radiação global mensal $(Q g)$, durante o período experimental (Agosto de 2002 a Abril de 2005) em Piracicaba - São Paulo

Os resultados sugerem que o déficit hídrico que ocorreu durante Agosto e Outubro de 2002, e Abril e Setembro de 2003 (281,1 mm de déficit acumulado em Setembro de 2003 (281,1 mm de déficit acumulado em Setembro de 2003) (Figura 2A), causou uma baixa taxa de crescimento no diâmetro do tronco e altura de planta (Figuras 1E e 1F). 
Outros estudos (CASTEL; BUJ, 1992; CASTEL, 1993) mostraram que o crescimento de plantas jovens de citros foi extremamente afetato pelo déficit hídrico durante os primeiros anos após o plantio. Castel e Buj (1992) estudou plantas jovens de tangerina 'Clementine' e observou diferenças em crescimento de plantas somente em tratamentos com níveis de irrigação menor que $40 \%$ da evaporação do Tanque Casse 'A'. Eles observaram que o melhor crescimento durante 2 anos consecutivos foi em tratamentos onde a irrigação foi $70 \%$ da evaporação do Tanque Classe 'A'. Resultados similares foram também observados por Shalhevet e Levy (1990). Castel (1994) também observou que, plantas jovens de mandarin 'Clementine de Nunes' irrigadas em 50\% ETc mostrou estress hídrico, e menor crescimento quando comparado com plantas irrigadas com $100 \%$ da ETc.

\section{Distribuição de Raízes}

Os resultados da primeira análise mostrou que houve significante diferença na distribuição de raízes entre os tratamentos $(\mathrm{P}<0.05)$ quando comparado a distribuição das raízes na direção horizontal (Tabela 1).

Tabela 1 - Análise de Variância e Teste 'F' do total de distribuição de raízes de plantas jovens (30 e 48 meses de idade) de lima ácida 'Tahiti' enxertadas em citrumelo 'Swingle', e irrigadas sob diferentes níveis de irrigação, em Piracicaba, São Paulo

\begin{tabular}{|c|c|c|c|c|}
\hline \multirow[b]{2}{*}{ Variação } & \multicolumn{2}{|c|}{ Raízes - Plantas de 30 meses } & \multicolumn{2}{|c|}{ Raízes - Plantas de 48 meses } \\
\hline & \multicolumn{4}{|c|}{ Características } \\
\hline & G.L. & $\mathbf{F}$ & G.L. & $\mathbf{F}$ \\
\hline Profundidade $(\mathrm{P})$ & 1 & $66,06 * *$ & 2 & $43,41 * *$ \\
\hline Distância Horizontal $(\mathrm{H})$ & 3 & $17,94 * *$ & 4 & $34,13 * *$ \\
\hline Níveis de Irrigação x P & 4 & $4,00 \mathrm{~ns}$ & 8 & $1,08 \mathrm{~ns}$ \\
\hline Níveis de Irrigação x H & 12 & $2,99 * *$ & 16 & $1,07 \mathrm{~ns}$ \\
\hline C. V. $(\%)$ & & 51,2 & & 54,1 \\
\hline
\end{tabular}

Liberdade; C.V. = Coeficiente de Variação. 
A Figura 4E mostra a média de distribuição de raízes no perfil do solo entre os diferentes tratamentos. Em geral, em todos os tratamentos, cerca de $79 \%\left(11,2 \mathrm{~kg} \mathrm{~m}^{-3}\right)$ das raízes foram encontradas a $0,0-0,3 \mathrm{~m}$ de profundidade, dos quais cerca de $53 \%$ $\left(5,6 \mathrm{~kg} \mathrm{~m}^{-3}\right)$ eram radicelas (diâmetro $<1,5 \mathrm{~mm}$, Figura $\left.4 \mathrm{~F}\right)$. Cerca de $21 \%\left(3,2 \mathrm{~kg} \mathrm{~m}^{-3}\right)$ de raízes foram encontradas a 0,3-0,6 $\mathrm{m}$ de profundidade (Figura 4E), das quais cerca de $77 \%\left(2,3 \mathrm{~kg} \mathrm{~m}^{-3}\right)$ eram radicelas (Figura 4F). A distribuição horizontal das raízes mostraram nenhuma diferença significativa $(\mathrm{P}<0.05)$ entre os tratametos não irrigado e irrigados com baixos níveis de irrigação (25\% e 50\% de ETc). Entretanto, estes tratamentos diferiram significativamente $(\mathrm{P}<0.05)$ quando comparado com tratamentos irrigados com os mais altos níveis de irrigação $(75 \%$ e $100 \%$ de $E T c)$. Isto mostra que raízes foram concentradas a $0,0-0,6 \mathrm{~m}$ do tronco da planta (Figura 4A e 4C). Isto foi provavelmente devido a influência da área molhada (cerca de 0,5-0,6 $\mathrm{m}$ de diâmetro de bulbo molhado) promovido por gotejadores de $4 \mathrm{Lh}^{-1}$ em T4 e $\mathrm{T} 5$ (Anexo 5). Isto mostrou que houve uma tendência das raízes se concentrarem na área molhada formada pela irrigação localizada.

Os resultados da segunda análise mostraram que não houve diferença significante entre a distribuição de raízes nos diferentes níveis de irrigação $(\mathrm{P}<0.05)$ (Tabela 1). Figura 5 mostra que em geral, $55 \%\left(9,11 \mathrm{~kg} \mathrm{~m}^{-3}\right)$ do total de raízes amostradas foram encontradas entre 0,0-0,3 m (Figura 5C). Desta quantidade cerca de 39\% eram radicelas (Figure 5D). Outros 25\% $\left(4,23 \mathrm{~kg} \mathrm{~m}^{-3}\right)$ das raízes estavam entre 0,3-0,6 $\mathrm{m}$, das quais cerca de $39 \%$ eram radicelas. Outros $20 \%\left(2,98 \mathrm{~kg} \mathrm{~m}^{-3}\right)$ das raízes estavam entre 0,6$0,9 \mathrm{~m}$ (Figura 5C), das quais cerca de 48\% eram radicelas (Figura 5D). Horizontalmente, $66 \%\left(13,0 \mathrm{~kg} \mathrm{~m}^{-3}\right)$ das raízes foram encontradas entre 0,0-0,6 $\mathrm{m}$ do tronco (Figura 5A). Deste total cerca de 33\% eram radicelas (Figura 5B). Outros 15\% $\left(2,20 \mathrm{~kg} \mathrm{~m}^{-3}\right)$ foram encontrados entre 0,6-0,9 $\mathrm{m}$ do tronco (Figura 5A), dos quais cerca de 53\% radicelas (Figure 5B). Outros $8 \%\left(1,37 \mathrm{~kg} \mathrm{~m}^{-3}\right)$ estavam entre $0,9-1,2 \mathrm{~m}$ (Figura 5A), das quais cerca de $40 \%$ eram radicelas (Figura $5 \mathrm{~B}$ ). Outros $7 \%\left(1,12 \mathrm{~kg} \mathrm{~m}^{-3}\right)$ estavam entre 1,21,5 $\mathrm{m}$ do tronco (Figura 5A), dos quais cerca de 51\% radicelas (Figura 5B). 

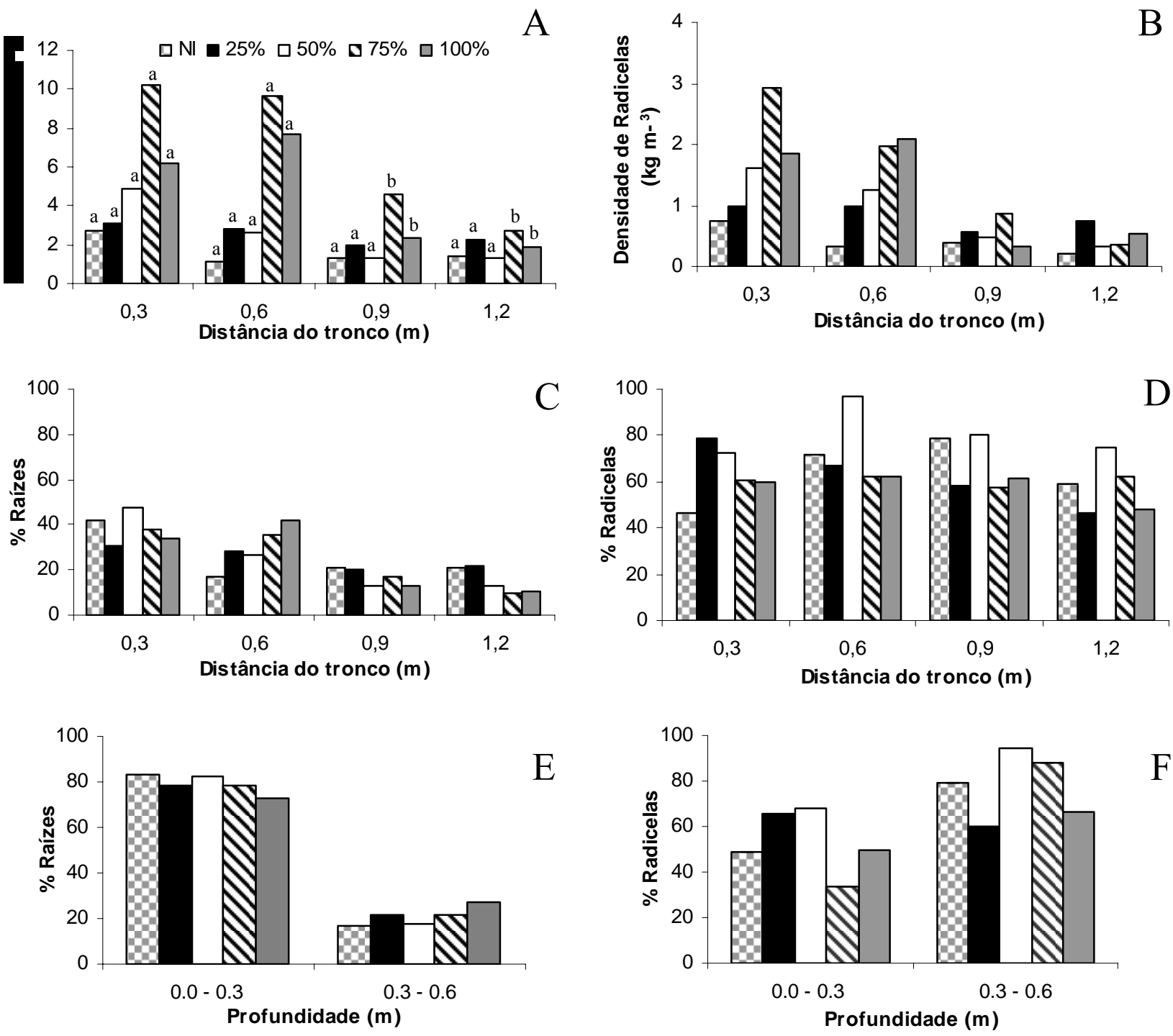

Figura 4 - Total de raízes e radicelas de plantas jovens de citrumelo 'Swingle' (30 meses de idade) distribuida horizontalmente (A, B) $\left(\mathrm{kg} \mathrm{m}^{-3}\right)$ e (C, D) (\%) e profundidade (E, F) (\%) em um perfil de solo irrigado por gotejamento. Diferentes níveis de irrigação foram 25, 50, 75 e 100\% da evapotranspiração da cultura e não irrigado (NI). Média em cada coluna com mesma letra não diferem estatisticamente ao nível de 0,05 pelo teste de Tukey. (A) Letras mostram diferenças estatísticas entre níveis de irrigação $\mathrm{x}$ distâncias horizontais do tronco 
Estes valores de distribuição de raízes estão em concordância com Montenegro (1960), Kolesnikov (1971), Moreira (1983), Santos et al. (2002), COELHO et al.(2002) e Mattos Jr. (2003).

Por exemplo, Kolesnikov (1971) e Coelho et al. (2002) observaram que raízes de citrus normalmente são concentradas horizontalmente entre 0,5 e $2 \mathrm{~m}$ do tronco da planta e entre 0 e $1 \mathrm{~m}$ de profundidade. Resultados similares foram encontrados por Montenegro (1960), o qual estudou a distribuição de raízes em diferentes porta-enxertos, observou cerca de $90 \%$ das raízes até $0,6 \mathrm{~m}$ de profundidade e até $2 \mathrm{~m}$ de distância horizontal do tronco, das quais cerca de $85 \%$ dessas raízes eram radicelas.
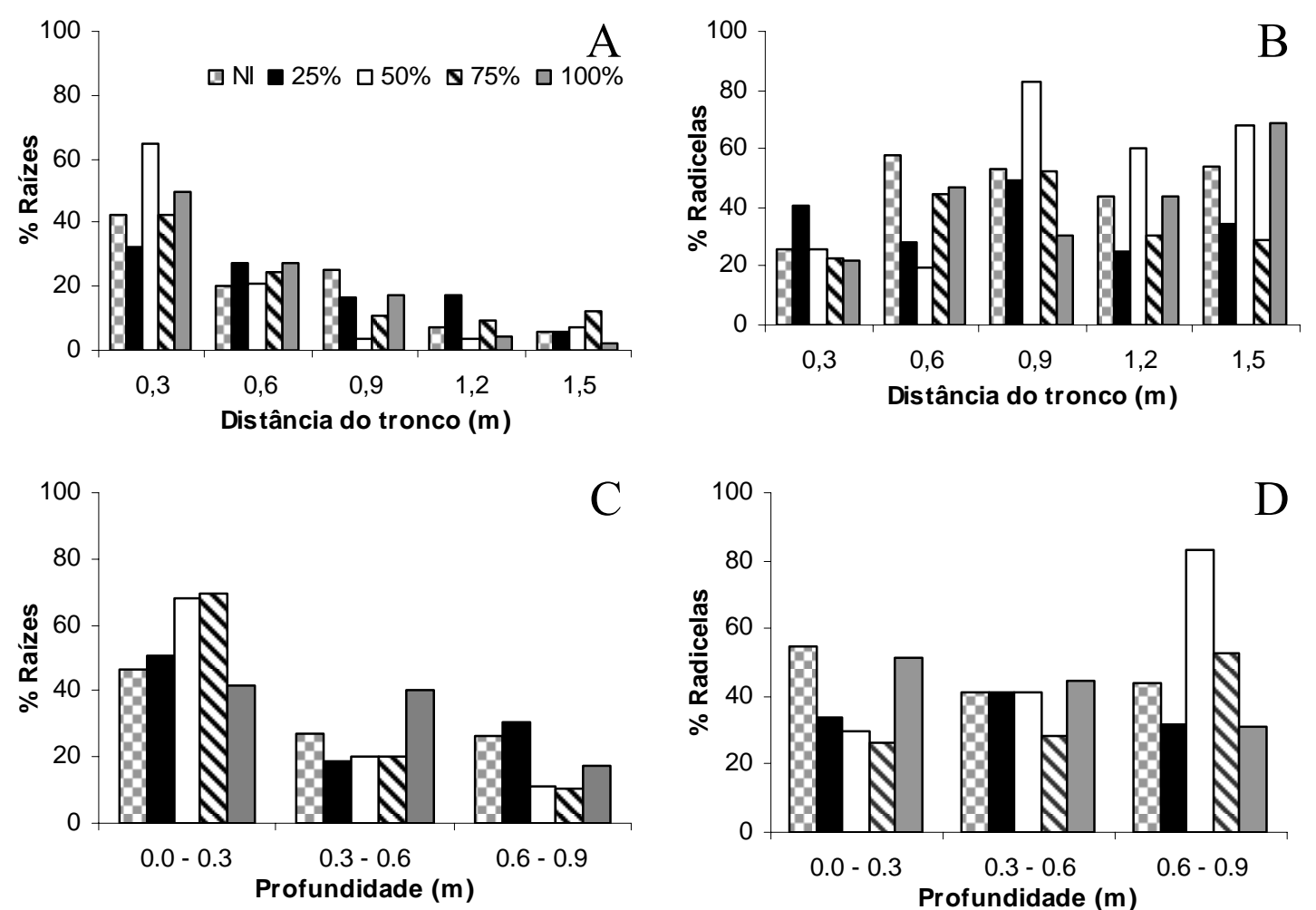

Figura 5 - Total de raízes e radicelas (\%) de plantas jovens de citrumelo 'Swingle' (48 meses de idade) distribuída horizontalmente $(\mathrm{A}, \mathrm{B})$ e profundidade $(\mathrm{C}, \mathrm{D})$ em um perfil de solo irrigado por gotejamento, sobe diferentes níveis de irrigação, 25, 50, 75 e 100\% da evapotranspiração e não irrigado (NI) 
Coelho et al. (2002) observaram que a profundidade efetiva das raízes (cerca de $80 \%$ ) de citros estavam entre 0,3 e 0,7 m. Moreira (1983) encontrou que em plantas adultas de laranja 'Baianinha' e 'Pera', a profundidade efetiva de raízes estavam a 0,6 m. Estes resultados também estão de acordo com o presente estudo. Santos et al. (2002) em um estudo com lima ácida 'Tahiti' enxertado em citrumelo 'Swingle' mostraram profundidade efetiva das raízes a $0,25 \mathrm{~m}$ de profundidade. Estes resultados foram também observados durante a primeira análise em plantas com 33 meses de idade. Mattos Jr. et al. (2003) encontraram raízes concentradas horizontalmente a uma distância de 0,5 m do tronco em plantas adultas de laranja 'Hamlin' enxertada em citrumelo 'Swingle' (6 anos de idade). Estes resultados também foram observados na segunda análise deste estudo em plantas com 4 anos de idade. Em contraste ao presente estudo, Moreira (1983), encontrou em plantas adultas de laranja 'Baianinha' e 'Pera', crescimento de raízes até 4,2 m do tronco, com um pequeno decrescimo de densidade de raízes entre 3,5 e 4,2 m. Este estudo avaliou diferente espécie, porta enxerto, idade e manejo de pomar. Isto pode explicar as diferenças, como relatado por Kolesnikov (1971).

Os resultados da primeira análise mostrou um decréscimo de densidade de raízes com o aumento da profundidade: $5,6 \mathrm{~kg} \mathrm{~m}^{-3}$ entre $0,0-0,3 \mathrm{~m} \mathrm{e} 1,15 \mathrm{~kg} \mathrm{~m}^{-3}$ entre $0,3-0,6$ m. Houve uma maior densidade de raízes em plantas irrigadas em comparação com plantas não irrigadas: $6,5 \mathrm{~kg} \mathrm{~m}^{-3}$ (T1), 10,1 $\mathrm{kg} \mathrm{m}^{-3}$ (T2), 10,2 $\mathrm{kg} \mathrm{m}^{-3}$ (T3), 27,2 $\mathrm{kg} \mathrm{m}^{-3}$ (T4), 18,1 $\mathrm{kg} \mathrm{m}^{-3}$ (T5). Estes resultados estão de acordo com os resultados encontrados por Villas Boas et al. (2002), que conduziram estudos com plantas de laranja 'Valencia'.

\section{Produtividade e qualidade de frutos}

Os resultados do primeiro ano (Tabela 2) mostram que produtividade entre os tratamentos foi diferente significante $(\mathrm{P}<0.05)$. A produtividade em T2 $(25 \%$ de ETc), T4 (75\%) e T5 (100\% de ETc) foram maiores que T1 (sem irrigação). A produtividade em T3 (50\% de ETc) foi intermediaria. Embora T5 (53 $\mathrm{kg}$ tree $\left.^{-1}\right)$ não diferiu significativamente de T2 (44 kg tree $\left.{ }^{-1}\right), \mathrm{T} 3\left(39 \mathrm{~kg}\right.$ tree $\left.^{-1}\right)$ and T4 (45 $\mathrm{kg}$ tree $\left.^{-1}\right)$, esta foi 
$22 \%$ maior. Embora T4 não foi diferente significativamente de T3, esta produtividade foi 15\% maior. Embora T3 recebeu o dobro de água de T2, este mostou 15\% menor produtividade. Embora T3 não diferiu significativamente de T1 (24 $\left.\mathrm{kg} \operatorname{tree}^{-1}\right)$, sua produtividade foi $62 \%$ maior.

Tabela 2 - Produtividade e qualidade de fruto de plantas jovens de lima ácida 'Tahiti' irrigada sob diferentes manejos de irrigação, no primeiro (2004) e segundo (2005) anos. Plantas medidas no primeiro ano (2004) estavam com 3 anos de idade e 4 anos de idade no segundo ano (2005)

\begin{tabular}{|c|c|c|c|c|c|c|c|c|c|}
\hline \multicolumn{10}{|c|}{ Primeiro ano (2004) } \\
\hline \multicolumn{2}{|c|}{ Tratamentos* } & \multirow{2}{*}{$\begin{array}{c}\text { Produtividade } \\
\text { kg planta }^{-1} \\
\end{array}$} & \multirow{2}{*}{$\begin{array}{c}\text { Frutos } \\
\mathrm{N}^{\mathrm{o}} \text {. } \text { planta }^{-1} \\
\end{array}$} & \multirow{2}{*}{$\begin{array}{c}\text { Suco } \\
\% \\
\end{array}$} & \multirow{2}{*}{$\begin{array}{c}\begin{array}{c}\text { Diâmetro } \\
\text { fruto } \\
\mathrm{mm}\end{array} \\
\end{array}$} & \multirow{2}{*}{ 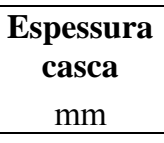 } & \multirow{2}{*}{$\begin{array}{c}\text { Acidez } \\
\% \\
\end{array}$} & \multirow[t]{2}{*}{ pH } & \multirow{2}{*}{$\begin{array}{c}\text { Sólidos } \\
\text { solúveis } \\
{ }^{\circ} \text { Brix } \\
\end{array}$} \\
\hline & & & & & & & & & \\
\hline T1 & Sem Irrigação & $24,13 \mathrm{~b}$ & $331,90 \mathrm{~b}$ & $41,93 \mathrm{a}$ & $50,42 \mathrm{a}$ & $2,67 \mathrm{a}$ & $6,57 \mathrm{a}$ & $2,61 \mathrm{a}$ & $7,97 \mathrm{a}$ \\
\hline $\mathbf{T} 2$ & $25 \% E T c$ & $44,93 \mathrm{a}$ & $644,00 \mathrm{a}$ & $43,35 \mathrm{a}$ & $50,59 \mathrm{a}$ & $2,70 \mathrm{a}$ & $6,99 \mathrm{a}$ & $2,50 \mathrm{a}$ & $8,00 \mathrm{a}$ \\
\hline T3 & $50 \% E T C$ & $39,02 \mathrm{ab}$ & $610,63 \mathrm{a}$ & $44,76 \mathrm{a}$ & $49,97 \mathrm{a}$ & $2,70 \mathrm{a}$ & $7,58 \mathrm{a}$ & $2,55 \mathrm{a}$ & $8,23 \mathrm{a}$ \\
\hline T4 & $75 \%$ ETC & $45,18 \mathrm{a}$ & $665,43 \mathrm{a}$ & $39,11 \mathrm{a}$ & $50,94 \mathrm{a}$ & $2,75 \mathrm{a}$ & $7,25 \mathrm{a}$ & $2,57 \mathrm{a}$ & $7,93 \mathrm{a}$ \\
\hline \multirow[t]{4}{*}{$\mathbf{T 5}$} & $100 \%$ ETC & $53,57 \mathrm{a}$ & $760,90 \mathrm{a}$ & $39,31 \mathrm{a}$ & $51,31 \mathrm{a}$ & $2,74 \mathrm{a}$ & $7,24 \mathrm{a}$ & $2,55 \mathrm{a}$ & $7,93 \mathrm{a}$ \\
\hline & Média & 39,96 & 575,1 & 41,69 & 50,64 & 2,58 & 7,27 & 2,56 & 7,79 \\
\hline & $D M S$ & 16,17 & 217,9 & 18,08 & 1,95 & 0,29 & 1,50 & 0,14 & 0,44 \\
\hline & C.V. & 31,83 & 29,81 & 16,13 & 1,43 & 8,97 & 12,44 & 2,08 & 2,11 \\
\hline \multicolumn{10}{|c|}{ Segundo ano (2005) } \\
\hline T1 & Sem irrigação & $28,37 \mathrm{~b}$ & $373,00 \mathrm{a}$ & $56,45 \mathrm{a}$ & $50,36 \mathrm{a}$ & $2,71 \mathrm{a}$ & $6,51 \mathrm{a}$ & $2,02 \mathrm{a}$ & $7,61 \mathrm{a}$ \\
\hline $\mathbf{T} 2$ & $25 \%$ ETC & 39,96 a & $484,00 \mathrm{a}$ & 57,58 a & 50,42 a & $2,85 \mathrm{a}$ & $6,44 \mathrm{a}$ & $2,01 \mathrm{a}$ & $7,42 \mathrm{a}$ \\
\hline T3 & $50 \% E T C$ & $35,88 \mathrm{ab}$ & $477,30 \mathrm{a}$ & $53,42 \mathrm{a}$ & $50,31 \mathrm{a}$ & $2,81 \mathrm{a}$ & $6,42 \mathrm{a}$ & $2,04 \mathrm{a}$ & $7,58 \mathrm{a}$ \\
\hline T4 & $75 \%$ ETC & $37,13 \mathrm{a}$ & $456,70 \mathrm{a}$ & $56,77 \mathrm{a}$ & $50,32 \mathrm{a}$ & $2,91 \mathrm{a}$ & $6,45 \mathrm{a}$ & $2,04 \mathrm{a}$ & $7,60 \mathrm{a}$ \\
\hline \multirow[t]{4}{*}{ T5 } & $100 \%$ ETC & $37,45 \mathrm{a}$ & $452,90 \mathrm{a}$ & $54,45 \mathrm{a}$ & $52,56 \mathrm{a}$ & $2,83 \mathrm{a}$ & $6,46 \mathrm{a}$ & $2,09 \mathrm{a}$ & $7,71 \mathrm{a}$ \\
\hline & Média & 35,76 & 448,78 & 55,73 & 50,79 & 2,82 & 6,47 & 2,04 & 7,58 \\
\hline & $D M S$ & 8,45 & 101,73 & 9,39 & 3,50 & 0,32 & 0,28 & 0,09 & 0,71 \\
\hline & C.V. & 23,93 & 22,18 & 8,95 & 3,74 & 5,98 & 2,44 & 2,44 & 4,85 \\
\hline
\end{tabular}

*: Média em cada coluna seguida de mesma letra não difere estatisticamente entre si ao nível de 0,05 pelo teste de Tukey; $C . V$. = Coeficiente de Variação; DMS = Diferença mínima significativa.

O segundo ano de produção (Tabela 2) mostrou resultados similares ao primeiro ano de produção. Plantas irrigadas tiveram de 30-40\% maior produtividade quando comparado com plantas não irrigadas. A produtividade em T2, T3, T4 e T5 diferiram 
significativamente $(\mathrm{P}<0.05)$ de $\mathrm{T} 1$. Houve nenhuma diferença significativa entre os diferentes níveis de irrigação.

Os resultados indicam a necessidade de manejo correto da irrigação, pois a cultura da lima ácida 'Tahiti' não aumenta a produtividade proporcionalmente aos diferentes níveis de irrigação. Irrigando pelo menos $25 \%$ de ETc pode-se incrementar significativamente a produtividade. Plantas irrigadas a $25 \%$ e $100 \%$ de ETc (3 anos de idade) deram produtividades que foram $86 \%$ e $122 \%$ maiores que plantas não irrigadas, respectivamente. Estes resultados estão de acordo com Vieira (1984 e 1988), Castel (1994), Duenhas et al. (2000) e Souza et al. (2003), os quais mostraram que irrigação pode incrementar a produtividade anual do citrus.

Passos et al. (1977), Marcondes (1991) e Gayet et al. (1995) observaram que lima ácida 'Tahiti' inicia uma produção econômica já a partir do terceiro ano de idade. Este estudo mostrou que irrigação também contribuiu com a precocidade da cultura. Plantas irrigadas com 3 anos de idade produziram como plantas de 5 anos não irrigadas, como relatado por Coelho (1993). Este autor mostrou que em São Paulo, a produtividade de lima ácida 'Tahiti' depende da idade da planta, por exemplo: 8-15 kg de frutos por planta aos 3 anos de idade; 23-37 kg por planta aos 4 anos de idade; 64-86 kg por planta aos 5 anos de idade e $68-141 \mathrm{~kg}$ aos 6 anos de idade.

No segundo ano de produção (plantas com 4 anos de idade), plantas irrigadas com $25 \%$ de ETc $\left(39,9 \mathrm{~kg}\right.$ planta $\left.^{-1}\right)$ mostrou $40 \%$ maior produtividade que plantas não irrigadas $\left(28,3 \mathrm{~kg} \mathrm{planta}^{-1}\right)$. Plantas irrigads aos 4 anos de idade produziram como plantas de 4 anos não irrigadas (COELHO, 1993). Isto foi provavelmente devido a característica biennial da produção de citrus, como relatado por Monselise e Goldschmidt (1982) e Forsyth (2003).

A Tabela 2 também mostrou que não houve nenhuma diferença significante $(\mathrm{P}<0.05)$ entre os níveis de irrigação quanto a qualidade de frutos entre os níveis de irrigação, tais como \% de suco, total de sólidos solúveis, $\mathrm{pH}$, acidez total, espessura da casca e diâmetro de fruto.

Normalmente, acidez é um importante fator de comercialização de lima ácida 'Tahiti'. Acidez total média (Tabela 2) encontrada neste estudo foi considerada 
aceitável, estando entre o intervalo de 6-8\% de acordo com Kefford (1959), Swisher e Swisher (1971) e Gayet et al. (1995).

Usando o sistema brasileiro de classificação (HORTBRASIL, 2000), os frutos são classificados como grupo 'A' quando a \% de suco esta entre $30-35 \%$, grupo ' $B$ ' 42 $50 \%$ e grupo ' $\mathrm{C}$ ' acima de 55\%. Portanto, a média de \% de suco neste estudo (Tabela 2) pode ser considerado dentro da categoria $\mathrm{B}$ and $\mathrm{C}$ no primeiro $(41,7 \%)$ e segundo $(55,7 \%)$ ano de produtividade, respectivamente.

O total de sólidos solúveis em lima ácida 'Tahiti' consiste principalmente de ácidos orgânicos. Normalmente, o total de sólidos solúveis é constante durante o desenvolvimento do fruto, devido ao concomitante incremento da acidez e decréscimo de açúcares (KEFFORD, 1959 e 1966). Os resultados do total de sólidos solúveis obtidos neste estudo (Tabela 2) estão entre 7 e $8{ }^{\circ}$ Brix, o qual foi considerado aceitável. Frutos estão também em ideal ponto de colheita quando estão entre $47-65 \mathrm{~mm}$ de diâmetro (GAYET et al., 1995). Usando o sistema brasileiro de classificação (HORTBRASIL, 2000), os frutos foram classificados como da Classe 50 com diâmetros entre 50-53 mm (Tabela 2).

\subsection{Conclusão}

- Plantas jovens de lima ácida 'Tahiti' irrigadas com 100\% da evapotranspiração resultou em maior crescimento em condições de campo.

- Em plantas com 33 meses de idade, a irrigação não influenciou a distribuição de raízes em profundidade. Entretanto, a irrigação influenciou na distribuição horizontal. Plantas irrigadas a 75 e $100 \%$ da evapotranspiração da cultura mostraram horizontal distribuição de raízes concentradas a $0,6 \mathrm{~m}$ do tronco.

- Em plantas com 48 meses de idade, a irrigação não teve nenhum efeito na distribuição de raízes no perfil do solo, e a efetiva ( $80 \%$ ) localização de raízes foram a $0,6 \mathrm{~m}$ de profundidade e $0,6 \mathrm{~m}$ horizontalmente distante do tronco.

- Irrigação com $25 \%$ da evapotranspiração induziu a precocidade de produção e incrementou a produtividade e o número de frutos por planta.

- Irrigação não melhorou a qualidade de fruto. 


\section{Referências}

ALVES JUNIOR, J.; LOURENÇÃO, M.S.; SILVA, T.J.A.; SILVA, C.R. Distribuição do sistema radicular de plantas jovens de lima ácida 'Tahiti' sob diferentes níveis de irrigação. Irriga, Botucatu, v. 9, n. 3, p. 270-281, 2004.

ALVES JUNIOR, J.; SILVA, C.R.; RIBEIRO, R.V.; SILVA, T.J.A.; FOLEGATTI, M.V. Growth of young 'Tahiti' acid lime trees under irrigation levels. Engenharia Agrícola, Jaboticabal, v. 25, n. 1, p. 170-178, 2005.

ALLEN, R.G.; PEREIRA, L.S.; RAES, D.; SMITH, M. Crop evapotranspiration: guindelines for computing crop water requirements. Rome: FAO, 1998. 300 p.

(Guideline, 56)

ASSOCIATION OF ANALYTICAL CHEMISTRY. Official methods of analysis of the Association of Official Analytical Chemistry. $2^{\text {nd }}$ ed. Washington, 1970. $1015 \mathrm{p}$.

BERTONHA, A.; GONÇALVES, A.C.A.; FREITAS, P.S.L., REZENDE, R. Resposta de laranjeira pêra em níveis de irrigação. Acta Scientiarum, Maringá, v. 26, n. 2, p.185$191,2004$.

BLEINROTH, W.E.; HANSEN, H.A.; FERREIRA, V.L.P.; ANGELUCCI, E.

Conservação de limões das variedades 'Thaiti' e 'Siciliano' pelo frio e com ácido giberélico. Coletânea do Instituto de Tecnologia de Alimentos, Campinas, v. 7, p. 343-70, 1976.

BÖHM, W. Methods of studying root systems. Heidelberg; Berlin: Springer-Verlag, 1979. 189 p. (Ecological Studies, 330).

BOLLER, E.F.; AVILLA J.; JÖRG, E.; MALAVOLTA, C.; WIJNANDS, F. G..; ESBJER, G.P. Integrated production: principles and technical guidelines. $3^{\text {rd }}$ ed. Bulletin IOBC/WPRS, v. 27, n. 2. Disponível em:

http://www.iobc.ch/IOBC_Citrusguideline english_definitive.pdf. Acesso em: 22 mar. 2006.

BUSTAN, A.; GOLDSCHMIDT, E.E. Estimating the cost of flowering in a grapefruit tree. Plant Cell Environmetal, Boston, v. 2, p. 217-224, 1998.

CAMPECHE, L.F.S. Construção, calibração e análise de funcionamento de lisímetros de pesagem para determinação da evapotranspiração da cultura da lima ácida 'Tahiti' (Citrus latifolia Tan.). 2002. 62 p. Tese (Doutorado em Irrigação e Drenagem) - Escola Superior de Agricultura "Luiz de Queiroz, Universidade de São Paulo, Piracicaba, 2002. 
CASTEL, J.R. Response of young Clementine citrus trees to drip irrigation. Acta Horticulturae, Leuven, n. 335, p. 313-324. 1993.

CASTEL, J.R. Response of Young clementine citrus trees to drip irrigation. I. Irrigation amount and number of drippers. Journal of Horticultural Science, Kent, v. 69, n. 3, p. 481-489, 1994.

CASTEL, J.R.; BUJ, A. Growth and evapotranspiration of young, drip-irrigated Clementine trees. Proceedings of the International Society of Citriculture, Acireale, v. 2, p. 651-656, 1992.

COELHO, E.F.; OLIVEIRA, F.C.; ARAÚJO, E.C.E.; VASCONCELOS, L.F.L. Distribuição de raízes de laranja 'Pera' sob sequeiro e irrigação por microaspersão em solo arenoso. Pesquisa Agropecuária Brasileira, Brasília, v. 37, n. 5, p. 603-61 1, 2002.

COELHO, Y.S. Lima ácida 'Tahiti’. Aspectos da produção. Brasília: EMBRAPA, SPI, 1993. 35 p. (Série Didática FRUPEX, 1).

DOOREMBOS, J.; PRUITT, W.O.. Guidelines for predicting crop water requirements. $2^{\text {nd }}$ ed. Rome: FAO, 1977. 179 p. (FAO. Irrigation and Drainage, 24).

DUENHAS, L.H.; VILLAS BOAS, R.L.; SOUZA, C.M.P.; RAGOZO, C.R.A. Efeitos da Irrigação e do modo de Aplicação de Fertilizantes na produção e qualidade de frutos de laranja (Citrus sinensis) variedade 'Valência'. In: CONGRESSO BRASILEIRO DE ENGENHARIA AGRÍCOLA, 29., 2000, Fortaleza. Anais ... Fortaleza: UFC; SBEA, 2000. 1 CD-ROM.

ESTADOS UNIDOS. Department of Agriculture. Foreing Agriculture Service. Brazil citrus: annual report 2005. Gain report BR5026. Global Agriculture Information Network. Disponivel em: http://www.fas.usda.gov/gainfiles/200512/146131807.doc Acesso em: 5 mar. 2006.

FAO. FAOSTAT statistical database. Disponível em: http://www.fao.org.com. Acesso em: 13 fev. 2003.

FNP CONSULTORIA \& AGROINFORMATIVOS. Agrianual 2003: anuário da agricultura brasileira. São Paulo, 2003. p. 295-331.

FNP COSULTORIA \& AGROINFORAMTIVOS. Agrianual 2004: anuário da agricultura brasileira. São Paulo, 2004. p. 496. 
FOLEGATTI, M.V.; ALVES JUNIOR, J.; SILVA, C. R.; SILVA, T.J.A.; CAMPECHE, L.F.S.M. Evapotranspiration of Young 'Tahiti' Lime Plants (Citrus latifolia Tan.) In: INTER REGIONAL CONFERENCE ON ENVIRONMENT AND WATER, 7., 2004, Beijing. Land and water management decision tools and practices: proceedings ... Beijing: CIGR; FAO, 2004. v. 1, p. 377-380.

FORD, H.W. Root distribution in relation to the water table. Proceedings of the Florida State for Horticultural Society, Tallahasse, v. 67, p. 30-33, 1954.

FORSYTH, J. Citrus in the garden. Agfact H 2.1.7. 2003. $4^{\text {nd }}$ ed. Disponível em http://www.agric.nsw.gov.au/reader/gr-varieties/h217.htm\#Limes Acesso em: 13 fev. 2003.

FUTCH, S.H.; BERETTA, M.J.; DERRICK, K.S.. Citrus sudden death in Brazil. Florida: University of Florida, 2005. 3 p. (IFAS Extension, HS997).

GAYET, J.P. Cultura, volheita, beneficiamiento, transporte e comercializacização de lima ácida 'Tahiti’ (Citrus latifalia Tan.) Conchal: Frutal Agrocomportadora, 1991. $42 \mathrm{p}$.

GAYET, J.P.; BLEINROTH, E.W.; MATALLO, M.; GARCIA, E.E.C.; GARCIA, A.E.; ARDITO, E.F.G.; BORDIN, M.R. Lima ácida 'Tahiti’ para exportação: procedimentos de colheita e pós-colheita. Brasília: MAARA; SDR, 1995. 36 p. (Série Publicações Técnicas Frupex, 12).

HORTIBRASIL . Brazilian Institute for Quality in Horticulture. Programa brasileiro para melhoria dos padrões comerciais e embalagens de hortigranjeiros: classificação do limão (lima ácida) 'Tahiti' (Citrus latifolia Tanaka). São Paulo: CEAGESP, 2000. 5 p.

INSTITUO BRASILEIRO DE GOGRAFIA E ESTATÍSTICA. Banco de dados agregados 2003. Disponível em: http://www.sidra.ibge.gov.br. Acesso em: 13 fev. 2003.

KEFFORD, J.K.The chemical constituents of citrus fruits. Advances in Food Research, New York, v. 9, p. 289-372, 1959

KEFFORD, J.K. Citrus fruits and processed citrus products in human nutrition. World Review of Nutrition and Dietetics, New York. v. 6, p. 197-249, 1966

KOLESNIKOV, V. The root system of fruit plant. Moscow: Mir. Publ., 1971. 255 p.

KOO, R.C.J.; HURNER JUNIORR, G.T. Irrigation requirements of citrus grown on Lakewood fine sand. Proceedings of the Florida State for Horticultural Society, Tallahasse, v. 82, p. 69-72, 1969. 
LEVY, Y.; BIELORAI, H.;SHALHEVET, J. Long-term effects of different irrigation regimes on grapefruit tree development and yield. Journal of the American Society for Horticultural Science, Alexandria, v. 103, n. 5, p. 680-683. 1978.

MARCONDES, P.T.S. Manejo do florescimento e da produção da lima ácida 'Tahiti' com reguladores de crescimento e derriça. 1991. 120 p. Dissertação (Mestrado em Fruticultura Tropical) - Escola de Agronomia, Universidade Federal da Bahia, Cruz das Almas, 1991.

MATTOS JUNIOR, D.; GRAETZ, D.A.; ALVA, A.K. Biomass Distribution and nitrogen-15 partitioning in citrus trees on a sandy entisol. Soil Science Society of America Journal, Madison, v . 67, p. 555-563, 2003.

MONSELISE, S.P.; GOLDSCHMIDT, E.E. Alternate bearing in fruit trees. Horticultural Reviews,Westport, v. 4, p. 128-173, 1982.

MONTENEGRO, H.W.S. Contribuição ao estudo do sistema radicular das plantas cítricas. 1960. 143 p. Tese (Cátedra) - Escola Superior de Agricultura "Luiz de Queiroz", Universidade de São Paulo, Piracicaba, 1960.

MOREIRA, C.S. Estudo da distribuição do sistema radicular da laranjeira Pêra (Citrus sinensis Osbeck) com diferentes manejos de solo. 1983. 97 p. Tese (Livre Docência) - Escola Superior de Agricultura "Luiz de Queiroz", Universidade de São Paulo, Piracicaba, 1983.

MORGAN, K.T. Role of irrigation on nutrient management. In: FUTCH, S.H. Nutrient management for optimum citrus tree growth and yield short course. Lake Alfred: University of Florida, IFAS Extension, 2003. p.66-81.

MORTON, J.F 'Tahiti' Lime. In: . Fruits of warm climates. 1987. p. 172-175. Disponível em: http://www.hort.purdue.edu/newcrop/morton/tahiti_lime.html. Acesso em: 10 fev. 2006.

ORTOLANI, A.A.; PEDRO JÚNIOR, M.J.; ALFONSI, R.R. Agroclimatologia e o cultivo dos citros. In: RODRIGUEZ, O.; VIÉGAS, R.; POMPEU JUNIOR, J.; AMARO, A.A.(Ed.). Citricultura brasileira. 2.ed. Campinas: Fundação Cargill, 1991. v. 1, p. 153-195.

PARSONS, L.R. Weather and irrigation for the new year. Citrus Industry, Tampa, v.1, n.1, p.16-17, Jan./Feb. 2005

PARSONS, L.R.; WHEATON, T.A Irrigation management and citrus tree response in a humid climate. HortScience, St. Joseph, v. 35, p. 1043-1045, 2000. 
PARSONS, L.R.; MORGAN, K.T.; WHEATON, T.A.;CASTLE, W.S. High application rates of reclaimed water benefit citrus tree growth and fruit production. HortScience, St. Joseph, v. 36, p. 1273-1277, 2001.

PASSOS, O.S.; COELHO, Y.S.; CUNHA SOBRINHO, A.P. Variedades de copa e porta-enxertos de citros. In: ENCONTRO NACIONAL DE CITRICULURA, 4., Aracajú, 1977. Anais... Aracajú: Sociedade Brasileira de Fruticultura, 1977. p. 21-41.

RAIJ, B. van, SILVA, N.M.; BATAGLIA, O.C.; QUAGGIO, J.A.; HIROCE, R.; CANTARELLA, H.; BELLINAZZI, J.R.; DECHEN, A.R.; TRANI, P.E.

Recomendações de adubação e calagem para o Estado de São Paulo. Campinas: IAC, 1992. 107 p. (IAC. Boletim Técnico, 100).

SANTOS, D.B.; COELHO, E.F.; SILVA, T.S.M. Distribuição espacial do sistema radicular do limão 'Tahiti' enxertado com citrumelo 'Swingle' sob microaspersão no semi árido Baiano. In: CONGRESSO BRASILEIRO DE ENGENHARIA AGRÍCOLA, 31., 2002, Salvador. Anais ... Jaboticabal: SBEA. 2002. 1 CD-ROM.

SHALHEVET, J.; LEVY, Y. Citrus trees. In: STEWART, B.A.; NIELSEN, D.R. Irrigation of agricultural crops. Madison: American Society of Agronomy; Crop Science Society of America, Soil Science Society of America, 1990. p. 951-986.

SOUZA, M.J.H.; RAMOS, M.M.; SIQUEIRA, D.L.; COSTA, L.C.; LHAMAS, A.J.M.; MANTOVANI, E.C.; CECON, P.R.; SALOMÃO, L.C.C. Produção e qualidade dos frutos da limeira ácida 'Tahiti' submetida a diferentes porcentagens de área molhada. Revista Brasileira de Engenharia Agrícola e Ambiental, Campina Grande, v. 7, n. 2, p. 245-250, 2003.

SWISHER, H.E.; SWISHER, L.H. Lemon and lime juices. In: TRAESSLER, D.K.; JOSLYN, M.A. (Ed.). Fruits and vegetable juice, processing technology. $2^{\text {nd }}$ ed. Westport: AVI, 1971. chap. 4, p.130-148.

THORNTHWAITE, C.W.; MATHER, J.R. The water balance. New Jersey: Laboratory of Climatology, 1955. 104 p. (Publications in Climatology, 8).

VIEIRA, D.B. Controle da irrigação em citricultura. Laranja, Coordeirópolis, v. 1, n. 5, p. 299-312, 1984.

VIEIRA, D.B. Fertirrigação e manejo de irrigação em citros. Laranja, Coordeirópolis, v. 2 , n. 9 , p. 369-376, 1988.

VIEIRA, D.B. Irrigação de citros. In: RODRIGUEZ, O.; VIEGAS, F.; POMPEU JUNIOR, J.; AMARO, A.A Citricultura brasileira. 2.ed. Campinas: Fundação Cargill, 1991. p.519-541. 
VILLAS BOAS, R.L.V. Teores de nutrientes na folha, qualidade do suco e massa seca de raízes de laranja 'Valência'em função da irrigação e fertirrigação. Revista Brasileira de Citricultura, Jaboticabal, v. 24, n. 1, p. 231-235, 2002.

WHEATON, T.A.; CASTLE, W.S.; WHITNEY, J.D.; TUCKER, D.P. Performance of citrus scion cultivars and rootstocks in a high density planting. HortScience, St. Joseph, v. 26, p. 837-840, 1991.

WHITNEY, J.D.; ELEZAB,Y A.; CASTLE, W. S.; WHEATON, T, A.;LITTELL, R. C.. Soil water use, root density, and fruit yield for two citrus tree spacing. Proceedings of the Florida State for Horticultural Society, Tallahasse, v. 103, p. 50-54, 1990

WRIGHT, G.C. Irrigating citrus Trees 2000. University of Arizona. College of Agriculture. Cooperative Extension. 5 p. Disponível em: cals.arizona.edu/pubs/crops/az1151.pdf. Acesso em: 05 Abr. de 2006.

ZANINI, J.R.; PAVANI, L.C. Irrigação em citros. In: SEMINÁRIO INTERNACIONAL DE CITROS, 5., 1998, Bebedouro. Anais ... Campinas: Fundação Cargill, 1998. p. 409-442. 


\section{CONCLUSÕES GERAIS}

Nas condições em que este estudo foi realizado, conclui-se que:

A independente influência da evaporação do solo e transpiração é importante para melhor entender o consumo de água de uma planta cítrica durante os primeiros estágios de desenvolvimento e em plantas adultas. Para plantas de lima ácida, o volume de água por planta calculado por $K c b+K e$ foi cerca de $80 \%$ maior que o volume calculado usando $K c$. Para plantas adultas, o volume de água por planta calculado usando somente $K c b$ pode ser $15 \%$ menor que usando somente $K c$.

- Para todas as lâminas de irrigação utilizadas $(0 \% ; 25 \% ; 50 \% ; 75 \%$ e $100 \%)$ plantas jovens de lima ácida 'Tahiti' irrigadas com 100\% da evapotranspiração resultou em maior crescimento em condições de campo.

- Em plantas com 33 meses de idade, a irrigação não influenciou a distribuição de raízes em profundidade. Entretanto, a irrigação influenciou na distribuição horizontal. Plantas irrigadas a 75 e $100 \%$ da evapotranspiração da cultura mostraram horizontal distribuição de raízes concentradas a $0,6 \mathrm{~m}$ do tronco.

- Em plantas com 48 meses de idade, a irrigação não teve nenhum efeito na distribuição de raízes no perfil do solo, e a efetiva $(80 \%)$ localização de raízes foram a $0,6 \mathrm{~m}$ de profundidade e $0,6 \mathrm{~m}$ horizontalmente distante do tronco.

- A irrigação induziu à precocidade de produção considerada comercial e ao aumento da produtividade e do número de frutos nas plantas jovens de lima ácida 'Tahiti' já a partir da lâmina de $25 \%$ da evapotranspiração da cultura, embora com grande variabilidade dos valores para essas variáveis.

- A aplicação dos níveis de irrigação de $25 \%$ a $100 \%$ da evapotranspiração da cultura não induziu às plantas jovens de lima ácida 'Tahiti' a produzirem frutos de melhor qualidade em comparação as plantas não irrigadas. 
ANEXOS 


\section{Anexo A}

Tabela 1 - Algumas propriedades químicas do solo da área experimental

\begin{tabular}{|c|c|c|c|c|c|c|c|c|c|}
\hline \multirow{2}{*}{$\begin{array}{c}\mathrm{pH} \\
\mathrm{CaCl}_{2}\end{array}$} & \multirow{2}{*}{$\begin{array}{l}\mathrm{MO} \\
\mathrm{g} \mathrm{dm}^{-3}\end{array}$} & \multirow{2}{*}{$\begin{array}{c}\mathrm{P} \\
\mathrm{mg} \mathrm{dm}^{-3}\end{array}$} & K & $\mathrm{Ca}$ & $\mathrm{Mg}$ & $\mathrm{H}+\mathrm{Al}$ & SB & $\mathrm{T}$ & $\mathrm{V}$ \\
\hline & & & \multicolumn{6}{|c|}{$\mathrm{mmol}_{\mathrm{c}} \mathrm{dm}^{-3}$} & $(\%)$ \\
\hline 5,40 & 27,00 & 43,00 & 2,70 & 41,00 & 24,00 & 34,00 & 67,70 & 101,80 & 67,00 \\
\hline
\end{tabular}

Tabela 2 - Quantidade de água recebida pelo pomar pelas chuvas e irrigações

\begin{tabular}{|c|c|c|c|c|c|c|}
\hline \multirow{2}{*}{$\begin{array}{c}\text { Plantas Idade } \\
\text { Meses }\end{array}$} & \multirow{2}{*}{$\begin{array}{l}\text { Mês/ano } \\
\text { Ago/2002 }\end{array}$} & \multirow{2}{*}{$\begin{array}{c}\begin{array}{c}\text { Chuva } \\
\text { mm mês }^{-1}\end{array} \\
18,7\end{array}$} & \multicolumn{4}{|c|}{$\begin{array}{c}\text { Irrigação (litros planta }^{-1} \text { dia }^{-1} \text { ) } \\
\text { 100\% ETc } 75 \% \text { ETc 50\% ETc 25\% ETc }\end{array}$} \\
\hline & & & 4,10 & 3,08 & 2,05 & 1,03 \\
\hline 15 & Set/2002 & 54,4 & 4,80 & 3,60 & 2,40 & 1,20 \\
\hline 16 & Out/2002 & 48,6 & 7,28 & 5,46 & 3,64 & 1,82 \\
\hline 17 & Nov/2002 & 189,0 & 2,13 & 1,60 & 1,07 & 0,53 \\
\hline 18 & Dez/2002 & 145,3 & 0,00 & 0,00 & 0,00 & 0,00 \\
\hline 19 & $\mathrm{Jan} / 2003$ & 471,3 & 0,00 & 0,00 & 0,00 & 0,00 \\
\hline 20 & Fev/2003 & 92,9 & 0,00 & 0,00 & 0,00 & 0,00 \\
\hline 21 & Mar/2003 & 226,9 & 2,06 & 1,55 & 1,03 & 0,52 \\
\hline 22 & $\mathrm{Abr} / 2003$ & 40,2 & 4,91 & 3,68 & 2,46 & 1,23 \\
\hline 23 & Mai/2003 & 21,2 & 9,08 & 6,81 & 4,54 & 2,27 \\
\hline 24 & Jun/2003 & 9,2 & 10,74 & 8,06 & 5,37 & 2,69 \\
\hline 25 & $\mathrm{Jul} / 2003$ & 18,5 & 7,61 & 5,71 & 3,81 & 1,90 \\
\hline 26 & Ago/2003 & 20,7 & 9,84 & 7,38 & 4,92 & 2,46 \\
\hline 27 & Set/2003 & 6,2 & 13,06 & 9,80 & 6,53 & 3,27 \\
\hline 28 & Out/2003 & 113,2 & 10,49 & 7,87 & 5,25 & 2,62 \\
\hline 29 & Nov/2003 & 141,3 & 12,41 & 9,31 & 6,21 & 3,10 \\
\hline 30 & Dez/2003 & 150,5 & 16,40 & 12,30 & 8,20 & 4,10 \\
\hline 31 & $\mathrm{Jan} / 2004$ & 258,1 & 7,62 & 5,71 & 3,81 & 1,90 \\
\hline 32 & $\mathrm{Fev} / 2004$ & 212,8 & 3,05 & 2,29 & 1,53 & 0,76 \\
\hline 33 & Mar/2004 & 121,1 & 3,70 & 2,78 & 1,85 & 0,93 \\
\hline 34 & $\mathrm{Abr} / 2004$ & 104,6 & 8,20 & 6,15 & 4,10 & 2,05 \\
\hline 35 & Mai/2004 & 97,2 & 0,00 & 0,00 & 0,00 & 0,00 \\
\hline 36 & Jun/2004 & 74,5 & 7,41 & 5,55 & 3,70 & 1,85 \\
\hline 37 & $\mathrm{Jul} / 2004$ & 88,4 & 14,18 & 10,63 & 7,09 & 3,54 \\
\hline 38 & Ago/2004 & 0,0 & 28,89 & 21,66 & 14,44 & 7,22 \\
\hline 39 & Set/2004 & 8,7 & 44,42 & 33,31 & 22,21 & 11,10 \\
\hline 40 & Out/2004 & 178,0 & 42,85 & 32,14 & 21,43 & 10,71 \\
\hline 41 & Nov/2004 & 115,8 & 32,83 & 24,62 & 16,41 & 8,21 \\
\hline 42 & Dez/2004 & 120,6 & 57,77 & 43,33 & 28,89 & 14,44 \\
\hline 43 & $\operatorname{Jan} / 2005$ & 240,2 & 34,65 & 25,99 & 17,33 & 8,66 \\
\hline 44 & $\mathrm{Fev} / 2005$ & 65,0 & 61,17 & 45,88 & 30,59 & 15,29 \\
\hline 45 & $\mathrm{Mar} / 2005$ & 117,4 & 85,70 & 64,28 & 42,85 & 21,43 \\
\hline 46 & $\mathrm{Abr} / 2005$ & 35,2 & 85,28 & 63,96 & 42,64 & 21,32 \\
\hline
\end{tabular}


Tabela 3 - Desenvolvimento mensal do Diâmetro do caule - valores médios em centímetros

\begin{tabular}{|c|c|c|c|c|c|c|c|c|}
\hline & $\begin{array}{c}\text { Sem } \\
\text { Irrigação }\end{array}$ & $25 \% E T c$ & $50 \%$ ETC & $75 \%$ ETC & $100 \%$ ETC & $\begin{array}{l}\text { Média } \\
\text { Geral }\end{array}$ & $D M S$ & $\mathrm{CV} \%$ \\
\hline Ago/2002 & $3,23 \mathrm{a}$ & $3,19 \mathrm{a}$ & $3,04 \mathrm{a}$ & $3,02 \mathrm{a}$ & $2,92 \mathrm{a}$ & 3,0998 & 0,4153 & 10,54 \\
\hline Set/2002 & $3,31 \mathrm{a}$ & $3,27 \mathrm{a}$ & $3,07 \mathrm{a}$ & $3,20 \mathrm{a}$ & $3,21 \mathrm{a}$ & 3,292 & 0,4404 & 10,62 \\
\hline Out/2002 & $3,40 \mathrm{a}$ & $3,43 \mathrm{a}$ & $3,12 \mathrm{a}$ & $3,48 \mathrm{a}$ & $3,59 \mathrm{a}$ & 3,4842 & 0,4656 & 10,51 \\
\hline Nov/2002 & $3,77 \mathrm{a}$ & $3,84 \mathrm{a}$ & $3,78 \mathrm{a}$ & $3,78 \mathrm{a}$ & $3,99 \mathrm{a}$ & 3,8318 & 0,4913 & 10,08 \\
\hline Dez/2002 & $3,96 \mathrm{a}$ & $4,04 \mathrm{a}$ & $4,04 \mathrm{a}$ & $3,90 \mathrm{a}$ & $4,22 \mathrm{a}$ & 4,0318 & 0,5349 & 10,44 \\
\hline Jan/2003 & $4,34 \mathrm{a}$ & $4,42 \mathrm{a}$ & $4,51 \mathrm{a}$ & $4,47 \mathrm{a}$ & $4,69 \mathrm{a}$ & 4,4029 & 0,5538 & 9,94 \\
\hline $\mathrm{Fev} / 2003$ & $4,68 \mathrm{a}$ & $4,73 \mathrm{a}$ & $4,79 \mathrm{a}$ & $4,75 \mathrm{a}$ & $4,93 \mathrm{a}$ & 4,774 & 0,5727 & 9,44 \\
\hline Mar/2003 & $5,22 \mathrm{a}$ & $5,30 \mathrm{a}$ & $5,26 \mathrm{a}$ & 5,33 a & $5,53 \mathrm{a}$ & 5,3284 & 0,6155 & 9,09 \\
\hline $\mathrm{Abr} / 2003$ & $5,79 \mathrm{a}$ & $5,84 \mathrm{a}$ & $5,90 \mathrm{a}$ & $5,96 \mathrm{a}$ & $6,21 \mathrm{a}$ & 5,9404 & 0,5929 & 7,85 \\
\hline Mai/2003 & $5,90 \mathrm{a}$ & $6,05 \mathrm{a}$ & $6,00 \mathrm{a}$ & $6,05 \mathrm{a}$ & $6,32 \mathrm{a}$ & 6,07 & 0,6205 & 8,035 \\
\hline Jun/2003 & $6,08 \mathrm{a}$ & $6,21 \mathrm{a}$ & $6,16 \mathrm{a}$ & $6,21 \mathrm{a}$ & $6 \mathrm{a}$ & 6,2038 & 0,6481 & 8,22 \\
\hline $\mathrm{Jul} / 2003$ & $6,26 \mathrm{a}$ & $6,48 \mathrm{a}$ & $6,46 \mathrm{a}$ & $6,58 \mathrm{a}$ & & 6,5234 & 0,6888 & 8,31 \\
\hline Ago/2003 & $6,39 a$ & $6,65 \mathrm{a}$ & $6,63 \mathrm{a}$ & $6,74 \mathrm{a}$ & $7,00 \mathrm{a}$ & 6,6814 & 0,668 & 7,86 \\
\hline Set/2003 & $6,47 \mathrm{~b}$ & $6,74 \mathrm{ab}$ & $6,81 \mathrm{ab}$ & $6,99 \mathrm{ab}$ & 7,29 a & 6,8584 & 0,6664 & 7,64 \\
\hline Out/2003 & $6,57 \mathrm{~b}$ & $6,92 \mathrm{ab}$ & $7,03 \mathrm{ab}$ & $7,25 \mathrm{ab}$ & $7,56 \mathrm{a}$ & 7,0664 & 0,6989 & 7,78 \\
\hline Nov/2003 & $7,01 \mathrm{~b}$ & $7,39 \mathrm{ab}$ & $7,44 \mathrm{ab}$ & $7,62 \mathrm{ab}$ & $09 \mathrm{a}$ & 7,5082 & 0,7091 & 7,43 \\
\hline Dez/2003 & $7,45 \mathrm{~b}$ & $7,81 \mathrm{~b}$ & $7,90 \mathrm{~b}$ & $8,00 \mathrm{ab}$ & & 7,9027 & 0,69495 & 6,96 \\
\hline Jan/2004 & $7,72 \mathrm{~b}$ & $8,06 \mathrm{~b}$ & $8,15 \mathrm{~b}$ & $8,30 \mathrm{ab}$ & $90 \mathrm{a}$ & 8,2972 & 0,6808 & 6,48 \\
\hline Fev/2004 & 7,97 c & $8,35 \mathrm{bc}$ & $8,39 \mathrm{bc}$ & $8,90 \mathrm{ab}$ & $9,16 \mathrm{a}$ & 8,5602 & 0,6714 & 6,17 \\
\hline Mar/2004 & $8,27 \mathrm{c}$ & $8,65 \mathrm{bc}$ & $8,87 \mathrm{bc}$ & $9,16 \mathrm{ab}$ & $9,67 \mathrm{a}$ & 8,9300 & 0,6218 & 5,47 \\
\hline $\mathrm{Abr} / 2004$ & $8,51 \mathrm{c}$ & $8,93 b$ & $9,14 \mathrm{~b}$ & $9,44 \mathrm{ab}$ & $9,94 \mathrm{a}$ & 9,1912 & 0,7016 & 5,99 \\
\hline Mai/2004 & $8,75 \mathrm{c}$ & 9,19 bc & $9,39 \mathrm{bc}$ & $9,70 \mathrm{ab}$ & $10,21 \mathrm{a}$ & 9,4524 & 0,7814 & 6,50 \\
\hline Jun/2004 & $8,93 c$ & $9,33 \mathrm{bc}$ & $9,50 \mathrm{bc}$ & $9,89 \mathrm{ab}$ & $10,28 \mathrm{a}$ & 9,5803 & 0,70875 & 5,83 \\
\hline Jul/2004 & $9,10 \mathrm{c}$ & $9,47 \mathrm{bc}$ & $9,61 \mathrm{bc}$ & $10,00 \mathrm{ab}$ & $10,34 \mathrm{a}$ & 9,7082 & 0,6361 & 5,15 \\
\hline Ago/2004 & $9,31 \mathrm{c}$ & $9,75 \mathrm{bc}$ & $9,91 \mathrm{bc}$ & $10,33 \mathrm{ab}$ & $10,71 \mathrm{a}$ & 10,0096 & 0,6554 & 5,15 \\
\hline Set/2004 & $9,61 \mathrm{c}$ & $10,02 \mathrm{bc}$ & $10,20 \mathrm{bc}$ & $10,63 \mathrm{ab}$ & $11,07 \mathrm{a}$ & 10,3110 & 0,6747 & 5,14 \\
\hline Out/2004 & $9,84 \mathrm{c}$ & $10,28 \mathrm{bc}$ & $10,43 \mathrm{bc}$ & $10,91 \mathrm{a}$ & $11,28 \mathrm{a}$ & 10,5591 & 0,67335 & 5,02 \\
\hline Nov/2004 & $10,15 \mathrm{c}$ & $10,53 \mathrm{bc}$ & $10,66 \mathrm{bc}$ & $11,18 \mathrm{ab}$ & $11,49 \mathrm{a}$ & 10,8072 & 0,6720 & 4,89 \\
\hline Dez/2005 & $10,45 \mathrm{c}$ & $10,92 \mathrm{bc}$ & $11,01 \mathrm{abc}$ & $11,32 \mathrm{ab}$ & $11,78 \mathrm{a}$ & 11,1001 & 0,6991 & 4,76 \\
\hline $\operatorname{Jan} / 2005$ & $10,80 \mathrm{c}$ & $11,31 \mathrm{bc}$ & $11,39 \mathrm{abc}$ & $11,70 \mathrm{ab}$ & $12,09 \mathrm{a}$ & 11,4603 & 0,7263 & 4,98 \\
\hline Fev/2005 & $11,01 \mathrm{c}$ & $11,51 \mathrm{bc}$ & $11,62 \mathrm{abc}$ & $12,00 \mathrm{ab}$ & $12,31 \mathrm{a}$ & 11,6902 & 0,7038 & 4,73 \\
\hline Mar/2005 & $11,21 \mathrm{c}$ & $11,70 \mathrm{bc}$ & $11,84 \mathrm{abc}$ & $12,53 \mathrm{ab}$ & $12,525 \mathrm{a}$ & 11,9070 & 0,7175 & 4,74 \\
\hline $\mathrm{Abr} / 2005$ & $11,41 \mathrm{c}$ & $11,90 \mathrm{bc}$ & $12,06 \mathrm{abc}$ & $12,55 \mathrm{ab}$ & $12,74 \mathrm{a}$ & 12,1340 & 0,7609 & 4,93 \\
\hline
\end{tabular}


Tabela 4 - Desenvolvimento mensal da altura de plantas - valores médios em metros

\begin{tabular}{|c|c|c|c|c|c|c|c|c|}
\hline Tratamento & $\begin{array}{c}\text { Sem } \\
\text { Irrigação }\end{array}$ & $25 \%$ ETc & $50 \%$ ETc & $75 \%$ ETc & $100 \%$ ETc & $\begin{array}{l}\text { Média } \\
\text { Geral }\end{array}$ & $D M S$ & $\mathrm{CV} \%$ \\
\hline Ago/2002 & $1,59 \mathrm{a}$ & $1,61 \mathrm{a}$ & $1,58 \mathrm{a}$ & $1,65 \mathrm{a}$ & $1,60 \mathrm{a}$ & 1,6198 & 0,2098 & 10,19 \\
\hline Set/2002 & $1,65 \mathrm{a}$ & $1,68 \mathrm{a}$ & $1,63 \mathrm{a}$ & $1,68 \mathrm{a}$ & $1,65 \mathrm{a}$ & 1,6727 & 0,226 & 10,61 \\
\hline Out/2002 & $1,73 \mathrm{a}$ & $1,72 \mathrm{a}$ & $1,71 \mathrm{a}$ & $1,71 \mathrm{a}$ & $1,79 \mathrm{a}$ & 1,7256 & 0,2422 & 11,04 \\
\hline Nov/2002 & $1,74 \mathrm{a}$ & $1,75 \mathrm{a}$ & $1,74 \mathrm{a}$ & $1,72 \mathrm{a}$ & $1,83 \mathrm{a}$ & 1,756 & 0,2313 & 10,36 \\
\hline Dez/2002 & $1,76 \mathrm{a}$ & $1,77 \mathrm{a}$ & $1,76 \mathrm{a}$ & $1,75 \mathrm{a}$ & $1,86 \mathrm{a}$ & 1,782 & 0,1367 & 10,7 \\
\hline $\mathrm{Jan} / 2003$ & $1,78 \mathrm{a}$ & $1,79 \mathrm{a}$ & $1,81 \mathrm{a}$ & $1,77 \mathrm{a}$ & $1,91 \mathrm{a}$ & 1,801 & 0,1617 & 9,5 \\
\hline Fev/2003 & $1,92 \mathrm{a}$ & $1,95 \mathrm{a}$ & $1,91 \mathrm{a}$ & $1,93 \mathrm{a}$ & $2,07 \mathrm{a}$ & 1,953 & 0,1868 & 7,52 \\
\hline $\mathrm{Mar} / 2003$ & $2,08 \mathrm{a}$ & $2,08 \mathrm{a}$ & $2,06 \mathrm{a}$ & $2,11 \mathrm{a}$ & $2,23 \mathrm{a}$ & 2,108 & 0,2058 & 7,68 \\
\hline $\mathrm{Abr} / 2003$ & $2,16 \mathrm{a}$ & $2,17 \mathrm{a}$ & $2,12 \mathrm{a}$ & $2,17 \mathrm{a}$ & $2,31 \mathrm{a}$ & 2,183 & 0,2125 & 7,66 \\
\hline Mai/2003 & $2,20 \mathrm{a}$ & $2,22 \mathrm{a}$ & $2,21 \mathrm{a}$ & $2,25 \mathrm{a}$ & $2,39 \mathrm{a}$ & 2,183 & 0,2125 & 7,66 \\
\hline Jun/2003 & $2,26 \mathrm{a}$ & $2,33 \mathrm{a}$ & $2,29 \mathrm{a}$ & $2,32 \mathrm{a}$ & $2,49 \mathrm{a}$ & 2,331 & 0,226 & 7,63 \\
\hline $\mathrm{Jul} / 2003$ & $2,33 \mathrm{~b}$ & $2,41 a b$ & $2,39 \mathrm{ab}$ & $2,47 \mathrm{ab}$ & $2,63 \mathrm{a}$ & 2,448 & 0,2261 & 7,27 \\
\hline $\mathrm{Ago} / 2003$ & $2,33 \mathrm{~b}$ & $2,41 \mathrm{ab}$ & $2,40 \mathrm{~b}$ & $2,47 \mathrm{ab}$ & $2,64 \mathrm{a}$ & 2,448 & 0,2261 & 7,27 \\
\hline Set/2003 & $36 \mathrm{~b}$ & $2,54 \mathrm{ab}$ & $2,48 \mathrm{~b}$ & $2,53 \mathrm{ab}$ & $2,75 \mathrm{a}$ & 2,529 & 0,2731 & 8,49 \\
\hline Out/2003 & $40 \mathrm{~b}$ & $2,59 \mathrm{ab}$ & $2,56 \mathrm{ab}$ & $2,64 \mathrm{ab}$ & $2,80 \mathrm{a}$ & 2,594 & 0,2563 & 7,77 \\
\hline Nov/2003 & $2,45 \mathrm{~b}$ & $2,63 a b$ & $2,62 \mathrm{ab}$ & $2,66 \mathrm{ab}$ & $2,84 \mathrm{a}$ & 2,636 & 0,2517 & 7,51 \\
\hline Dez/2003 & $2,51 \mathrm{~b}$ & $2,71 \mathrm{ab}$ & $2,68 \mathrm{ab}$ & $2,70 \mathrm{ab}$ & $2,90 \mathrm{a}$ & 2,727 & 0,224 & 6,51 \\
\hline Jan/2004 & $2,62 \mathrm{~b}$ & $2,76 a b$ & $2,72 \mathrm{ab}$ & $2,73 \mathrm{ab}$ & $2,93 \mathrm{a}$ & 2,772 & 0,211 & 6,01 \\
\hline Fev/2004 & $2,70 \mathrm{~b}$ & $2,79 a b$ & $2,75 \mathrm{ab}$ & $2,86 \mathrm{ab}$ & $2,97 \mathrm{a}$ & 2,817 & 0,1972 & 5,51 \\
\hline Mar/2004 & $86 \mathrm{~b}$ & $2,89 a b$ & $2,88 \mathrm{ab}$ & $2,99 \mathrm{ab}$ & $3,09 \mathrm{a}$ & 2,94 & 0,2011 & 5,37 \\
\hline $\mathrm{Abr} / 2004$ & $15 \mathrm{~b}$ & $3,03 \mathrm{ab}$ & $2,95 \mathrm{ab}$ & $2,97 \mathrm{ab}$ & $3,15 \mathrm{a}$ & 3,00 & 0,2039 & 5,35 \\
\hline Mai/2004 & $2,94 \mathrm{~b}$ & $3,01 \mathrm{ab}$ & $3,01 \mathrm{ab}$ & $3,05 \mathrm{ab}$ & $3,20 \mathrm{a}$ & 3,05 & 0,2067 & 5,33 \\
\hline Jun/2004 & $3,02 \mathrm{a}$ & $3,12 \mathrm{a}$ & $3,05 \mathrm{a}$ & $3,13 \mathrm{a}$ & $3,23 \mathrm{a}$ & 3,11 & 0,2163 & 5,47 \\
\hline $\mathrm{Jul} / 2004$ & $3,10 \mathrm{a}$ & $3,18 \mathrm{a}$ & & $3,20 \mathrm{a}$ & $3,25 \mathrm{a}$ & 3,16 & 0,2258 & 5,61 \\
\hline Ago/2004 & $17 \mathrm{a}$ & $3,25 \mathrm{a}$ & & $3,27 \mathrm{a}$ & $3,35 \mathrm{a}$ & 3,24 & 0,242 & 5,87 \\
\hline Set/2004 & $3,21 \mathrm{a}$ & $3,32 \mathrm{a}$ & $3,21 \mathrm{a}$ & $3,33 \mathrm{a}$ & $3,45 \mathrm{a}$ & 3,31 & 0,2578 & 6,13 \\
\hline Out/2004 & $3,26 \mathrm{a}$ & $3,36 \mathrm{a}$ & $3,24 \mathrm{a}$ & $3,36 \mathrm{a}$ & $3,48 \mathrm{a}$ & 3,34 & 0,2545 & 6,00 \\
\hline Nov/2004 & 3,29 a & $3,39 \mathrm{a}$ & $3,27 \mathrm{a}$ & 3,39 a & $3,50 \mathrm{a}$ & 3,36 & 0,2511 & 5,86 \\
\hline Dez/2005 & $3,33 \mathrm{a}$ & $3,44 \mathrm{a}$ & $3,41 \mathrm{a}$ & $3,55 \mathrm{a}$ & $3,62 \mathrm{a}$ & 3,47 & 0,2701 & 6,22 \\
\hline Jan/2005 & $3,46 \mathrm{a}$ & $3,55 \mathrm{a}$ & $3,50 \mathrm{a}$ & $3,62 \mathrm{a}$ & $3,71 \mathrm{a}$ & 3,75 & 0,2940 & 6,48 \\
\hline Fev/2005 & 3,49 a & $3,60 \mathrm{a}$ & $3,56 \mathrm{a}$ & $3,66 \mathrm{a}$ & $3,72 \mathrm{a}$ & 3,61 & 0,2884 & 6,29 \\
\hline Mar/2005 & $3,52 \mathrm{a}$ & $3,63 \mathrm{a}$ & $3,61 \mathrm{a}$ & $3,71 \mathrm{a}$ & $3,73 \mathrm{a}$ & 3,64 & 0,2890 & 6,26 \\
\hline $\mathrm{Abr} / 2005$ & $3,55 \mathrm{a}$ & $3,67 \mathrm{a}$ & $3,67 \mathrm{a}$ & $3,74 \mathrm{a}$ & $3,74 \mathrm{a}$ & 3,67 & 0,3035 & 6,49 \\
\hline
\end{tabular}

* Médias seguidas de mesma letra no sendido da linha , não diferem estatisticamente entre si pelo teste de Tukey a 5\% de probabilidade 
Anexo B

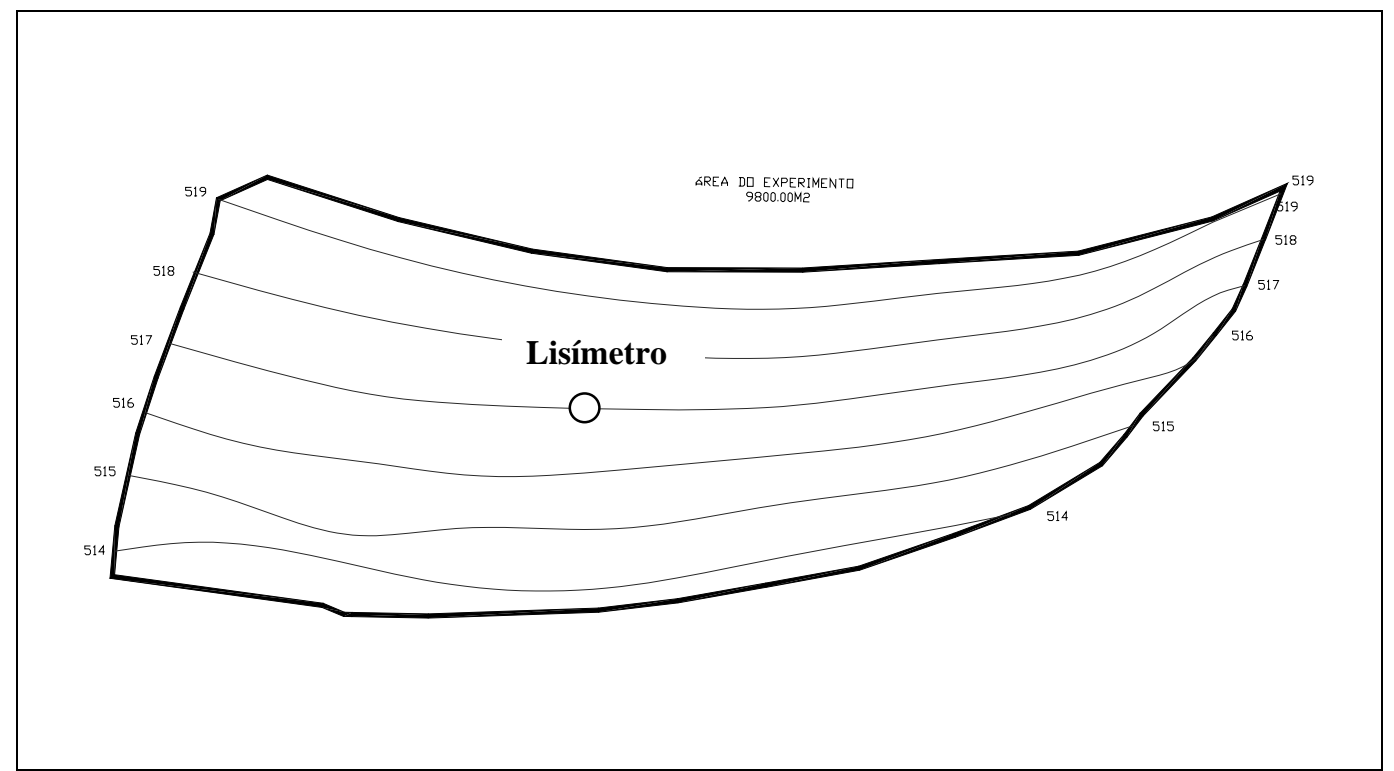

Figura 1 - Croqui geral da área, com destaque, para o local de instalação dos lisímetros e disposição das linhas de plantio

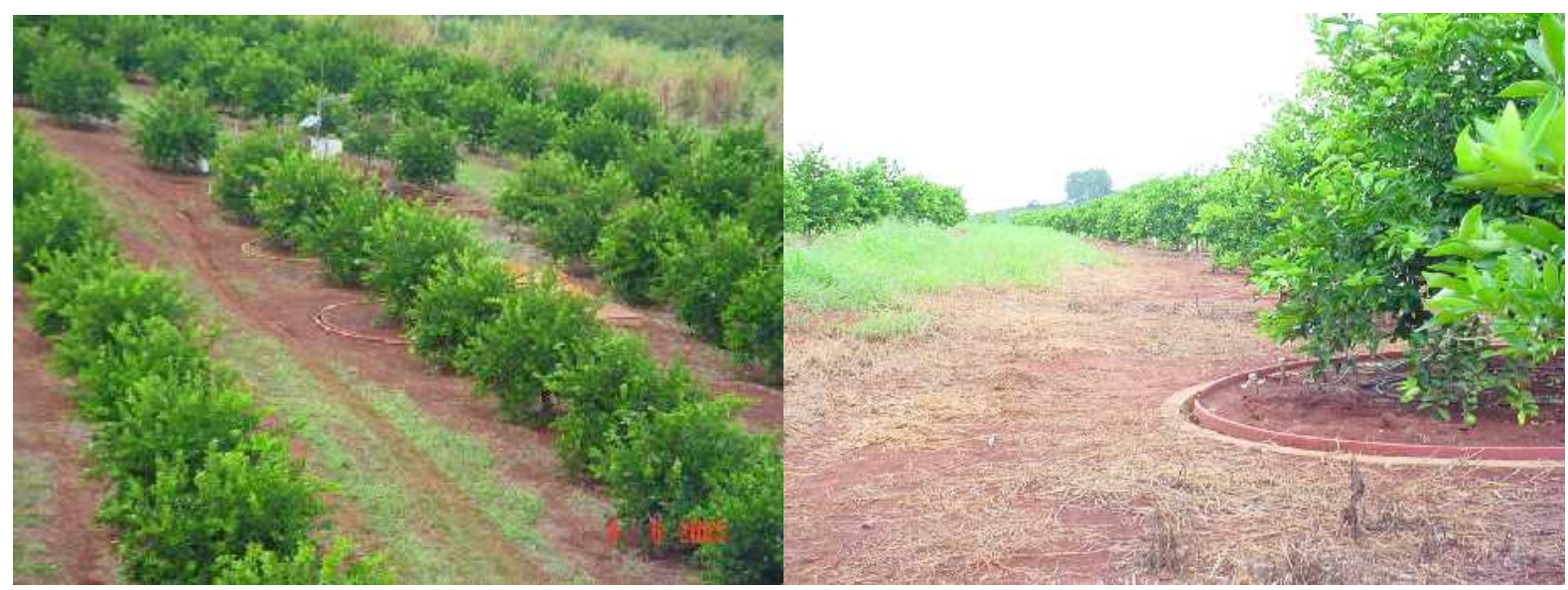

Figura 2 - Vista geral do experimento, com 24 meses, com destaque para o lisímetro com planta, estação de aquisição de dados e transmissão via rádio 


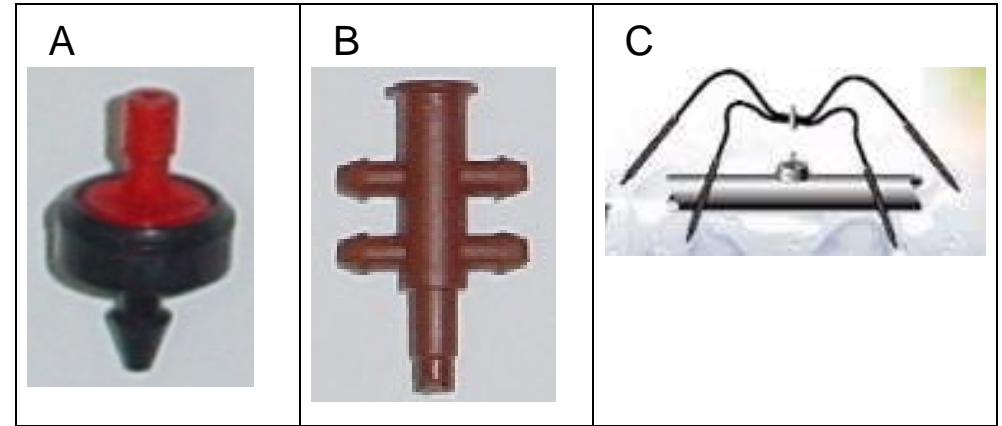

Figura 3 - (A) gotejador utilizado $\left(4\right.$ litros $\left.\mathrm{h}^{-1}\right)$; (B) distribuidor de descarga para gotejadores com saídas múltiplas; (C) esquema do distribuidor de descarga conectado a um gotejador e a micro-tubos de $3 / 5 \mathrm{~mm}$, simulando o tratamento que recebeu $25 \%$ da ETc 

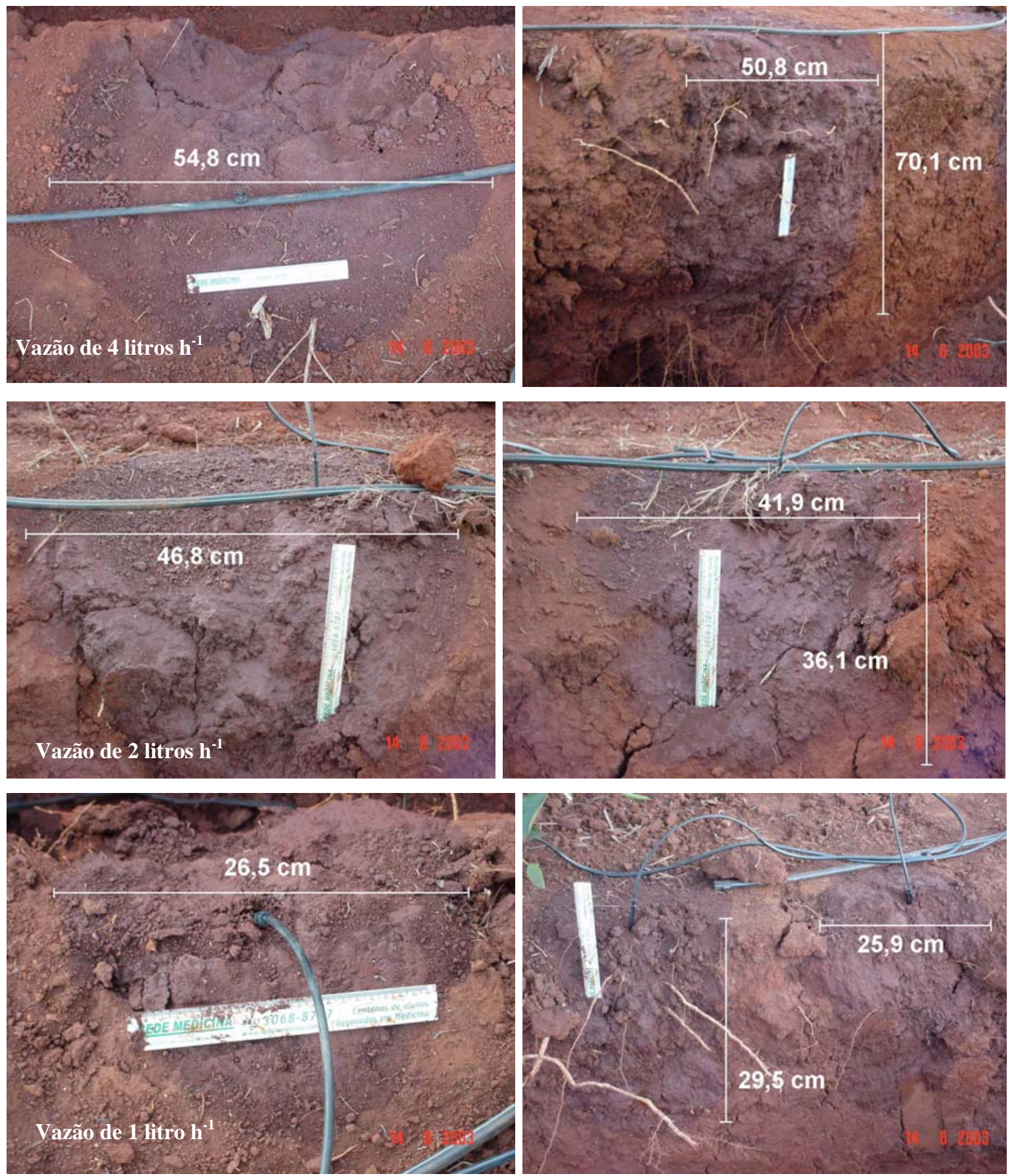

Figura 4 - Dimensões do bulbo molhado formado por gotejamento com vazões igual a 4, 2 e 1 litro por hora, com o tempo de 2 horas de irrigação em um Nitossolo Vermelho (ALVES Jr. et al., 2004) 


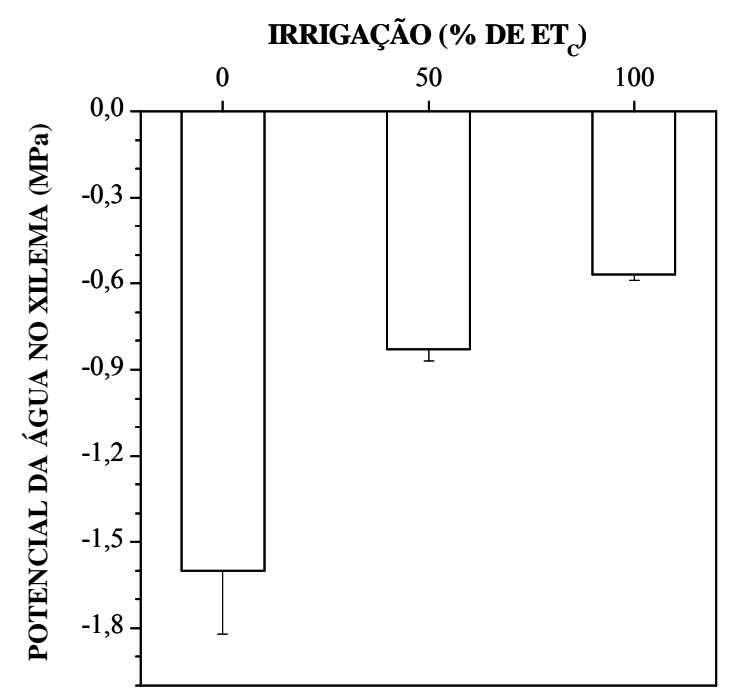

Figura 5 - Potencial de água na planta às 6 horas (Piracicaba/SP - Setembro de 2003) em limeira ácida 'Tahiti' submetida a 0, 50 e 100\% de reposição da água evapotranspirada pela cultura. Barras representam o valor médio de 10 repetições e as linhas verticais o erro padrão da média (ALVES Jr., et al. 2005) 


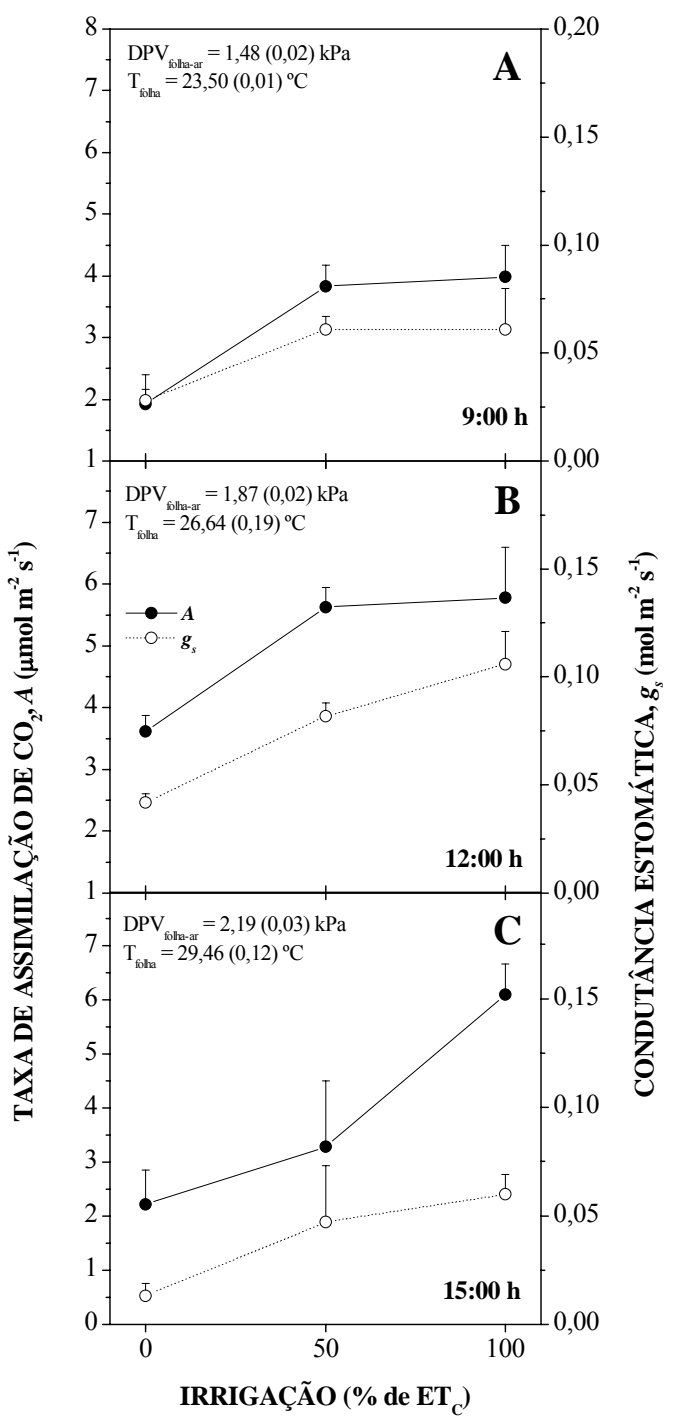

Figura 6 - Taxa de assimilação de $\mathrm{CO}_{2}$ e condutância estomática em limeira ácida 'Tahiti' submetida a 0,50 e $100 \%$ de reposição da água evapotranspirada pela cultura, medidas às 9:00 (A), 12:00 (B) e 15:00 (C) horas (Piracicaba/SP - Setembro de 2003). Pontos representam o valor médio de quatro repetições e as barras verticais o erro padrão da média. Os valores médios (erro padrão da média) da diferença de pressão de vapor folha-ar $\left(\mathrm{DPV}_{\text {folha-ar }}\right)$ e temperatura foliar $\left(\mathrm{T}_{\text {folha }}\right)$, considerando todos os tratamentos, são indicados em cada horário de medida (ALVES Jr., et al. 2005) 